\title{
25. PALYNOLOGY AND DINOCYST STRATIGRAPHY OF THE UPPER MIOCENE AND LOWERMOST PLIOCENE, ODP LEG 105, SITE 646, LABRADOR SEA ${ }^{1}$
}

\author{
Martin J. Head, ${ }^{2}$ Geoffrey Norris, ${ }^{2}$ and Peta J. Mudie $^{3}$
}

\begin{abstract}
A total of 58 productive samples have been palynologically analyzed from the upper Miocene and lowermost Pliocene of Ocean Drilling Program (ODP) Hole 646B in the central Labrador Sea. Pollen and spores are a major component of the assemblages and indicate a temperate-source vegetation, although they mainly comprise forms that are longranging in high latitudes. Reworking may account for some of these forms. A diverse marine palynoflora (70 taxa) was recovered, and five provisional dinocyst assemblage zones are erected. Palynomorph assemblages are thought to be largely allochthonous and may reflect changing bottom-water paleocurrents. The dinocyst flora consists of both oceanic and neritic species and indicates temperate surface-water conditions. Similarities exist with other dinocyst assemblages recorded from the northern North Atlantic and Norwegian Sea, although there are some important differences, including a diverse protoperidiniacean component at this site.
\end{abstract}

\section{INTRODUCTION}

Site 646 is located in the southeastern Labrador Sea at $58^{\circ}$ $12.559^{\prime} \mathrm{N}, 48^{\circ} 22.147^{\prime} \mathrm{W}$, in a water depth of $3450 \mathrm{~m}$, about $200 \mathrm{~km}$ southwest of the southern tip of the Greenland continental shelf (Fig. 1). A prominent feature of the sedimentary history of the Labrador sea is the development of extensive sediment "drift" deposits, believed to have been deposited by bottom currents during the late Cenozoic. A primary objective for drilling at Site 646 was to determine the nature and onset of drift deposition and thereby interpret the evolution of paleocurrents in this area. Site 646 is located on the northern flank of one of these drift deposits-the Eirik Ridge. This location was considered optimal for assessing the possible influence of Norwegian Sea Overflow Water (NSOW) upon drift deposition. In addition, Site 646 was chosen as part of a Leg 105 north-south transect (together with Site 647 to the south and Site 645 in Baffin Bay, to the north), the aim of which was to establish a paleoclimatic profile of this high-latitude region through the Cenozoic.

This chapter describes the palynology, and particularly the dinocyst stratigraphy, of the upper Miocene and lowermost Pliocene of Hole 646B. New taxa erected during this study are described in Head et al., (b, this volume). The Pliocene to Holocene palynostratigraphy of Hole $646 \mathrm{~B}$ is described by de Vernal and Mudie ( $a$, this volume). Ages and chronostratigraphic intervals cited here follow the time scale of Berggren et al. (1985), as agreed by the Leg 105 Scientific Party.

Preliminary palynological results of the interval studied were published in Srivastava, Arthur, et al. (1987, Site 646 chapter) and Head et al. (1986). These results were largely based on shipboard analyses of core-catcher samples, which were processed without the routine use of hydrofluoric acid because of safety reasons (see Srivastava, Arthur, et al., 1987, p. 34, for shipboard processing methods). Discrepancies arising between the preliminary studies and this shore-based investigation may have

\footnotetext{
${ }^{1}$ Srivastava, S. P., Arthur, M., Clement, B., et al., 1989. Proc. ODP, Sci. Results, 105: College Station, TX (Ocean Drilling Program).

2 Department of Geology, University of Toronto, Ontario M5S 3B1, Canada.

${ }^{3}$ Geological Survey of Canada, Atlantic Geoscience Centre, Box 1006, Dart mouth, Nova Scotia B2Y 4A2, Canada.
}

resulted from the inclusion of some caved material within the core-catcher samples during shipboard processing.

\section{Scientific Objectives}

Objectives of this study were as follows:

1. To compare the late Miocene dinoflagellate cyst assemblages of Hole 646B with published data from the Pacific, North Atlantic, and Arctic oceans and Europe to assess their stratigraphic usefulness and value as environmental indicators.

2 . To interpret the relationship between dinoflagellate assemblages and changing paleoceanographic conditions, as inferred for Hole 646B by the Leg 105 Scientific Party.

3 . To investigate the morphology and taxonomy of selected dinoflagellate cysts (see also Head et al., b, this volume).

\section{Paleoceanographic Background}

A number of important paleoclimatic and paleoceanographic events took place during the Miocene; these appear to have had a strong impact on the North Atlantic environment. These events are summarized as follows:

1. Major development of the Antarctic ice sheet during the middle Miocene, its expansion to a maximum size during the late Miocene (Shackleton and Kennett, 1975), and the consequent low stand in sea level (Haq et al., 1987) all had a profound effect on atmospheric and oceanic circulation in the Northern Hemisphere (Berggren and Olsson, 1986; Miller et al., 1987).

2. Outflow of saline water from a desiccating Mediterranean Sea ("Messinian Salinity Crisis," Hsü et al., 1977; Hodell et al., 1986) into the North Atlantic before and after the Messinian (latest Miocene) is considered to have contributed to advection of saline waters to the Norwegian-Greenland Sea and the production of North Atlantic deep waters (Stein and Bleil, 1986; Kaminski, Gradstein, Berggren, et al., this volume).

3. Change from advective, well-oxygenated North Atlantic deep water to more sluggish deep-water circulation near the Tortonian/Messinian boundary may be related to the final isolation of the Mediterranean Sea from the North Atlantic during the latest Miocene, when the outflow of saline Mediterranean water ceased (Blanc and Duplessy, 1982; Stein and Bleil, 1986). However, other evidence from studies of sediment drifts south of Ice- 


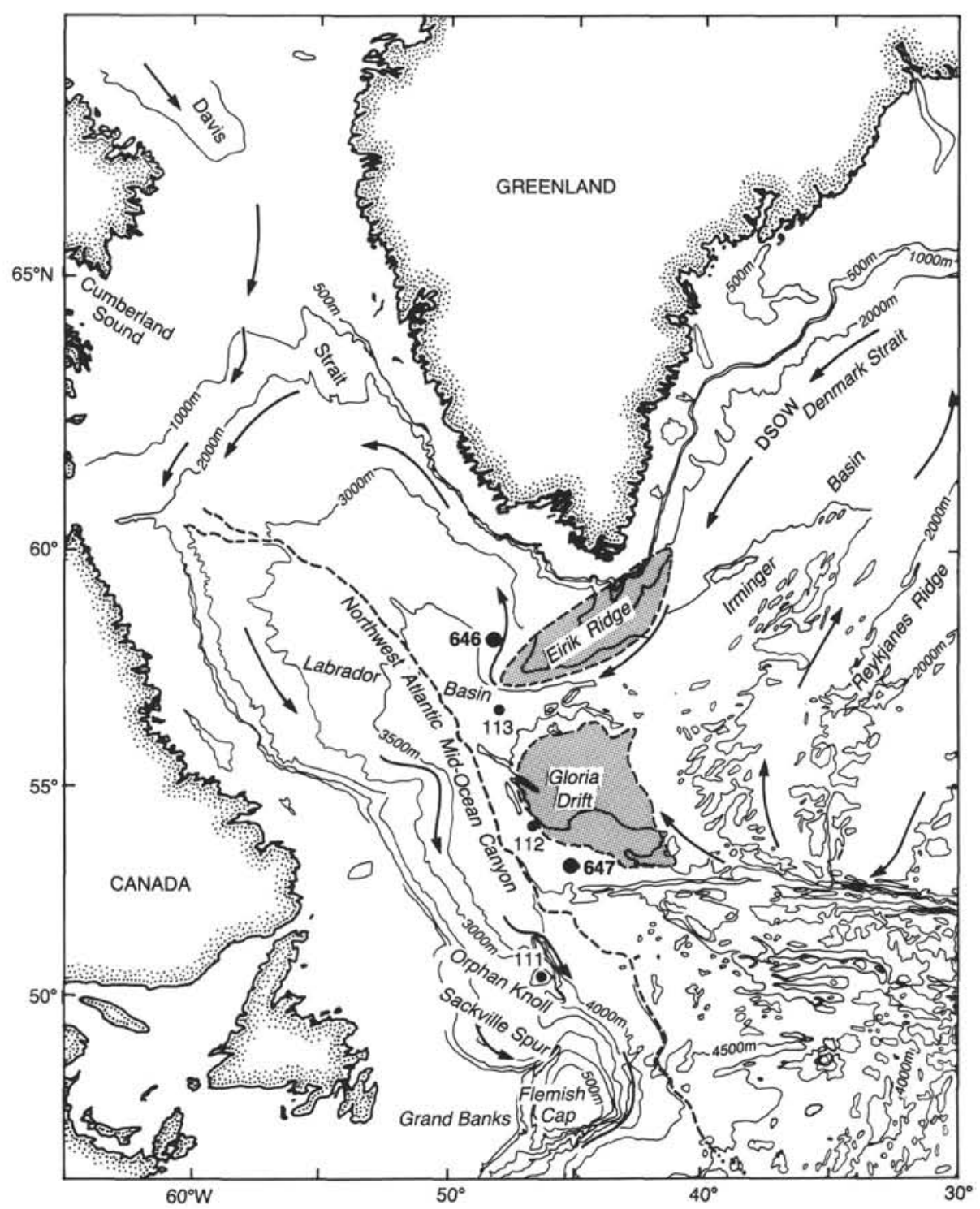

Figure 1. Location map of Site 646 and other ODP/DSDP sites, showing bathymetry of the Labrador Sea and surrounding areas, and the distribution of late Cenozoic drift deposits (shaded) and generalized modern bottom-water circulation (after McCave and Tucholke, 1986) as indicated by arrows. DSOW $=$ Denmark Strait Overflow Water.

land indicates that this event may have been accompanied by an increased flow of NSOW and bottom-sediment erosion of the high-latitude drift deposits (Kidd and Hill, 1986).

4. A significant eustatic decrease in sea level during the Messinian, caused by the buildup of the Antarctic ice sheet (Keigwin et al., 1987; Keigwin, 1987; Miller et al., 1987) led to increased erosion of landmasses and consequent influx of sediment and mineral nutrients into the North Atlantic.

5. The relatively dense Denmark Strait Overflow Water (DSOW), which presently moves south over the Greenland-Iceland Ridge and along the east coast of Greenland, hugging the continental slope and rise, and terminates as an anticlockwise gyre in the southern Labrador Sea (Gradstein and Srivastava, 1980; Kidd and Hill, 1986), was largely responsible for major drift deposition in the North Atlantic (Fig. 1). Drift deposition began during the Eocene-Oligocene in the northeast North Atlantic (Kidd and Hill, 1986) and in the early part of the late Miocene (at the R3/R4 seismic reflector) on Eirik Ridge in the Labrador Sea (Srivastava, Arthur, et al., 1987, Site 646 chap- ter). Increased activity of the DSOW near the Miocene/Pliocene boundary (Fig. 2) may have been the result of increased subsidence of the Greenland-Iceland-Faroes Ridge (Nilsen, 1983), coupled with a eustatic increase in sea level and termination of Mediterranean overflow water (Kidd and Hill, 1986) and a change in the density structure of the Norwegian-Greenland Sea, leading to the formation of denser overflow water (Kaminski, Gradstein, Berggren, et al., this volume).

6. Increased global cooling during the late Miocene may have led to the establishment of the cold, lower salinity, surface Labrador Current (Gradstein and Srivastava, 1980). This caused a progressive southward deflection of the warm Gulf Stream during the late Miocene, although this current persisted in the southern Labrador Sea until the middle late Pliocene (Berggren and Hollister, 1977; Gradstein and Srivastava, 1980; de Vernal and Mudie, a, this volume).

One might expect that some of the above events would be reflected in the composition of dinoflagellate cyst assemblages at 


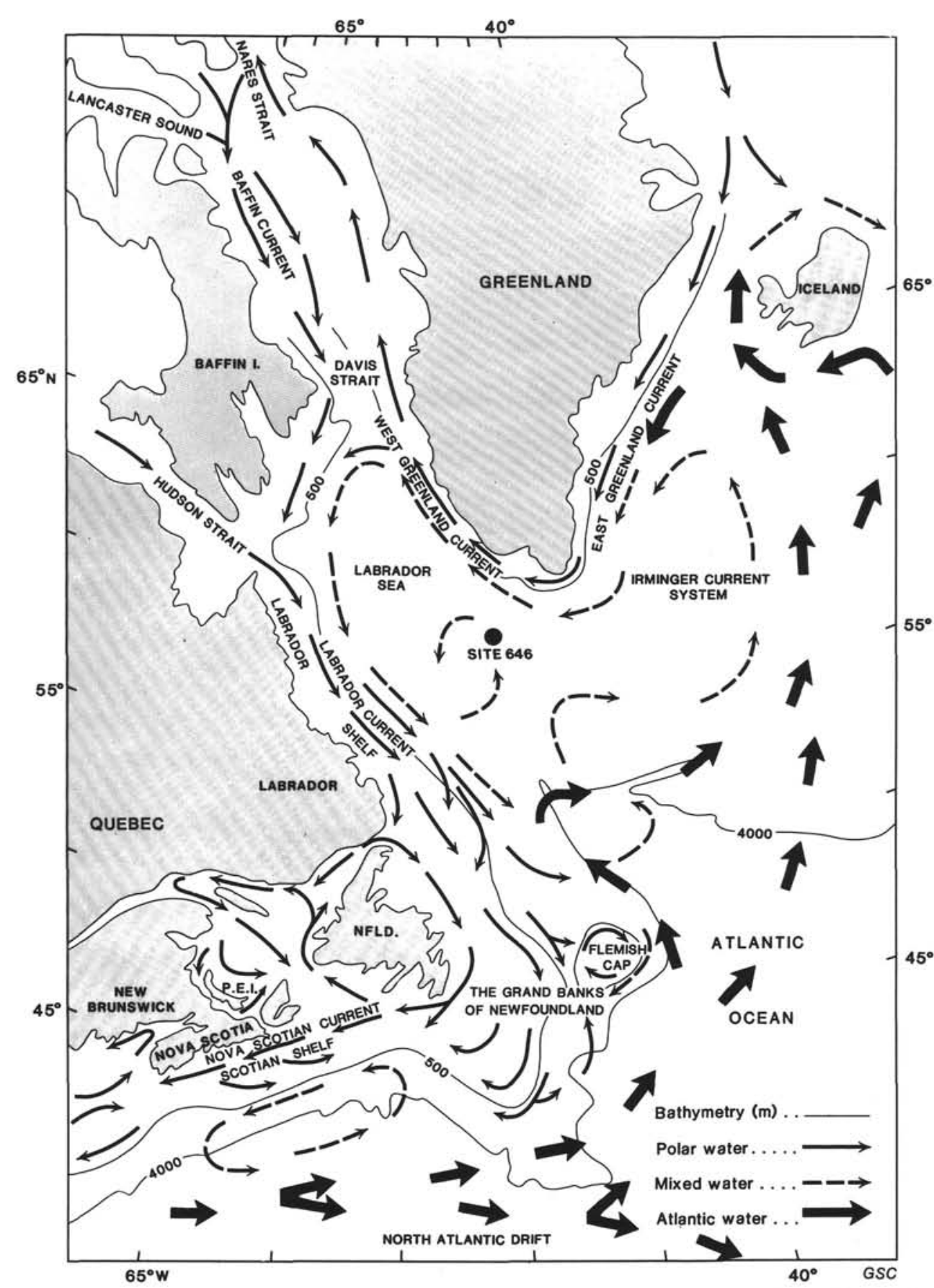

Figure 2. Distribution of modern surface currents in the western North Atlantic region (after Piper et al., in press), and location of Site 646. Broad solid arrows represent warm surface currents (Atlantic water) including and contiguous with the North Atlantic Drift; narrow broken arrows represent mixed, cool-temperate surface currents; and narrow solid arrows represent cold (polar) surface currents.

Site 646; the possible effects of these events are discussed in this study.

\section{Lithostratigraphy and Seismic Stratigraphy}

Hole 646B was drilled to a total depth of 766.7 meters below seafloor (mbsf) in a water depth of $3450 \mathrm{~m}$ and was terminated in sediments of late Miocene age (Fig. 2). The upper Miocene and lower Pliocene sediments examined are homogeneous to bioturbated silty claystone, with an interval of claystone near the base of the hole at about 720 to 735 mbsf. The upper Mio- cene sediments have a low, variable carbonate content, although this increases at about $30 \mathrm{~m}$ below the Miocene/Pliocene boundary (about 500 mbsf; Core 105-646B-53X).

Two seismic markers were identified within the interval examined here (Fig. 2; Srivastava, Arthur, et al., 1987, Site 646 chapter). The R3/R4 reflector (a reflector doublet that occurred at 680 and $730 \mathrm{mbsf}$ ) is traceable from Site 646 to across the Eirik Ridge and suggests a short hiatus, which may have been caused by erosive bottom currents. Overlying upper Miocene and lower Pliocene sediments may have been deposited by weak 
or moderate bottom currents. The $\mathrm{R} 2$ reflector occurs near the Miocene/Pliocene boundary and may be related to the slight increase in calcium carbonate within sediments just below this boundary. There is no evidence of an erosional hiatus at reflector R2. Regional seismic interpretations suggest that moderate (though not major drift-producing) bottom currents may have been a controlling factor on upper Miocene and lower Pliocene sediments occurring above the R3/R4 reflector at Site 646 (Srivastava, Arthur, et al., 1987, Site 646 chapter).

\section{METHODS}

First, samples examined by Head and Norris were cleaned (this was more difficult with smaller samples) of any adherent caved drilling "cake" and their quality assessed (Table 1). Samples $\left(10\right.$ to $20 \mathrm{~cm}^{3}$ ) were oven dried (at $70^{\circ} \mathrm{C}$, overnight), weighed, and then processed, following the method of Barss and Williams (1973), and then sieved with a 7- $\mu$ m Nitex nylon screen that was discarded after use. Two or three Stockmarr $\mathrm{Lyco}$ podium tablets were introduced at the $\mathrm{HCl}$ stage. Residues were treated briefly (about $20 \mathrm{~s}$ ) with dilute $\mathrm{HNO}_{3}$, although this was only moderately successful in removing opaque minerals. The Lycopodium spike is useful for determining if the residue has been damaged during processing and provides a means of estimating the concentration (number per gram) of dinocysts. Heavy liquid separation ( $\mathrm{ZnBr}$ S.G. 2.0) was also used on a few samples, although several cycles of centrifuging had to be performed for the "sink" fraction to release the dinocysts, which had flocculated with heavy mineral particles. Residues were stained with safranin- 0 , rinsed in deionized water, and strew mounted on $50 \times 22 \mathrm{~mm}$ coverslips using Cellosize (hydroxyethyl cellulose, batch WP-3, available from Union Carbide Corp.). The diluted Cellosize was spread across the coverslip and about six to eight drops of suspended residue were applied immediately and allowed to run across the coverslip to distribute the residue evenly. This avoided the need of using a toothpick to spread the residue, which we found caused serious flocculation of palynomorphs in our samples. Coverslips were dried slowly ( 1 or $2 \mathrm{hr}$, or more) on a slide warmer and then mounted on glass slides using Elvacite (an acrylic resin, \#2044, from DuPont Canada Inc.). Mounts for scanning electron microscopy (SEM) studies were made by air drying water-suspended residue, (re-sieved at $15 \mu \mathrm{m}$ ) onto circular glass coverslips ( $18 \mathrm{~mm}$ diameter) that were then mounted on aluminum stubs using 2-mm squares of thin, double-sided, sticky tape. Stubs were coated with gold, and a line of carbon paint was applied from the top of the coverslip (near its edge) to the aluminum stub. Seven samples were scanned. Observations and photographs were made using a JEOL 840 SEM, operating at a working voltage of 15 or $20 \mathrm{kV}$.

Samples examined by Mudie ( $8-10 \mathrm{~cm}^{3}$ volume) were processed using essentially the same method as that described above, except that light oxidation was applied using Evitt's method (1984) to remove opaque minerals and only one Lycopodium tablet per sample was used. Residues were stained with safranin-O and mounted in glycerine gel, as reported by Mudie (1987).

A total of 58 samples were processed; 32 by Head and Norris and 26 by Mudie. Usually, four slides of each sample were made, which accounted for about one-half the total residue. One slide of each sample was scanned using a Leitz Dialux (Head and Norris) or Zeiss Universal (Mudie) microscope. Abundances of individual taxa (shown in Tables 1 and 2) were estimated visually by Head and Norris, although these data may be quantified in the future using the Lycopodium spike to calculate absolute abundances. Palynomorph abundances listed in Table 3 were estimated from the samples processed and studied by Mudie. Working photomicrographs were taken with a Leitz or Zeiss polaroid attachment and Polaroid Type 667 or N55 film. England Finder coordinates are given for the location of all illustrated specimens, and in both the plate captions and text, these are preceded by the slide number shown in parentheses, which in turn is preceded by the sample number. The abbreviations for bright field (BF), interference contrast (IC), and scanning electron microscope (SEM) in the plate captions denote the microscope system used for each figure. Dimensions of figured specimens are also given in the plate captions. Transmitted light photographs (BF and IC) used for the plates were taken with a Leitz Dialux microscope fitted with a Leitz Vario-Orthomat 2 photo attachment and Ilford Pan-F film. Stratigraphic data were tabulated using the Microsoft Excel spreadsheet program on an Apple Macintosh Plus personal computer.

\section{RESULTS OF HOLE 646B}

The processing methods described above yielded clean residues for analysis. All samples were found to contain moderately to well-preserved dinocyst assemblages, although these were somewhat diluted by a greater abundance of spores and pollen, many or most of which are suspected of being reworked (Table 3 ).

\section{Reworking}

Reworked palynomorphs (in the sense of having been derived from older strata rather than having been displaced from a different but essentially coeval environment) were recognized by their flattened and/or darker appearance and by their differential (usually lower) susceptibility to staining with safranin-O (see discussion in Williams, 1978, p. 794; Mudie, in press), and by their stratigraphic discordance. Reworking of marine palynomorphs is relatively unimportant in most samples examined. Small numbers of Cretaceous dinocyst taxa (Odontochitina, Cyclonephelium, Muderongia, Cretaceous deflandreoid cysts) were recognized in most samples, as were Mesozoic-Paleocene spores. Paleocene-Eocene dinocysts were recorded occasionally and in small numbers. Nevertheless, it was difficult to determine the extent of reworking among the spore and pollen component of the assemblages, which are composed of mainly bissacate and inaperturate pollen, sphagnaceous spores (Stereisporites psilatus (Ross) Pflug, 1953 sensu lato) and triporate pollen, dominant constituents of boreal assemblages through the Paleogene and Latest Cretaceous. We suspect that a fairly large proportion of this group of sporomorphs throughout the interval studied is reworked, probably from a high-latitude $\mathrm{Pa}$ leogene source.

\section{Stratigraphy and Age of Dinocysts}

About 70 taxa of marine palynomorphs are recorded here (Tables 1 and 2), of which approximately 30 are not known from the literature. Of the remaining taxa, many have global ranges that extend into the Pliocene and Pleistocene or have been recorded infrequently elsewhere and thus have ranges that may not be applicable to this site. A small number of species forms the basis for our biostratigraphy, although a complete review of the stratigraphic occurrences of most taxa is included in the "Systematics" section (this chapter). The upper Miocene to lowermost Pliocene interval described here has good biostratigraphic control, based on calcareous nannofossils (nannofossil Zones NN11 to NN12) and planktonic foraminifers (Tables 1 and 2); also Aksu and Kaminski, this volume; Knüttel et al., this volume) and magnetostratigraphy (Clement et al., this volume). This interval represents almost continuous sedimentation from about 5 to $9 \mathrm{Ma}$, with the exception of a short hiatus of $0.5 \mathrm{Ma}$ or a change in sedimentation rate, (Srivastava, Arthur, et al., 1987) at about 7.4 Ma, which corresponds to the seismic reflector doublet R3/R4 (at 680 and 730 mbsf).

Five provisional dinocyst assemblage zones (HNM1 to HNM5) are proposed here and defined below in ascending stratigraphic order, together with their age justification (based on dinocysts alone) and with respective ages, as determined by the Leg 105 Scientific Party (see Tables 1 and 2). More detailed sampling of the studied interval will be necessary to refine this biostratigraphic breakdown based on dinocysts.

We did not erect a formal biostratigraphic zonation for dinoflagellates at Site 646 , as there is not enough detailed information about paleoecology and provincialism of many taxa encountered in this study for us to be certain of their precise stratigraphic use in other sections. This uncertainty is supported because no single standard dinoflagellate zonation exists for the late Cenozoic. Nevertheless, we are optimistic that a number of 
Table 1. Range chart showing stratigraphic distribution of marine palynomorph species recorded for the Miocene and lowermost Pliocene of Hole 646B, primarily ordered by ascending lowest occurrences.

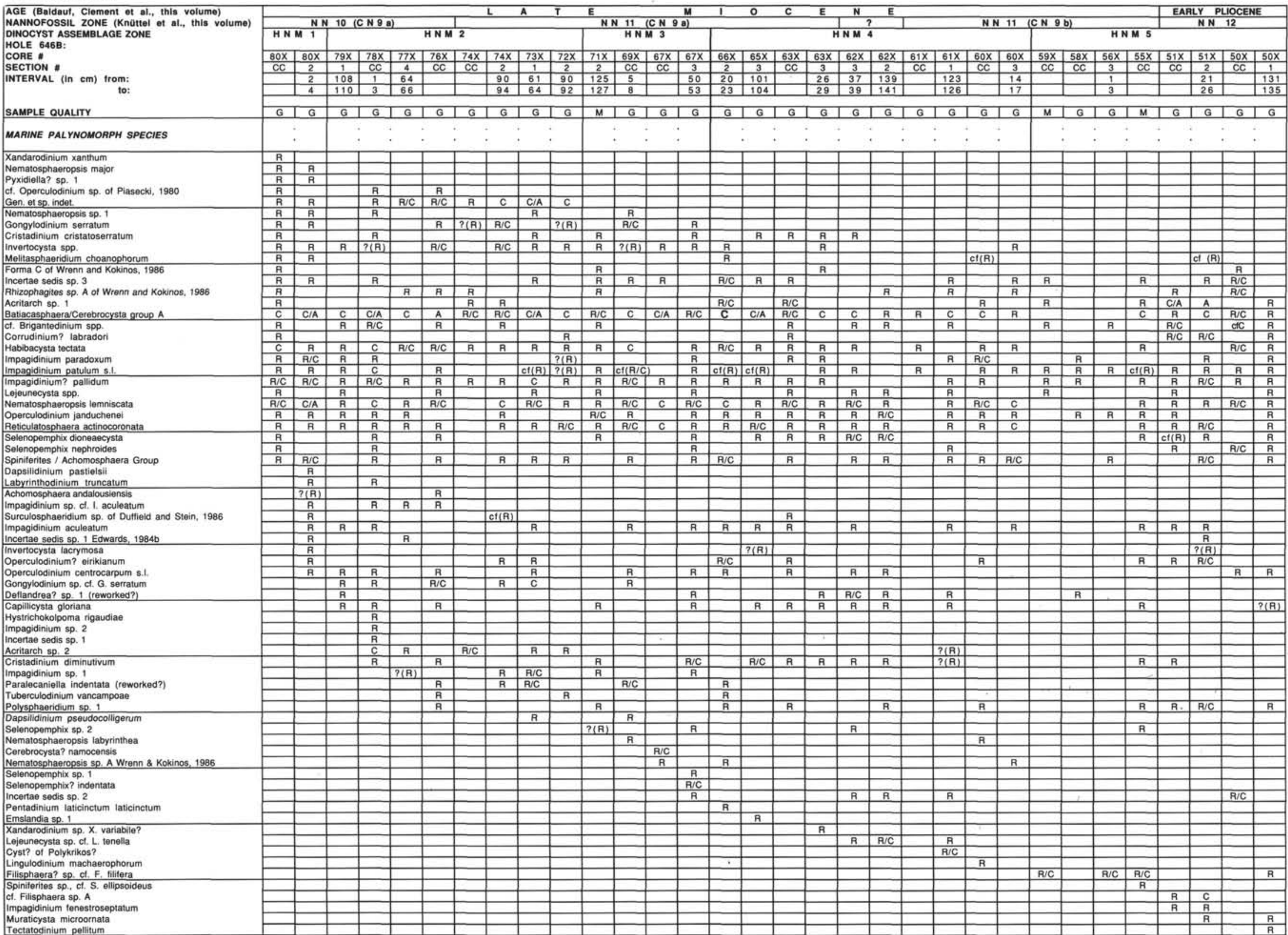

Note: Dinocyst assemblage zones (HNM1 through HNM5) are from this paper, nannofossil zones are from Knüttel et al. (this volume), and age is from the Leg 105 Shipboard Party, using the geochronology of Berggren et al. (1985). The letters R, C, and A on the range chart indicate rare, common, and abundant, respectively, and record visual estimates of the abundance of taxa in each sample. Sample quality is indicated by the symbols $\mathrm{G}$ (good quality - no contamination) and $\mathrm{M}$ (medium quality-probable slight contamination from drilling slurry). 
Table 2. Range chart showing stratigraphic distribution of marine palynomorph species recorded for the Miocene and lowermost Pliocene of Hole 646B, primarily ordered by ascending highest occurrences.

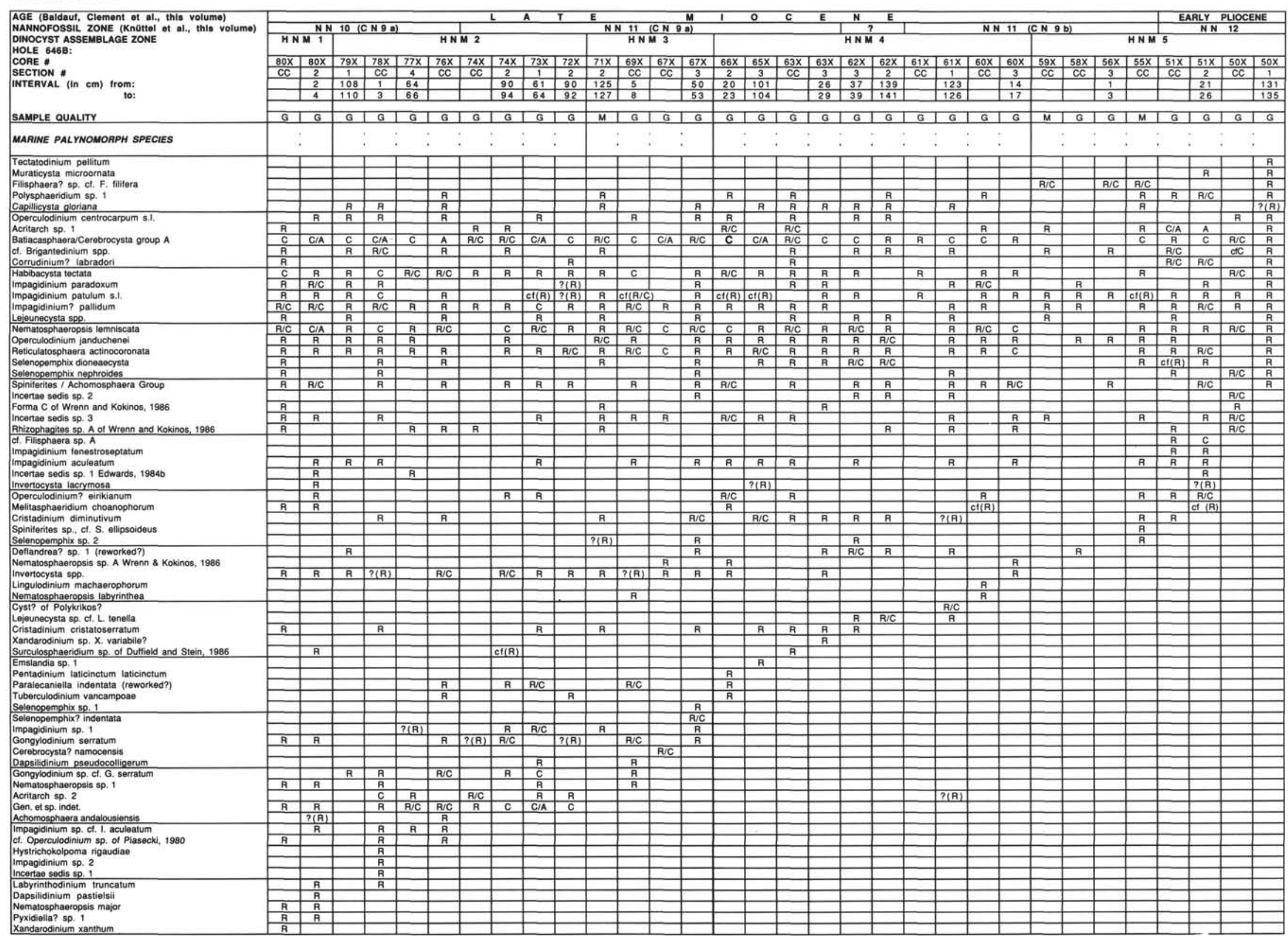

Note: Dinocyst assemblage zones (HNM1 through HNM5) are from this paper, nannofossil zones are from Knüttel et al. (this volume), and age is from the Leg 105 Shipboard Party, using the geochronology of Berggren et al. (1985). The letters R, C, and A on the range chart indicate rare, common, and abundant, respectively, and record visual estimates of the abundance of taxa in each sample. Sample quality is indicated by the symbols $\mathrm{G}$ (good quality-no contamination) and $\mathrm{M}$ (medium quality - probable slight contamination from drilling slurry). 
Table 3. Quantitative data for dinocysts, pollen, spores, and other acidresistant microfossils in organic residues from upper Miocene sediments of Hole 646B.

\begin{tabular}{|c|c|c|c|c|c|c|}
\hline \multirow{2}{*}{$\begin{array}{l}\text { Core, section, } \\
\text { interval }(\mathrm{cm})\end{array}$} & \multicolumn{6}{|c|}{ Palynomorphs (number/g) } \\
\hline & DINO & P-S & ACRI & BS & FORAM & DR \\
\hline 105-646B-56X-1, 7-10 & 1075 & 606 & 469 & 0 & 0 & 332 \\
\hline $56 X-2,17-20$ & 659 & 311 & 286 & 0 & 0 & co \\
\hline $56 \mathrm{X}-3,20-23$ & 1267 & 467 & 100 & 0 & 0 & a \\
\hline $60 \times-1,135-139$ & 9533 & 5200 & 5000 & 0 & 0 & a \\
\hline $60 \times-2,45-49$ & 535 & 214 & 100 & 764 & 0 & $\mathrm{r}$ \\
\hline $60 \mathrm{X}-1,100-103$ & 2600 & 2600 & 25 & 0 & 0 & a \\
\hline $60 X-1,66-70$ & 867 & 288 & 343 & 6500 & 0 & co \\
\hline $62 X-2,19-23$ & 1182 & 522 & 522 & 0 & 0 & co \\
\hline $62 X-3,18-21$ & 1024 & 394 & 450 & 2600 & 0 & co \\
\hline $62 X-4,6-10$ & 89 & 17 & 8 & 0 & 0 & co \\
\hline $62 X-5,18-20$ & 249 & 47 & 40 & 510 & 0 & co \\
\hline $63 \mathrm{X}-1,46-50$ & 92 & 57 & 11 & 0 & 0 & co \\
\hline $63 X-3,14-16$ & 200 & 26 & 500 & 0 & 0 & co \\
\hline $65 X-2,54-59$ & 484 & 179 & 20 & 0 & 0 & co \\
\hline $65 X-3,5-8$ & 280 & 171 & 54 & 0 & 0 & $\mathrm{r}$ \\
\hline $65 X-4,7-11$ & 83 & 83 & 10 & 4000 & 0 & co \\
\hline $66 \mathrm{X}-1,11-15$ & 902 & 75 & 30 & 3750 & 10 & $\mathrm{r}$ \\
\hline $67 X-1,12-16$ & 296 & 129 & 13 & 8100 & 250 & co \\
\hline $67 X-2,3-7$ & 520 & 1820 & 1000 & 4160 & 0 & $\mathrm{r}$ \\
\hline $67 X-3,11-15$ & 64 & 193 & 10 & 1300 & 0 & a \\
\hline $67 X-4,0-4$ & 313 & 439 & 31 & 0 & 0 & co \\
\hline $67 X-5,13-15$ & 177 & 230 & 0 & 0 & 0 & co \\
\hline $67 X-6,29-32$ & 867 & 124 & 124 & 0 & 124 & $\mathrm{r}$ \\
\hline $68 \mathrm{X}-1,30-35$ & 414 & 377 & 37 & 20 & 0 & 382 \\
\hline $70 X-1,58-62$ & 535 & 459 & 0 & 0 & 0 & a \\
\hline $71 X-1,43-47$ & 284 & 284 & 95 & 0 & 0 & 2167 \\
\hline $71 X-2,125-127$ & 94 & 471 & 94 & 0 & 0 & co \\
\hline $72 X-1,37-40$ & 393 & 42 & 30 & 0 & 0 & co \\
\hline $74 X-1,45-49$ & 361 & 68 & 60 & 0 & 22 & $\mathrm{r}$ \\
\hline $74 X-2,20-24$ & 562 & 491 & 35 & 0 & 0 & $\mathrm{r}$ \\
\hline $74 X-4,1-4$ & 1126 & 670 & 260 & 0 & 0 & 110 \\
\hline $75 X-1,53-56$ & 417 & 224 & 160 & 0 & 0 & 128 \\
\hline $75 X-2,17-21$ & 224 & 140 & 0 & 0 & 0 & co \\
\hline $75 X-3,16-21$ & 123 & 61 & 0 & 0 & 0 & a \\
\hline $75 X-4,66-70$ & 1319 & 466 & 39 & 0 & 0 & co \\
\hline $76 X-3,4-6$ & 1413 & 1400 & 20 & 0 & 0 & co \\
\hline $77 X-4,68-73$ & 289 & 144 & 48 & 0 & 72 & 336 \\
\hline $78 \mathrm{X}, \mathrm{cc}, 12-16$ & 495 & 330 & 124 & 0 & 0 & 410 \\
\hline $79 X-1,14-18$ & 5200 & 743 & 248 & 0 & 0 & 495 \\
\hline $79 X-2,19-25$ & 508 & 313 & 0 & 0 & 39 & 300 \\
\hline $80 X-2,15-18$ & 418 & 751 & 10 & 0 & 167 & 2600 \\
\hline
\end{tabular}

Abbreviations are as follows: DINO = dinocysts; $\mathrm{P}-\mathrm{S}=$ pollen, fern and moss spores; ACRI = acritarchs; $\mathrm{BS}=$ black spores (sensu Mudie, 1987); DR = reworked palynomorphs; FORAM = foraminifer linings; $\mathrm{a}=$ abundant $(>1000 / \mathrm{g}) ; \mathrm{co}=$ common $(<1000>100 / \mathrm{g}) ; \mathrm{r}=\operatorname{rare}(<100 / \mathrm{g})$.

first and last occurrences of taxa that define our assemblage zones in Hole 646B will prove to have correlative significance, as we suggest below.

\section{Dinocyst Assemblage Zone HNMI}

Samples 105-646B-80X, CC to $-80 \mathrm{X}-2,2-4 \mathrm{~cm}$, approximately 767 to $760 \mathrm{mbsf}$, are lower upper Miocene (mid-Tortonian).

The top of this assemblage zone is defined by the last occurrence of Nematosphaeropsis major. The base is undefined. Other notable occurrences within this assemblage zone are Achomosphaera andalousiensis?, Gen. et sp. indet., Incertae sedis sp. 1 of Edwards, 1984b, Cymatiosphaera? invaginata, and Operculodinium janduchenei.

Achomosphaera andalousiensis is questionably recorded from this assemblage zone and has not previously been recorded from sediments older than middle Miocene (see "Systematics" section, this chapter). Gen. et sp. indet. is a conspicuous form present throughout this assemblage zone (to Sample 105-646B$80 \mathrm{X}, \mathrm{CC}$ ) and is probably conspecific with Evittosphaerula? sp. 2 of Manum et al. (in press) and Evittosphaerula sp. 1 of Mudie (in press), which are present in putative middle to early late Miocene sediments at ODP Sites $642 \mathrm{C}$ and $643 \mathrm{~A}$ in the Norwegian Sea (Mudie, in press).

The presence of Incertae sedis sp. 1 of Edwards, 1984b may indicate a late Miocene or younger age for assemblage Zone HNM1. Although not frequently recorded in the literature, a stratigraphic range of top middle or lower upper Miocene through lower Pliocene is suggested for this distinctive species.

Cymatiosphaera? invaginata occurs rarely in both samples from Zone HNM1, but occurs fairly persistently and sometimes commonly in successive assemblage zones of this study. Neither the stratigraphic nor geographic distribution of this acritarch species is reliably known, although it may range from middle Miocene through lowermost Pleistocene in the North Atlantic region. However, it is a common constituent of some samples from the upper Miocene and lower Pliocene of DSDP Site 611 in the northern North Atlantic and the Norwegian Sea.

Operculodinium janduchenei occurs persistently throughout Zone HNM1 and successive assemblage zones. This species has been recorded from the lower Miocene of the British Southwestern Approaches (Powell, 1988) but lowest records of fairly persistent occurrence are from the lower upper Miocene (e.g., the Rockall Plateau, Edwards, 1984b, using the correlation of Baldauf, 1984 and Backman, 1984).

The absence of Palaeocystodinium from assemblage Zone HNM1 and succeeding assemblage zones suggests an age no older than late middle Miocene. The highest reliable recorded occurrence for Palaeocystodinium is within the lowermost part of nannofossil Zone NN11 (lower upper Miocene), from both the Goban Spur (Brown and Downie, 1985) and the Rockal Plateau (Edwards, 1984b; Backman, 1984, p. 421). Manum et al. (in press) also place the last occurrence of Palaeocystodinium in the putative lower upper Miocene (lower part of their $A$. andalusiensis Zone) of the Norwegian Sea. However, elsewhere within the North Atlantic region and Europe, the last occurrence of this genus has been recorded from the upper middle Miocene (Harland, 1979; Duffield and Stein, 1986a; Powell, 1986b). Thus, the last appearance of Palaeocystodinium is apparently diachronous (see also Head et al., c, this volume, for further discussion), and this is supported by its notable absence from the entire upper Miocene of DSDP Site 611, which was drilled in drift deposits on the flank of the Gardar Ridge in the central North Atlantic, southeast of Greenland (Mudie, 1987). Palaeocystodinium was recorded from the middle and possible upper Miocene of ODP Site 645, Baffin Bay (Head et al., c, this volume), although its last appearance is not precisely constrained. We consider the absence of Palaeocystodinium in our samples from Site 646 to suggest an age no less than late middle Miocene, possibly post-dating the earlier part of the Tortonian (early late Miocene).

A late Miocene age assignment for assemblage Zone HNM1 is further supported by the absence of the Systematophora placacantha/S. ancyrea complex. The last occurrence of this species complex is also apparently diachronous and ranges from middle Miocene (Harland, 1978; Manum, 1976; Williams, 1978; Piasecki, 1980; Edwards, 1984b; Bujak and Matsuoka, 1986a) to upper Miocene (Partridge, 1978; Powell, 1986c, extending partly up into planktonic foraminifer Zone N17; Manum et al., in press). At Site 645 in Baffin Bay, $S$. ancyrea has a last occurrence in the middle or lower upper Miocene (Head et al., c, this volume). Systematophora spp. (as with Palaeocystodinium) are notably absent from the entire upper Miocene of DSDP Site 611 from the central North Atlantic (Mudie, 1987), although the cause of last-occurrence diachroneity is not well understood for these species at present.

Overall, the absence of Palaeocystodinium spp. and the Systematophora placacantha/S. ancyrea complex from assemblage 
Zone HNM1 and succeeding assemblage zones is consistent with the age of middle late Miocene, determined by the Leg 105 Scientific Party.

\section{Dinocyst Assemblage Zone HNM 2}

Samples $105-646 \mathrm{~B}-79 \mathrm{X}-1,108-110 \mathrm{~cm}$, to $72 \mathrm{X}-1,37-40 \mathrm{~cm}$, approximately 760 to $682 \mathrm{mbsf}$, are upper Miocene (middle to upper Tortonian).

The base of this assemblage zone is defined by the disappearance of $N$. major, and the top is defined by the last occurrence of Gen. et sp. indet. Other notable last occurrences within this assemblage zone are Labyrinthodinium truncatum and Impagidinium sp., cf. I. aculeatum, while cf. Operculodinium sp. of Piasecki (1980) has its last common occurrence in this assemblage zone (although it occurs rarely to Sample 105-646B-62X$02,19-23 \mathrm{~cm}$ ).

As mentioned above, Gen. et sp. indet. is probably conspecific with Evittosphaerula sp. 1 of Mudie (in press). This species has a last occurrence in ODP Hole 642C, Norwegian Sea, at a magnetochronological age of about $8 \mathrm{Ma}$, which is remarkably near the last occurrence of Gen. et sp. indet. and which was placed at the top of Chronozone 9 (Chronozone C4A) at $7.9 \mathrm{Ma}$ at Site 646 (Srivastava, Arthur, et al., 1987, Site 646 chapter, p. 466). L. truncatum has not often been identified with certainty from sediments younger than middle Miocene, but this species occurs in the putative lower upper Miocene of the Norwegian Sea (Manum et al., in press). Operculodinium sp. of Piasecki also has its last occurrence in the early late Miocene of the Norwegian Sea (Mudie, 1988). Several new species, Capillicysta gloriana, Cristadinium diminutivum, Impagidinium sp. 1, and Corrudinium? labradori, appear for the first time in assemblage Zone HNM2, and Acritarch sp. 2 also is restricted to this assemblage zone. In summary, dinocyst ranges at Site 646 generally support a late Miocene age for this assemblage zone. Because a late Miocene age is well established from other data for Site 646 , apparently, L. truncatum, if not reworked, has an unusually high stratigraphic range at this high-latitude site, as well as in the Norwegian Sea.

Calcareous nannofossil evidence (Knüttel et al., this volume) indicates that the stratigraphic sequence below Sample 105-646B$75 \mathrm{X}-1,108-110 \mathrm{~cm}$, is equivalent to, or older than, nannofossil Zone NN10. Paleomagnetic results place dinocyst assemblage Zone HNM2 within the later part of the early late Miocene.

\section{Dinocyst Assemblage Zone HNM3}

Samples 105-646B-71X-2, 125-127 cm, to -67X-3, 50-53 cm, approximately 682 to 636 mbsf, are upper Miocene (upper Tortonian).

The base of this assemblage zone is defined by the disappearance of Gen. et sp. indet., and the top is defined by the last appearance of Gongylodinium serratum. Other notable species that have their last appearances within this assemblage zone are Nematosphaeropsis sp. 1 and Impagidinium sp. 1. Species restricted to, or occurring for the first time, in this assemblage zone include Selenopemphix sp. 1 and sp. 2, Cerebrocysta? namocensis, Nematosphaeropsis sp. A of Wrenn and Kokinos (1986), and Selenopemphix? indentata. The stratigraphic significance of these species is not yet known.

\section{Dinocyst Assemblage Zone HNM4}

Samples 105-646B-66X-2, 20-23 cm, to $-60 \mathrm{X}, \mathrm{CC}$, approximately 636 to $564 \mathrm{mbsf}$, are upper Miocene (uppermost Tortonian).

The base of this assemblage zone is defined by the disappearance of Gongylodinium serratum, and the top is defined by the base of assemblage Zone HNM5, which is marked by the first appearance of Muraticysta microornata. Invertocysta spp. have their last regular occurrence near the base of HNM4. Paralecaniella indentata, which is not known to range above the late Miocene, has its last occurrence within assemblage Zone HNM4, although reworking may account for at least some specimens recorded here. Single specimens of Pentadinium laticinctum laticinctum were recorded from this assemblage zone and from the overlying assemblage Zone HNM5 (Sample 105-646B-56X-02, $17-20 \mathrm{~cm})$. This species, too, is not known to range above the late Miocene (see "Systematics" section, this chapter), although it may be reworked in this study. Lejeunecysta sp. cf. L. tenella is restricted to this assemblage zone. Lejeunecysta tenella has not been recorded from above the middle Miocene (see "Systematics" section, this chapter).

\section{Dinocyst Assemblage Zone HNM5}

Samples 105-646B-59X, CC to -50X-1, 131-135 cm, approximately 564 to $470 \mathrm{mbsf}$, are late Miocene (Messinian) and earliest Pliocene.

The base of this assemblage zone is defined by the first appearance of Filisphaera? sp. cf. F. filifera. Several other species are first recorded within this assemblage zone, including Impagidinium fenestroseptatum, Tectatodinium pellitum, cf. Filisphaera sp. A, and Muraticysta microornata. These four species appear just above the Miocene/Pliocene boundary and, collectively, may prove a useful regional indicator of the lowermost Pliocene. The last occurrence of Spiniferites sp. cf. S. ellipsoideus occurs in this assemblage zone. This species is not known to range above the lower Pliocene (Bujak and Matsuoka, 1986a).

The presence of Filisphaera? sp. cf. F. filifera? Bujak, 1984 within this assemblage zone may have local stratigraphic significance. $F$. filifera is common in the lower Pliocene at Site 646 (de Vernal and Mudie, a, this volume) and has its first appearance in the upper lower Pliocene of DSDP Site 611 from the northern North Atlantic (Mudie, 1987). However, first appearances of $F$. filifera are apparently somewhat diachronous and range from the middle Miocene (Manum et al., in press) or uppermost Miocene (Mudie, in press) of the Norwegian Sea, upper Miocene for the Bering Sea (Bujak, 1984), lower Pliocene at latest for the Arctic Ocean (Mudie, 1985; Aksu and Mudie, 1985a), lower Pliocene for western and northern Pacific region (Bujak and Matsuoka, 1986a, 1986b), and upper Pliocene for the central North Atlantic (Mudie, 1987).

Evidence from both nannofossils and planktonic foraminifers from Site 646 indicates that the Miocene/Pliocene boundary can be placed just above Sample 105-646B-53X, CC (506.90 mbsf; Baldauf, Clement, et al., this volume). At Site $646, F$ ? sp. cf. $F$. filifera has a first occurrence at the base of dinocyst assemblage Zone HNM5, just above the top of Chronozone 6 (placed within Section 105-646B-61X-3) within the upper Messinian (Srivastava, Arthur, et al., 1987, Site 646 chapter, p. 466).

\section{Characterization of Dinocyst Assemblages and Comparison with Other Areas}

Marine palynomorph diversity varies from 6 to 28 (average $=17$ ) taxa per sample per slide examined. Most samples are characterized by fairly frequent to abundant Batiacasphaeral Cerebrocysta group A and Cymatiosphaera? invaginata. In addition, Impagidinium? pallidum, Impagidinium spp., Nematosphaeropsis lemniscata, Reticulatosphaera actinocoronata, Operculodinium janduchenei, and Habibacysta tectata have variable abundances but are present in most samples.

Spiniferites/Achomosphaera spp. and Operculodinium spp. are poorly represented compared with upper Miocene sediments elsewhere in the North Atlantic (Edwards, 1984b; Mudie, 1987; Mudie, in press) and the northern Pacific (Bujak and Matsuoka, 1986a). More than 13 species of protoperidiniacean cyst taxa are recorded in this study, with the highest diversity in assemblage 
Zones HNM3 and HNM4 (Table 1). These taxa represent a small proportion of the total dinocyst assemblages but are present in most samples. Gen. et sp. indet., Gongylodinium serratum, and Invertocysta spp. are well represented in the lower part of the upper Miocene section, while the uppermost Miocene to lowermost Pliocene is characterized by the presence of one or more of the following: Tectatodinium pellitum, Muraticysta microornata, Filisphaera? sp., cf. F. filifera, and cf. Filisphaera sp. A.

During the past $8 \mathrm{yr}$, an increasing number of investigations have been conducted for upper Miocene dinocysts, from the deep-water areas of the northern and western Pacific, North Atlantic, Norwegian Sea and Baffin Bay, and from the type sections in Europe. Spatial coverage and quantitative and systematic studies data are insufficient at present to reconstruct the paleobiogeography of dinocyst assemblages precisely, but regional similarities and differences among assemblages are beginning to emerge. Unfortunately, in two key areas with respect to this study, namely, the Beaufort Sea and Arctic Ocean, there exists only preliminary (Beaufort Sea: Bujak and Davies, 1981; Dixon et al., 1984) or no published data (Arctic Ocean) for late Miocene dinocysts.

The upper Miocene assemblages of this study have a number of elements in common with those from other deep-sea sites in the Northern Hemisphere, but particularly with assemblages from the central North Atlantic (DSDP Site 611) and from the eastern Norwegian Sea (ODP Sites 642 and 643). Similarities include high frequencies of Cymatiosphaera? invaginata from Site 646 (this chapter; de Vernal and Mudie, a, this volume), Site 611 (Mudie, 1987), Sites 642 and 643 (Mudie, in press) compared with lower vaues from the southern North Atlantic (DSDP Site 607 , Mudie, 1987) and possible absence elsewhere (although this is a small form that may have been overlooked by previous authors). Other key features in common include the frequent presence of $I$.? pallidum, which appears to have a restricted highlatitude distribution, and by the low representation of thermophilic taxa (Tuberculodinium and Polysphaeridium). The possible co-occurrence of Gen. et sp. indet. at Site 646 and at Site $642 \mathrm{C}$ in the Norwegian Sea (as Evittosphaerula? sp. 2 of Manum et al., in press) is also noteworthy when comparing assemblages between these two areas. In contrast, the upper Miocene assemblages of the northern North Atlantic and Norwegian Sea do not have the diverse protoperidiniacean representation observed at Site 646. Furthermore, Operculodinium janduchenei, which occurs regularly at Site 646 and at various localities within the North Atlantic and Europe (including high frequencies in the Gulf of Mexico) appears to be absent from the upper Miocene of the northern Pacific and Bering Sea and is frequent only in the upper Miocene of Hole $642 \mathrm{C}$ of the Norwegian Sea. The presence at Site 646 of Nematosphaeropsis sp. A of Wrenn and Kokinos, 1986, and Forma C of Wrenn and Kokinos, 1986, also suggests some affinities between the marine palynoflora of this site and that of lower latitudes.

\section{Sporomorph Assemblages}

Spores and pollen account for the major proportion of palynomorphs in the assemblages. The most abundant forms are bisaccate pollen (attributable mainly to Pinus and Picea), Tsuga ignicula pollen, small inaperturate coniferous pollen, triporate pollen (including Betula and Carpinus/Corylus types), sphagnaceous spores (mainly Stereisporites stereoides Pot. and Ven., 1934), and in some samples, Sciadopitys pollen (mainly Sciadopityspollenites serratus [Pot. and Ven.] Raatz, 1937). Small numbers of osmundaceous spores (Baculatisporites comaumensis [Cookson, 1953] Potonié, 1956 sensu lato, and Verrucosisporites opimus/septentrionalis Manum, 1962, types), lycopodeaceous spores (mainly Reticulatisporites austroclavatites [Cookson, 1953]), and a morphotype closely comparable to spores of the extant Selaginella selaginoides, occur in most samples. Herbaceous pollens, many of which evolved rapidly during the Neogene, were recorded sporadically as isolated specimens in this study, no doubt because of the oceanic location of Site 646. Pollen referable to Chenopodium were seldom recorded (Samples $105-646 \mathrm{~B}-76 \mathrm{X}, \mathrm{CC}$ and $-63 \mathrm{X}-3,37-39 \mathrm{~cm}$ ) as was a single lophate compositaceous pollen (Sample 105-646B-71X-2, 125-127 cm, Pl. 7, Figs. 10, 15).

Pollen types referable to the modern temperate and warmtemperate forest genera (Tilia, Pterocarya, Carya, Liquidambar, Nyssa, Engelhartia) and temperate forest conifers (including Metasequoia and Ginkgo [possibly reworked]) occur in low numbers in the Miocene samples (up to Core 105-646B-62X). A warm-temperate climate is inferred for the source vegetation for most of the late Miocene. The disappearance of these taxa in the latest Miocene and their absence or rarity in younger sediments (de Vernal and Mudie, a, this volume) strongly suggest a major climatic cooling that began at about $6.5 \mathrm{Ma}$. This apparent cooling occurs about $1.5 \mathrm{Ma}$ later than the late Miocene cooling recorded by oxygen-isotope data at Site 646 (Aksu and Hillaire-Marcel, this volume) and about $0.5 \mathrm{Ma}$ later than the late Miocene cooling recorded within Chronozone 7 at DSDP Site 611 .

\section{PALEOENVIRONMENTAL AND PALEOCEANOGRAPHIC INTERPRETATION}

In today's oceans, dinoflagellates that produce large numbers of organic walled cysts mainly occur in shelf and estuarine environments, and no exclusively oceanic species are known to exist that produce organic walled cysts. ${ }^{a}$ Despite this, cysts are found in Holocene to sub-Holocene bottom sediments throughout the North Atlantic (Harland, 1983; Mudie and Short, 1985; de Vernal, 1986), and their distribution may largely attest to the major influence of ocean current transport, in this case, of the Gulf Stream, North Atlantic Drift (NAD), and northern branches of this current. On the other hand, a few long-term studies have been conducted of dinoflagellates in high-latitude oceanic areas (e.g., at Station Bravo in the central Labrador Sea; Holmes, 1956) and one can clearly see that dinoflagellate blooms do occur offshore in late summer; these may be a potential source of cysts in oceanic areas.

Site 646 is situated about $250 \mathrm{~km}$ from the 400 -m shelf break; it is possible that most of the dinoflagellate species reported here (although not necessarily the Incertae sedis and Acritarch taxa) were transported a considerable distance from various environments on the shelf. This places some constraints upon the paleoenvironmental analysis of the assemblages but provides an opportunity to consider the influence exerted by changing paleocurrents. An additional limitation arises from the rather small number of oceanic Neogene dinocyst studies available for comparison. Nevertheless, some general comments relating to paleoenvironment and possible effects of paleoceanic currents upon

a The cyst-producing strategy probably evolved in many dinoflagellates as a means of surviving unstable ecological conditions that characterize nearshore (and glacial/periglacial) environments (Wall et al., 1977; see also detailed discussions in Sarjeant et al., 1987). Cyst morphology may reflect the advantage gained by rapid sinking, such as branched processes to promote flocculation etc., that would minimize the risk of being swept into deeper water. Laboratory incubating experiments on a large number of species of live dinoflagellates indicate that for even fast excysting species, the cyst must undergo a minimum dormancy period (Dale, 1983). Cysts are nonmotile and if swept into deep waters, will sink beyond the depth at which the excysted motile stage can be reasonably expected to swim back to the photic zone. On these grounds, it appears that the cyst strategy for most deep ocean dinoflagellates is not merely superfluous but, indeed, a liability, unless such cysts had special adaptations, such as low sinking velocities, density regulation capabilities, or short encystment duration, as suggested by Dale (1983). 
the taphonomy of dinocyst assemblages are discussed as follows:

1. Asemblages often contain a mixed association of variable proportions of inner and outer neritic to "oceanic" species (following the ecological classification of Wall et al., 1977; Harland, 1983; and Wrenn and Kokinos, 1986). Outer neritic to oceanic components include Impagidinium spp., Nematosphaeropsis spp., Incertae sedis 1 of Edwards, $1986 \mathrm{~b}$, and Invertocysta spp. From its presently known distribution (see "Systematics" section, this chapter), Cymatiosphaera? invaginata is probably an oceanic form as well. $O$. janduchenei, which occurs consistently but in small numbers, may be an outer neritic species. Estuarine and inner to outer neritic species include Selenopemphix spp., certain other protoperidiniacean species, and possibly $T$. vancampoae (see discussion in "Systematics" section, this chapter).

2. The absence of Polysphaeridium zoharii and the scarcity of Tuberculodinium vancampoae, which are both warm-water indicators, and the regular occurrence of I.? pallidum (an apparently arctic/subarctic species) point to temperate to cool surface waters and persistent influence of subarctic surface waters, formed by mixing of arctic (East Greenland Current) and warm temperate (North Atlantic Drift [NAD]) surface waters, perhaps analogous to the origin of today's West Greenland Current (Aksu and Mudie, 1985b). Planktonic foraminifers and calcareous nannofossils from this interval also indicate cool or temperate surface waters for the upper Miocene at this site, with only minor subtropical incursions (Knüttel et al., this volume; Aksu and Kaminski, this volume). Other similarities between upper Miocene assemblages of this site (e.g., the regular occurrences of Cymatiosphaera? invaginata and Batiacasphaera/Cerebrocysta group A) with ODP/DSDP sites of the central North Atlantic (Mudie, 1987) and Norwegian Sea (Mudie, in press) further support the existence of a southward-flowing, proto-East Greenland Current at this time. Drift deposits on the Feni and Gardar ridges also attest to the existence of NSOW over the lceland-Faroes Ridge throughout most of the late Miocene (Kidd and Hill, 1986). A strong mixing of Arctic and Atlantic watermasses probably occurred at Site 646. The high species diversity (compared with the arctic to subarctic sites, including Baffin Bay and the Beaufort and Norwegian seas) and presence of Operculodinium janduchenei (which occurs regularly at this site and at various localities in the North Atlantic and Europe, including high frequencies in the Gulf of Mexico, but is apparently absent from the late Miocene of the northern Pacific and Bering Sea) point to a persistent influence of North Atlantic waters at this site.

3. The rather diverse representation of protoperidiniacean cysts, particularly in dinocyst assemblage Zones HNM3 and HNM4, is notable because these cyst forms are not characteristic of upper Miocene asemblages elsewhere in the central to northern North Atlantic or Norwegian Sea and they may either reflect oceanographic conditions that are fairly specific to Site 646 or to the influence of water derived from northern Pacific regions via the Arctic Channels. Elsewhere, abundant protoperidiniacean cysts have been attributed variously to (1) high influxes of nutrients owing to oceanic upwelling (e.g., Bujak, 1984; Duffield and Stein, 1986b), (2) high river discharge (Duffield and Stein, 1986a), or (3) a decrease in sea level (A. J. Powell, reported by J. B. Riding, in The British Micropalaeontologist, 1986, 28:14), while a cold current influence was suggested by Matsuoka (1985a) for abundant upper Miocene presence around parts of northern Japan. Protoperidiniacean abundance also has been linked to heterotrophy and related to possible ice cover during the Quaternary (Dale, 1985; see also Harland, 1988a) The relationship between high oceanic productivity and proto- peridiniacean cyst abundance for various areas of the world has been discussed by Matsuoka (1987, p. 75-79).

4. Of particular note is the approximately synchronous last occurrence of Gen. et sp. indet., presence of the R3/R4 seismic reflector (possibly representing a hiatus of about $0.5 \mathrm{Ma}$ ), and a benthic foraminifer change, all of which occur at around $680 \mathrm{mbsf}$ (top of Chronozone 9 [-C4A] at about 7.9 Ma), in the middle Tortonian (Fig. 2). Many scientists believe that an important change in deep-water characteristics and an intensification of deep circulation occurred at this time, which may have been a precurser to large-scale drift deposition at Site $646(\mathrm{Ka}-$ minski, Gradstein, Scott, et al., this volume; Gradstein and Srivastava, 1980). Below 680 mbsf, benthic foraminifer assemblages have affinities with Antarctic Bottom Water (ABW) faunas typical of the eastern North Atlantic at this time (Kaminski, Gradstein, Scott, et al., this volume). Above $680 \mathrm{mbsf}$, benthic foraminifer assemblages at Site 646 have affinities with the Norwegian-Greenland Sea and indicate a replacement of southern-sourced bottom water by Denmark Straits Overflow Water (DSOW). The last occurrence of the dinocyst Gen. et sp. indet. at this time is apparently remarkably similar to its disappearance at ODP Site $642 \mathrm{C}$ in the Norwegian Sea (about $8 \mathrm{Ma}$ ) during an interval of continuous deposition, and it implies a widespread oceanic event that simultaneously affected both areas. In addition, this species may have been reported from the upper Miocene of the Mediterranean (as Thalassiphora? sp. A in Powell, 1986c; see "Systematics" section, this chapter), although the oceanographic implications of this possible geographic distribution are uncertain. Kidd and Hill (1986) reported an event of late Miocene age from the drift deposits on the Feni and Gardar ridges at DSDP Sites 610 and 611, which they attributed to possible Mediterranean isolation, although this event may post-date the middle Tortonian event reported at Site 646.

5. Through the entire upper Miocene and lowermost Pliocene of Site 646, dinocyst assemblages (with the exception of Gen. et sp. indet.) appear to have mixed affinities with the Arctic and northern North Atlantic, with a minor influence from the southwest North Atlantic. A direct contribution of the Gulf Stream at this site is unlikely since the establishment of the cold Labrador Current had pushed it to the south Labrador Sea by the late Miocene (Gradstein and Srivastava, 1980). The apparently mixed assemblages can be explained by the mixing of Arctic waters from the Labrador and East Greenland Current with northward-flowing branches of the NAD, resulting in the formation of the warm Irminger Current flowing westward along the southern margin of Greenland and northward over the southwest Greenland margin (Aksu and Mudie, 1985b) in a pattern somewhat analogous to that occurring today (Fig. 3). An alternative (or complementary) possibility is that the mixing of dinocyst assemblages occurred during bottom-water transport, rather than by surface waters. Best evidence for a persistent influence of deep NSOW (at least down to $680 \mathrm{mbsf}$ ) at this site comes from its seismic continuity with the Eirik Ridge (Srivastava, Arthur, et al., 1987, Site 646 chapter), a drift deposit constructed by southwesterly to westerly prograding bottom-current deposition.

6. The Miocene/Pliocene boundary at Site 646 has been located at about 500 mbsf and occurs near the R2 seismic reflector. Higher and more consistent carbonate contents in sediments near the boundary are considered to reflect a minor warming in the early Pliocene (equivalent to $1 \% 0 \delta^{18} 0$; Aksu and HillaireMarcel, this volume; see also Keigwin et al., 1987) and perhaps an increased contribution of less-corrosive, northern-sourced deep water (Hooper and Weaver, 1987; Kaminski, Gradstein, et al., this volume). Several dinocyst species (I. fenestratoseptatum, T. pellitum, cf. Filisphaera sp. A, and M. microornata) 


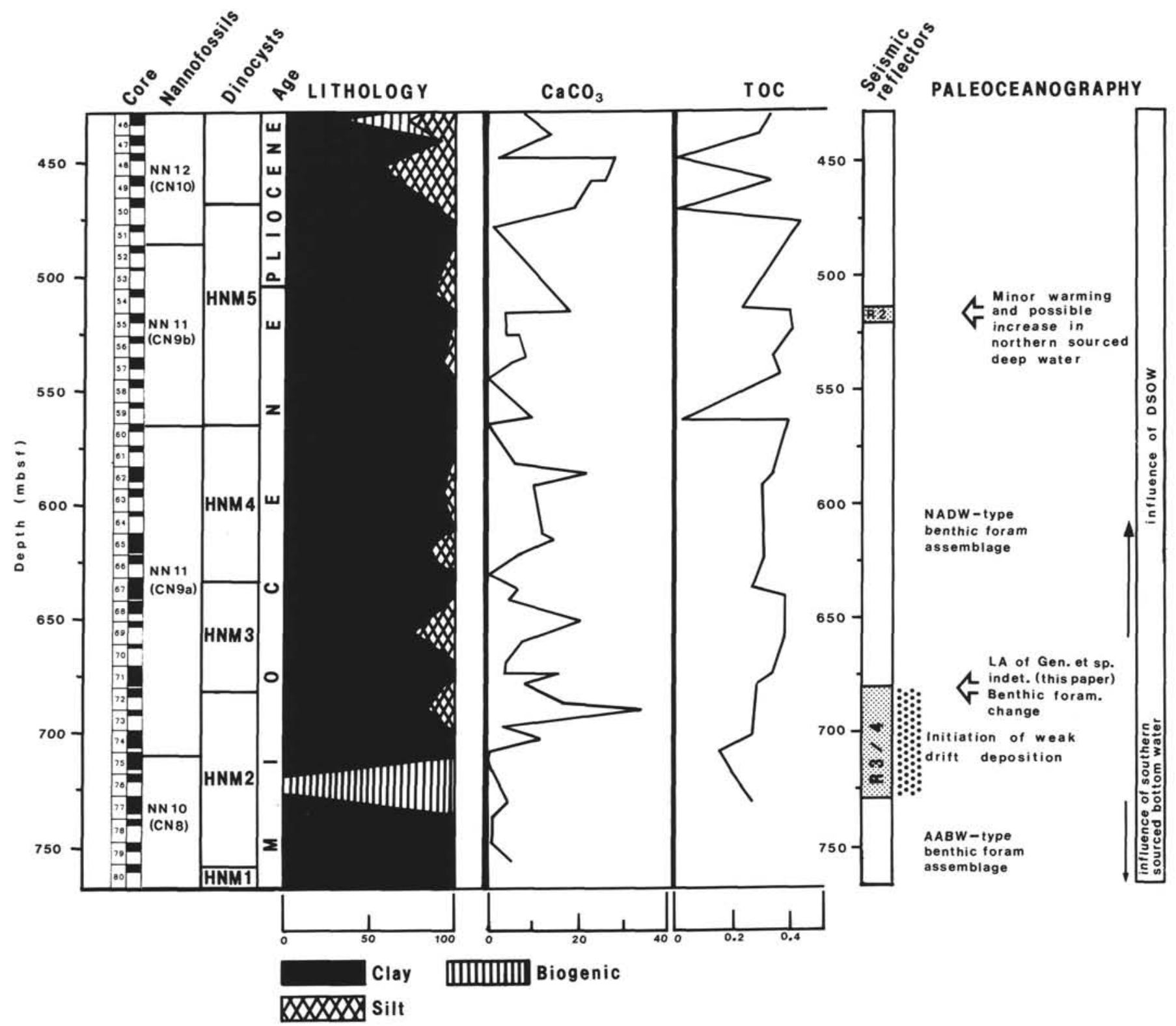

Figure 3. The upper Miocene and lowermost Pliocene of Hole 646B showing correlation of dinocyst assemblage zones (HNM1 through HNM5, this study), with core number and recovery (Srivastava, Arthur, et al., 1986, Fig. 27), calcareous nannofossil zones (Knüttel et al., this volume), age (Baldauf, Clement, et al., this volume), lithology, carbonate content, and total organic carbon (all from Srivastava, Arthur, et al., 1986, Fig. 57), seismic reflectors (Srivastava, Arthur, et al., 1986), and paleoceanographic events (Kaminski, Gradstein, et al., this volume). TOC $=$ total organic carbon, NADW $=$ North Atlantic Deep Water, AABW = Antarctic Bottom Water, DSOW $=$ Denmark Strait Overflow Water.

have their first occurrence in the earliest Pliocene at this site, although it is not presently possible to determine if the slight warming was a controlling factor.

\section{Miocene Dinocyst Evolution}

Changes in dinoflagellate diversity and speciation rates though Phanerozoic time have been discussed by several authors (Tappan and Loeblich, 1971, 1972, 1973; Bujak and Williams, 1979). However, before 1986, relatively few studies of Miocene dinocysts had been published, and few reports have included detailed taxonomy. Not surprisingly, recent studies (including those in this volume) indicate a higher diversity of dinoflagellates for the Miocene than was previously reported. While it is perhaps still premature to interpret dinocyst diversity and speciation curves for the Miocene, one may expect them to correlate broadly with major changes in global sea level and oceanographic circu- lation patterns, temperature, and salinity that occurred during the later part of this epoch. It may be of particular interest to assess whether late Miocene changes in deep-water circulation and eustatic sea-level lowering during the late Miocene provided a nutrient-driven stimulus for the evolution of the Protoperidiniaceae (which includes heterotrophic species in modern floras), and whether this was further stimulated by the onset of colder climatic conditions that gradually led to their dominance in Pleistocene sediments (Mudie, in press; de Vernal and Mudie, a, b, this volume).

\section{CONCLUSIONS}

1. Spores and pollen account for the major proportion of palynomorphs in assemblages, although reworking from Paleogene and Upper Cretaceous sediments may be responsible for a large number of these. A warm-temperate climate is inferred for 
the source vegetation for most of the late Miocene, with a climatic cooling suggested for the latest Miocene, at about $6.5 \mathrm{Ma}$, and which apparently post-dates an isotopic cooling signal at Site 646 by about $1.5 \mathrm{Ma}$.

2. Dinoflagellate assemblages at Site 646 contain both oceanic and neritic species, with the latter perhaps being transported to the site by bottom-water currents. Assemblages point to temperate to cool surface waters, with perhaps minor subtropical incursions.

3. Upper Miocene marine palynomorph assemblages at Site 646 show some similarities with other oceanic Northern Hemisphere sites and, in particular, with the central North Atlantic (DSDP Site 611) and the eastern Norwegian Sea (ODP Sites 642 and 643). This similarity gives support to the existence of a southward-flowing, proto-East Greenland Current during the late Miocene. However, some important differences at Site 646, in particular its diverse protoperidiniacean representation, may reflect a strong mixing of Arctic and Atlantic watermasses at this site.

4. The last occurrence of the dinoflagellate Gen. et sp. indet. at the top of assemblage Zone HNM2 coincides with (1) the presence of the R3/R4 seismic reflector doublet, (2) a change in sedimentation rate, and (3) a change in benthic foraminifer assemblages, all of which occur at around 680 mbsf (about 7.9 $\mathrm{Ma}$ ). This event is approximately contemperaneous with the highest occurrence of Evittosphaerula sp. 1 of Mudie (in press, a form probably conspecific with Gen. et sp. indet. of Site 646) in the Norwegian Sea, which has a magnetochronological age of about $8 \mathrm{Ma}$. We interpret this to indicate a widespread oceanic event.

5. The first appearance of $F$ ? sp. cf. F. filifera at the base of assemblage Zone HNM5 (late Miocene, Messinian) and the appearance of $I$. fenestroseptatum, $T$. pellitum, cf. Filisphaera sp. A, and M. microornata near the Miocene/Pliocene boundary, within Zone HNM5, may prove collectively useful for regional correlation and may indicate a change in oceanic conditions just before the end of the Miocene.

\section{SYSTEMATIC DESCRIPTIONS OF MARINE PALYNOMORPHS}

(with notes on paleoecology and stratigraphic distribution) $^{\mathrm{b}}$

Division PYRRHOPHYTA Pascher, 1914

Class DINOPHYCEAE Fritsch, 1929

Order PERIDINIALES Haeckel, 1894

Genus ACHOMOSPHAERA Evitt, 1963

Achomosphaera andalousiensis Jan du Chêne, 1977 emend. Jan du Chêne and Londeix, 1988

$$
\text { (Pl. 5, Figs. 9,12) }
$$

Remarks. A single specimen was positively identified. This species has been recorded from the Neogene of a number of locations within the North Atlantic, Norwegian Sea, and Europe (Jan du Chêne, 1977; Harland, 1978, 1979 [as "Spiniferites septentrionalis," see Mudie, 1987, p. 802; Brown and Downie, 1985, p. 646; and Jan du Chêne and Londeix, 1988]; Piasecki, 1980 [see Powell, 1986b, p. 123.]; Benedek, 1980; Brown and Downie, 1985; Mudie, 1987; Powell, 1986b, 1986c; Wrenn and Kokinos, 1986; Corradini and Biffi, 1988; Powell, 1988; Jan du Chêne and Londeix, 1988; Mudie, in press; and Manum et al., in press), from the Nile Delta, Egypt (El Beialy, 1988b), and questionably from the Bering Sea (as Spiniferites sp. A in Bujak and Matsuoka, 1986a). Additional Pleistocene records include Wrenn and Kokinos, 1986; Mudie, in press; de Vernal and Mudie, a, this volume. This species has a recorded stratigraphic range (see also Jan du Chêne and Londeix, 1988) of upper middle Miocene, (planktonic foraminifer Zone N12; Powell, 1986b) to upper Pleistocene and Holocene (as "S. septentrionalis" in Harland, 1977, and in Balch et al., 1983; as "Achomosphaera perforata" in Morzadec-Kerfourn, 1979, Pl. 31, Figs. 1,2,4, Pl. 35, Figs. 7-9, and 1984,

b This section does not include detailed descriptions or discussion of formally proposed new taxa that are documented in Head et al., b, this volume.
Pl. 2, Figs. 13-14; Harland, 1983, 1988a, 1988b; Turon and Londeix, 1988), but it shows a clear abundance acme in the upper Miocene to lower Pliocene intervals throughout most of the North Atlantic (Mudie, in press). Its rarity in this study may reflect the oceanic nature of the Site 646 dinocyst assemblages or indicate provincialism within the North Atlantic and adjacent areas for this species during the late Miocene. A. andalousiensis occurs sporadically in Pliocene-Pleistocene sediments at Site 646, with a last occurrence in the upper Pleistocene (de Vernal and Mudie, a, this volume). From its distribution in Quaternary North Sea sediments of the Witch Ground Formation Harland (1988a, p. 119) suggested that this species preferred cold, north-temperate to arctic climates. However, this interpretation is at variance with the abundant presence of $A$. andalousiensis in upper Pliocene and lower Pleistocene sediments of the subtropical Gulf of Mexico, as recorded by Wrenn and Kokinos (1986). It has been considered a characteristic species of the outer neritic environment of the temperate zone (Harland, 1983; Wrenn and Kokinos,1986).

\section{Genus BRIGANTEDINIUM Reid, 1974 cf. Brigantedinium spp.}

Remarks. This group includes small, spherical (less than $45 \mu \mathrm{m}$ diameter), brown, pigmented cysts having a somewhat crumpled appearance. An archeopyle was often indiscernible.

Genus BATIACASPHAERA Drugg, 1970/CEREBROCYSTA Bujak in Bujak et al., 1980

\section{Batiacasphaera/Cerebrocysta group A}

(Pl. 1, Figs. 1-6, 9-12, 17, 18, 23, 24)

Dimensions. Range in diameter, about 22 to $38 \mu \mathrm{m}$.

Description. Small, spherical, autophragmal cysts with low-angularity, trapezoidal? archeopyle having no discernible accessory sutures. Operculum free. Ornament is normally low and fine and usually forms a densely spaced, discontinuous reticulum. It consists of both short, sinuous rugulae and granulae showing varying degrees of fusion. There is considerable variation in prominence of ornament and degree of discontinuity of the reticulation, with some specimens being predominantly granulate, although at least some degree of fusion between granulae is usually present.

A detailed population study using the SEM will be required to subdivide this group on the basis of ornament and archeopyle style. Some of the more common forms are illustrated in Plate 1, Figures 1-3, 6, 9, 10, and 24 .

Discussion. Some specimens from this study fall within the definition of B. micropapillata, as defined by Stover (1977), which encompasses thin-walled forms having a variety of fine ornament (e.g., Pl. 1, Figs. 17, 18, 23). Some thicker-walled forms (about $1 \mu \mathrm{m}$ thick) may belong to $B$. sphaerica, but were included in this group as they intergrade with thinner-walled forms. However, in most cases the archeopyle style could not be positively determined because of folding of the cysts and, in some specimens, it appears to be precingular (e.g., Pl. 1, Figs. 1-3, 9, $10)$.

Batiacasphaera/Cerebrocysta group A is a common component of assemblages from the upper Miocene and lower Pliocene of Site 646 and includes specimens that also persist through the lower and middle Miocene of Baffin Bay (assigned to the Batiacasphaera micropapillata complex, in Head et al., c, this volume) and that range down to the middle Eocene at Site 647A, Labrador Sea (Head and Norris, this volume). Neogene specimens that are perhaps partly conspecific with Batiacasphaera/ Cerebrocysta group A include ?Pyxidiella sp. 1 of Mudie (in press), recorded from the lower Miocene to lower Pliocene of ODP Leg 104 of the Norwegian Sea (Mudie, in press) and forms provisionally assigned to Corrudinium sp. I and ?C. sp. II in de Vernal and Mudie, (a, this volume), which are common to abundant in Pliocene to lower Pleistocene sediments at Sites 646 and 647. B. micropapillata was recorded from the Oligocene to lower Miocene of Site 643, Norwegian Sea (Manum et al., in press) and from the middle Oligocene to lower Miocene from offshore the eastern United States (Stover, 1977). The earliest record of $B$. micropapillata to date is from the middle Eocene (nannofossil Zones CP13/CP14) of Central Java, Indonesia (Matsuoka, 1984).

Genus CAPILLICYSTA Matsuoka and Bujak in Matsuoka et al., 1987

Capillicysta gloriana Head et al. (b, this volume) 
Genus CEREBROCYSTA Bujak, in Bujak et al., 1980 emend. Stover and Williams, 1987.

Cerebrocysta? namocensis Head et al. (b, this volume)

Genus CORRUDINIUM Stover and Evitt, 1978

Corrudinium? labradori Head et al. (b, this volume)

Genus CRISTADINIUM Head et al. (b, this volume)

Cristadinium cristatoserratum Head et al. (b, this volume)

Remarks. This species occurs rarely from dinocyst assemblage Zones HNM1 through HNM4 (upper Miocene) of Site 646. It has also been recorded from the middle or lower upper Miocene of Baffin Bay (Head et al., c, this volume).

Cristadinium diminutivum Head et al. (b, this volume)

Genus DAPSILIDINIUM Bujak et al., 1980.

Dapsilidinium pastielsii (Davey and Williams, 1966) Bujak et al., 1980

Remarks. A single, well-preserved specimen was found in assemblage Zone HNM1. This species ranges down to at least the lower Eocene in the North Atlantic (Brown and Downie, 1984) and has a highest recorded occurrence in the lower Pliocene of the Norwegian Sea (Mudie, 1988). Elsewhere, D. pastielsii has a highest occurrence in the lower middle Miocene of the western and northern Pacific (Bujak and Matsuoka, 1986a); middle Miocene of northwestern Italy (Powell, 1986b); lower upper Miocene of the Grand Banks and Scotian Shelf, offshore Eastern Canada (Williams and Bujak, 1977b); upper Miocene of the Nile Delta, Egypt (El Beialy, 1988a); and has been recorded from the lower and middle Miocene of the British Southwestern Approaches (Powell, 1988, correlated to foraminifer Zones N5-N7 and N11, from Evans and Hughes, 1984), and Miocene of the Beaufort Sea (Dixon et al., 1984).

\section{Dapsilidinium pseudocolligerum (Stover, 1977) Bujak et al., 1980}

Remarks. Two well-preserved specimens were found. This species is known from the lower Oligocene (Stover, 1977) to middle Miocene (Edwards, 1984b; Manum et al., in press; Head et al., c, this volume) or lower upper? Miocene (Edwards, 1984b, correlated to nannofossil Zone NN8 from Baldauf, 1984; Head et al., c, this volume).

Genus DEFLANDREA Eisenack, 1938 emend. Williams and Downie, 1966

Deflandrea? sp. 1

(Pl. 3, Fig. 11)

Remarks. These cysts are cavate with a peridinoid outline, about $60 \mu \mathrm{m}$ in total length. The periphragm is thin and smooth, and the endophragm is thicker and smooth to faintly granulate. These cyst are dark (pigmented?), and preservation may be below average for the assemblage. Archeopyle shape could not be determined. These cysts may be reworked from Paleogene or Upper Cretaceous sediments.

Genus EMSLANDIA Gerlach, 1961

emend. Benedek and Sarjeant, 1986

Emslandia sp. 1

(Pl. 2, Figs. 17,18)

Remarks. A single specimen was recorded from assemblage Zone HNM4; it has a thick, spongy periphragm.

\section{Genus FILISPHAERA Bujak, 1984}

Filisphaera? sp. cf. F. filifera Bujak, 1984

(P1. 7, Fig. 2; also Pl. 5, Figs. 7 and 9 of Head et al., b, this volume)

Description. Cysts spherical to ovoidal and with two closely adpressed wall layers. Endophragm thinner than periphragm. Periphragm is from 1.5 to $2.5 \mu \mathrm{m}$ thick and appears radially striate in transverse optical cross-section and microreticulate in surface view, with lacunae that are generally less than $1 \mu \mathrm{m}$ wide. Archeopyle precingular, Type P, and large. Operculum free. A low apical lobe was occasionally seen. There are no other indications of paratabulation.
Dimensions. Range of maximum diameter (mean in brackets), $48(59) 65 \mu \mathrm{m}$. Ten specimens were measured.

Remarks. F. filifera as described by Bujak $(1984$, p. 185) has "a thin inner wall and thicker outer wall composed of radiating fibers. Surface of outer wall granulate." Specimens reported here as F.? sp. cf. F. filifera have a microreticulate wall structure in surface view; we have not determined whether the radially striate periphragm is from discrete fibers, as in $F$. filifera, or represents an extremely fine reticulum. SEM studies of both our specimens and of topotype specimens of $F$. filifera will be necessary to determine conspecificity.

Discussion. F. filifera previously has been recorded from the western and northern Pacific and Bering Sea (Matsuoka, 1983; Bujak, 1984; Bujak and Matsuoka, 1986a, 1986b), Arctic Ocean, (Mudie, 1985; Aksu and Mudie, 1985), northern and central North Atlantic (Mudie, 1987), and Norwegian Sea (Manum et al., in press; Mudie, in press). This species has a recorded stratigraphic range of middle Miocene (Manum et al., in press) to lower Pleistocene (Mudie, 1987; Bujak and Matsuoka, 1986a), and apparently has a diachronous first appearance, ranging from midMiocene of the Norwegian Sea (Manum et al., in press), late Miocene of the Bering Sea (Bujak, 1984), early Pliocene of the western and northern Paciflc (Bujak and Matsuoka, 1986a, 1986b; and as Tectatodinium pelitum in Matsuoka, 1983), and Arctic Ocean (Mudie, 1985) and late early Pliocene of Site 611 and late Pliocene of Site 607 from the central North Atlantic (Mudie, 1987). Mudie (1987, Table 3) considered this species "moderately cold tolerant," although the first appearance of $F$. ? sp. cf. F. filifera at Site 646 coincides approximately with the beginning of a slight warming phase in the latest Miocene (see Aksu and HillaireMarcel, this volume).

\section{cf. Filisphaera sp. A}

(Pl. 7, Figs. 1, 7, and 11)

Dimensions. Range of maximum diameter, 55(62)67 $\mu \mathrm{m}$. Six specimens were measured.

Description. Spherical to ovoidal cysts, with a low apical lobe present on some specimens. Wall consisting of two closely adpressed layers, a solid endophragm, and a thicker periphragm (1-2 $\mu \mathrm{m}$ thick) having a radially fibrous/granulate appearance in transverse optical cross-section. Periphragm upper surface appears coarsely granulated (surface view, bright field, X100 oil immersion), although it may appear microreticulate at slightly lower focus. Archeopyle precingular, Type P, and large, formed by the apparent loss of paraplate $3{ }^{\prime \prime}$. Operculum free.

Discussion. These cysts are similar to $F$.? sp. cf. F. filifera. However, the periphragm may be thinner and have a less well-ordered radial structure.

Genus GONGYLODINIUM Fenton et al., 1980

Gongylodinium serratum Head et al. (b, this volume)

Gongylodinium sp. cf. G. serratum Head et al. (b, this volume)

Genus HABIBACYSTA Head et al. (b, this volume)

Habibacysta tectata Head et al. (b, this volume)

Remarks. This species has been recorded from the middle Miocene to lower upper Pleistocene of the Norwegian Sea (as Dinocyst sp. 1 in Mudie, in press), from the middle or upper Miocene to Pliocene of the Gulf of Mexico (as Tectatodinium sp. B in Wrenn and Kokinos, 1986), from the upper Miocene (Amaurolithus primus nannofossil Zone) of Site 502, Caribbean Sea (as Tectatodinium sp. B of Wrenn and Kokinos, 1986; J. Wrenn, pers. comm. to M.J.H., 1986), and occurs commonly from the middle and lower upper? Miocene of Baffin Bay (Head et al., c, this volume,).

Genus HYSTRICHOKOLPOMA Klumpp, 1953 emend. Williams and Downie, 1966

Hystrichokolpoma rigaudiae Deflandre and Cookson, 1955.

Remarks. Only one specimen was observed and this occurred in the lower part of assemblage Zone HNM2 at Site 646. This species also has its last occurrence in the lower upper Miocene at Sites 642 and 643 in the Norwegian Sea (Mudie, in press), in the lower upper Miocene of the Scotian Shelf/Grand Banks wells (Williams and Bujak, 1977b), and the upper Miocene of the northwest European continental shelf (Harland, 1978). H. rigaudiae occurs rarely throughout the lower to middle (and lower upper?) Miocene of Baffin Bay (Head et al., c, this volume), and 
has been recorded from the Miocene (see "Other Miocene Palynological Studies" section, Head et al., c, this volume, for discussion of age) of the Beaufort Sea (Dixon et al., 1984). H. rigaudiae ranges into the Pliocene of northern Italy (Habib, 1971), and Pleistocene of both Israel (Rossignol, 1962, 1964) and the Gulf of Mexico (Wrenn and Kokinos, 1986). In the western and northern Pacific, $H$. rigaudiae has a top range in the lower Pleistocene and its local disappearance during the end of the early Pleistocene in the northern Japan area has been attributed to possible oceanographic changes associated with Northern Hemisphere cooling (Bujak and Matsuoka, 1986a). We suggest that the truncated upper range of $H$. rigaudiae in the northern North Atlantic and adjacent areas is associated with late Miocene cooling.

Sarjeant (1983) provided a comprehensive synonymy for $H$. rigaudiae and gave a range of upper Paleocene to Holocene.

\section{Genus IMPAGIDINIUM Stover and Evitt, 1978}

Impagidinium aculeatum (Wall, 1967) Lentin and Williams, 1981

Impagidinium sp. cf. I. aculeatum (Wall, 1967) Lentin and Williams, 1981

(Pl. 2, Fig. 15)

Remarks. These specimens differ from I. aculeatum in having longer gonal spines and lower interconnecting parasutural crests than for $I$. aculeatum. A similar morphotype with large gonal spines was observed in sediments of lower upper Miocene age at Site 611 (Mudie, 1987).

\section{Impagidinium fenestroseptatum $\mathrm{Head}$ et al. (b, this volume)}

Remarks. Specimens similar to $I$. fenestroseptatum are referred to as Cyst type 1 by de Vernal and Mudie (a, this volume). Cyst type 1 is abundant in lower Pliocene sediments at Site 646.

\section{Impagidinium paradoxum (Wall, 1967) Stover and Evitt, 1978}

$$
\text { (Pl. 2, Figs. 1-6) }
$$

Impagidinium patulum (Wall, 1967) Stover and Evitt, 1978 sensu lato (Pl. 2, Figs. 11 and 16)

Remarks. Specimens in this study vary considerably in size, from 45 to $91 \mu \mathrm{m}$, and larger forms generally have a more robust ornament. Edwards (1984b) noted a similarly wide size range $(40-110 \mu \mathrm{m})$ from the Miocene of the Rockall Plateau, and large specimens $(>80 \mu \mathrm{m})$ also characteristically occur in sediments of lower to middle Miocene age in the Norwegian Sea (Mudie, in press) and in the lowermost Miocene interval at DSDP Site 611 (P. Mudie, unpubl. data, 1987). The more robust forms may be restricted to the lower part of the interval studied (dinocyst assemblage Zones HNM1 to HNM3). More research will be necessary to characterize this group in a meaningful way.

\section{Impagidinium? pallidum Bujak, 1984}

(Pl. 2, Fig. 20; Pl. 7, Fig. 5)

Remarks. The paratabulation of this species is not fully understood, and the generic assignment proposed by Bujak thus is in question, following Mudie (1987). I.? pallidum has been recorded from the northernmost Pacific and Bering Sea (Bujak, 1984), Beaufort Sea (as "Impagidinium sp. A" in both Bujak and Davies, 1981; and Dixon et al., 1984), Arctic Ocean (Mudie, 1985; Aksu and Mudie, 1985a), northern North Atlantic (Mudie, 1987), Norwegian Sea (Manum et al., in press; Mudie, in press), Labrador Sea (Head and Norris, this volume; de Vernal and Mudie, a, this volume), and Baffin Bay (Head et al., c, this volume). Its lowest known occurrences are from the middle Eocene of the Labrador Sea (Site 647, Head and Norris, this volume), and upper Eocene of the northernmost Pacific area (Bujak, 1984), and its highest occurrence is in the Pleistocene of the Norwegian Sea (Mudie, in press). It is now common in surface sediments of the Arctic Ocean (Mudie, pers. obs.). This species was evidently cold tolerent and well adapted to a boreal environment. Its presently known distribution suggests that it may be a useful indicator of cool-temperate or boreal watermasses.

\section{Impagidinium sp. 1}

(Pl. 2, Figs. 7-10 and 12-14)

Dimensions. Range of length (including crests): $36(41.6) 48 \mu \mathrm{m}$; maximum crest height, 4 to $7 \mu \mathrm{m}$. Twelve specimens were measured.
Description. Cyst body ovoidal with a smooth to faintly granulated wall. Crests have straight to concave tops, and are highest at gonal junctions, giving the cyst a polygonal outline. Crest tops are irregularly serrated and sometimes have a ragged profile. Paratabulation appears typical for the genus. There is little expression of tabulation within the parasulcal region. Some similarities may exist between this species and specimens referred to as both I. japonicum and I. strialatum from Pliocene to Pleistocene sediments at DSDP Site 611 (Mudie, 1987) and at ODP Site 647 (de Vernal and Mudie, a, this volume). I. japonicum is also common in Pliocene to lower Pleistocene sediments at ODP Site 646 (de Vernal and Mudie, a, this volume) and at the base of the upper Pliocene at Site 645 (de Vernal and Mudie, b, this volume). However, these taxa have not been recorded from high-latitude Miocene sediments, and apparently, Impagidinium sp. 1 is sufficiently distinct to warrant specific recognition. This species was questionably recorded sporadically (as Impagidinium sp. 7) from the Miocene of Site 645, Baffin Bay (Head et al., c, this volume).

\section{Impagidinium sp. 2 \\ (Pl. 2, Fig. 19)}

Remarks. This species is similar to the larger, more robust forms of I. patulum; however, it differs in details of sulcal paratabulation. Although only recorded with certainty from a single sample, this species may have been included with robust forms of $I$. patulum in other samples from the lower dinocyst assemblage zones of this hole.

\section{Genus INVERTOCYSTA Edwards, 1984}

Remarks. Invertocysta and the related genus Amiculosphaera Harland, 1979 differ in the extent to which the endophragm and periphragm are detached on the hypocyst. Invertocysta has the endophragm separated from the periphragm over most of the hypocyst, except midventrally, while in Amiculosphaera, the endophragm and periphragm are attached over much of the hypocyst, including the antapex (Harland, 1979; see also SEM illustration in Harland, 1988b, pl. 81, Figs. 5 and 6). An apical, funnel-shaped process supports the periphragm on Amiculosphaera, and this feature may be present on some specimens of Invertocysta (e.g., I. lacrymosa, Edwards, 1984, Pl. 3, Figs. 4a, 4b, 5).

Two species presently comprise this genus, $I$. tabulata (the type) and I. lacrymosa. Specimens that, with varying degrees of certainty, may be referred to this genus have been recorded from the Norwegian Sea (as "T. delicata" in Manum, 1976; as I. lacrymosa, and I. tabulata in Manum et al., in press; I. lacrymosa, I. tabulata, and Invertocysta spp. in Mudie, in press) from Europe (as "Thalassiphora sp. cf. T. pelagica" in Habib, 1971; as " $T$. delicata sensu Manum 1976" in Costa, 1980; Powell, 1986b, 1986c; Herngreen, 1987), from the Bay of Biscay (as " $T$. delicata" in Harland, 1978, 1979), from the central North Atlantic (Edwards, 1984b; Mudie, 1987; as Forma A = "Thalasiphora delicata" in Costa and Downie, 1979; and as A. umbraculata in Brown and Downie, 1985), from Site 645, Baffin Bay (Head et al., c, this volume), from the Gulf of Mexico (Wrenn and Kokinos, 1986; Duffield and Stein, 1986a), and from the western Caribbean Sea (J. H. Wrenn, pers. comm. to M.J.H., 1986). These records indicate a range of upper Oligocene (Manum, 1976; Costa and Downie, 1979) to upper Pliocene (Mudie, 1987 and in press; de Vernal and Mudie, a, this volume) for the North Atlantic and contiguous areas, and a range into the upper Pliocene or lowermost Pleistocene in the Gulf of Mexico (Wrenn and Kokinos, 1986). These records and this study support an outer neritic to oceanic ecological designation given by Wrenn and Kokinos (1986). The disappearance of Invertocysta spp. from the North Atlantic region by or during late Pliocene time probably relates to the onset of Northern Hemisphere glaciations, hence its possibly prolonged survival in the tropical Gulf of Mexico. We note that this conspicuous taxon has not previously been recorded from the Pacific Ocean.

\section{Invertocysta lacrymosa Edwards, 1984}

$$
\text { (P1. 4, Fig. 6) }
$$

Remarks. This species was first described from the top middle? and lower upper Miocene of DSDP Hole 555, Rockall Plateau (see "Other Miocene Palynological Studies" section in Head et al., c, this volume for discussion of age) and has a known range of middle Miocene (Mudie, in press) to upper Pliocene (as "T. delicata" in Harland, 1979; de Vernal and Mudie, a, this volume) or lowermost Pleistocene? (Wrenn and Kokinos, 1986). 
Invertocysta spp.

(Pl. 4, Figs. 3, 5, 7-9)

Remarks. This group consists of specimens that are folded or poorly oriented (see also Mudie, 1987) and that may belong to I. lacrymosa and other related species. Some specimens assigned to this group may belong to Amiculosphaera umbracula Harland. Size ranges from 50 to $94 \mu \mathrm{m}$. Wall surface is smooth to shagreenate and does not possess the prominent paratabulation of $I$. tabulata Edwards 1984b. Note that $A$. umbraculata is absent from the Pacific and northwestern North Atlantic, whereas it is common in Pliocene sediments of the eastern North Atlantic and Norwegian Sea (Mudie, in press). Another morphotype, Invertocysta sp. 1, which has a relatively large endocyst and well-defined ventral paratabulation, is common in the lower Pliocene sediments at Site 646 (de Vernal and Mudie, a, this volume).

\section{Genus LABYRINTHODINIUM Piasecki, 1980}

Labyrinthodinium truncatum Piasecki, 1980

$$
\text { (Pl. 1, Figs. 25, 26) }
$$

Dimensions. Range in central body diameter, $24(25.6) 28 \mu \mathrm{m}$. Process length ranges from about 5 to $7 \mu \mathrm{m}$. Seven specimens were measured.

Remarks. This species has been reported from the lower Miocene of Baffin Bay (Head et al., c, this volume), middle Miocene of Denmark (Piasecki, 1980), Holland (Herngreen, 1987), Norwegian-Greenland Sea region (Mudie, in press; Manum et al, in press; and as "Cordosphaeridium sp. II" in Manum, 1976), South Carolina in the United States (Edwards, 1986, p. 50-correlated to East Coast diatom Zone 6 [approximately 12.25-13.0 Ma] of Andrews, 1978), British Southwestern Approaches (Powell, 1988, correlated to foraminifer Zone Nll, from Evans and Hughes, 1984), upper middle and lower upper Miocene (nannofossil Zones NN7 or NN8 to NN9 or NN10, Backman, 1984) of Site 555, Rockall Plateau (Edwards, 1984b), and middle or upper Miocene of the Gulf of Mexico (Wrenn and Kokinos, 1986). The identification of L. truncatum in upper Miocene and Pliocene sediments at Sites 611 and 607 (Mudie, 1987) was incorrect (see "Remarks" for Cymatiosphaera? invaginata).

L. truncatum has a known range of upper? lower Miocene (Head et al., c, this volume; see also discussion therein) to lower upper Miocene (nannofossil Zone NN9 or NN10, Edwards, 1984b; Manum et al., in press; nannofossil Zone NN10, this study). Note that $L$. truncatum has not been recorded from the Pacific region.

\section{Genus LEJEUNECYSTA Artzner and Dörhöfer, 1978}

\author{
Lejeunecysta sp. cf. L. tenella (Morgenroth, 1966) Wilson and \\ Clowes, 1980 \\ (Pl. 3, Figs. 5, 6, 8)
}

Dimensions. Range in cyst length, 47(49.5)54 $\mu \mathrm{m}$; cyst width, $40(43.5) 48 \mu \mathrm{m}$. Thirteen specimens were measured.

Description. Autophragmal peridinioid cysts. Surface smooth to faintly granulated, with short, solid spines scattered sparsely over the epicyst and hypocyst. Spines are broad-based, from 1 to $2 \mu \mathrm{m}$ high, and often have concave sides. On the epicyst, spines are frequently aligned in two pairs of rows that are sometimes situated on low folds (comparable with the crests on the epicyst of $C$. cristatoserratum). Spines often occur in small aligned groups of two or three. On the hypocyst, some degree of alignment of spines is usually seen. Antapical horns are of approximately equal size and taper to small, solid, aculeate tips. Cingulum planar, with a wide sulcal area, and margins delineated by low folds that bear short, solid spines. Cingular folds are often discontinuous and indicate paratabulation. Of the 15 specimens observed, seven were dorsoventrally compressed, three were subdorso-ventrally compressed, and five were obliquely compressed (at about $45^{\circ}$ to polar axis).

Remarks. This morphotype differs from $L$. tenella in often possessing discontinuous folds along the paracingulur margins that reflect tabulation.

L. tenella is known from the lower Oligocene (Morgenroth, 1966) to upper Oligocene (Benedek, 1972) of Germany, and from the Oligocene to mid-Miocene of the southeastern North Atlantic (as "Vozzhennikovia tenella" in Williams, 1978).
Lejeunecysta spp.

(Pl. 3, Figs. 13, 15)

Remarks. This group requires further systematic work and mainly is composed of several species of between 55 and $100 \mu \mathrm{m}$ in length, with aculeate apical and antapical horns. Lejeunecysta fallax (Morgenroth) Artzner and Dörhöffer, 1978 is included within this group.

\section{Genus LINGULODINIUM Wall, 1967 emend. Wall and Dale, 1973 \\ Lingulodinium machaerophorum (Deflandre and Cookson, 1955) Wall, 1967}

Remarks. The scarcity of $L$. machaerophorum in the upper Miocene of Site 646 contrasts with its fairly consistent occurrence in the upper Miocene of the Rockall Plateau (Edwards, 1984b), Norwegian Sea (Manum et al., in press; Mudie, in press), and Gulf of Mexico (Wrenn and Kokinos, 1986). Today's distribution of $L$. machaerophorum (Harland, 1983 ) indicates it is a warm-water euryhaline species. Its diachronous last occurrence across the east Canadian shelf (Williams and Bujak, 1977a), ranging from upper Miocene (Grand Banks) to lower upper Miocene (Labrador Shelf) to lower middle Miocene (Scotian Shelf), may reflect a displacement of direct Gulf Stream influence across offshore eastern Canada during the middle to late Miocene, a factor that could be responsible for the scarcity of this species at Site 646 .

\section{Genus MELITASPHAERIDIUM Harland and Hill, 1979}

Melitasphaeridium choanophorum (Deflandre and Cookson, 1955) Harland and Hill, 1979 emend. Harland and Hill, 1979

$$
\text { (P1. 6, Figs. 9, 10) }
$$

Remarks. Specimens of Melitasphaeridium in this study have a finely granulated wall surface and narrow hollow processes although one specimen was found to have at least one broad-based tapering process (as in Melitasphaeridium asterium, Eaton, 1976). These specimens have process terminations varying from broad platforms having serrated margins (as in the holotype of $M$. choanophorum) to margins bearing fewer and longer aculeae (as in M. asterium Eaton, 1976, although this species differs in having a smooth wall). Harland and Hills (1979) found a similar variation and emended $M$. choanophorum to include both types of process termination. While this variation in Neogene assemblages is probably intraspecific, there may be some merit in distinguishing between morphotypes with aculeate margins and those with serrated margins ( $M$. choanophorum sensu stricto) since the latter appears to make a later appearance in the stratigraphic record (see Bujak, 1980, p.30). We consider $M$. choanophorum sensu stricto to range from the lower Oligocene (Rupellian as $H$. pseudorecurvatum in Benedek, 1972) to lower Pleistocene of the Norwegian Sea (Mudie, in press) and upper Pleistocene of the Gulf of Mexico (Wrenn and Kokinos, 1986).

$M$. choanophorum was only occasionally observed in upper Miocene sediments at Site 646, was not found in younger sediments at either this site or Site 647, Labrador Sea (de Vernal and Mudie, a, this volume), and was not observed at DSDP Site 611, northern North Atlantic (Mudie, 1987) nor at ODP Site 645, Baffin Bay, with the exception of a rare occurrence in the lower Miocene (Head et al., c, this volume). This stratigraphic distribution suggests that this species, which is common in Miocene to lower Pliocene sediments in most North Atlantic areas, may be a good indicator of relatively warm surface water.

Genus MURATICYSTA Head et al. (b, this volume) Muraticysta microornata Head et al. (b, this volume)

Genus NEMATOSPHAEROPSIS Deflandre and Cookson, 1955 emend. Williams and Downie, 1966

Nematosphaeropsis labyrinthea (Ostenfeld, 1903) Reid, 1974 Nematosphaeropsis lemniscata Bujak, 1984

(Pl. 6, Figs. 4,8,11)

Remarks. This species is considered to differ from $N$. labyrinthea (Ostenfeld, 1903) in having solid, narrow, ribbonlike trabeculae, rather than the threadlike trabeculae of the latter, although it is evident that $N$. labyrinthea needs to be reevaluated. Specimens from Site 646 have a scabrate wall surface, hollow processes bearing hollow trifurcate, and secondarily bifurcate terminations, the ends of which bear a pair of solid ribbonlike trabeculae about $2 \mu \mathrm{m}$ wide. A wide range in overall diameter 
and proportional size of the central body was observed and probably reflects ecophenotypic variation. A comparable situation may exist for the extant species, $N$. labyrinthea, which was recorded in large and small forms by Wall et al. (1977, as $N$. balcombiana). N. lemniscata had a wide geographic distribution during the late Miocene and has been recorded from Japan, northern Pacific, Bering Sea, Beaufort Sea, Grand Banks of Newfoundland (see Bujak, 1984; Bujak and Matsuoka, 1986a, 1986b), Norwegian Sea (Mudie, in press), central and northern North Atlantic (grouped together with the more abundant species $N$. labyrinthea, in Mudie, 1987), and eastern Pacific (as Cannosphaeropsis sp. A in Ballog and Maloy, 1981). N. lemniscata ranges from upper Oligocene to lower Pliocene in the northern and western Pacific and Bering Sea and is most common in these regions during the late Miocene and Pliocene (Bujak and Matsuoka, 1986a, 1986b; Matsuoka et al., 1987). The high-latitude occurrence of this species led Bujak (1984) to consider this species a cold-water form. Additional records, from the Miocene of Baffin Bay (Head et al., b, this volume), the North Atlantic (as N. labyrinthea in Edwards, 1984b and Mudie, 1987), Italy (Powell, 1986a, 1986c), and Gulf of Mexico (as N. labyrinthea in Wrenn and Kokinos, 1986) indicate that this species is cold tolerant and has a fairly broad thermal tolerance. Available records and morphologic variability, as discussed above, indicate that $N$. lemniscata is an outer neritic to oceanic species, and probably opportunistic, as has been suggested for N. labyrinthea by Wall et al. (1977). Present records indicate a range of Oligocene (Bujak and Matsuoka, 1986a, 1986b) to lower Pleistocene (Mudie, in press) or undifferentiated Pleistocene (as N. labyrinthea in Wrenn and Kokinos, 1986).

\section{Nematosphaeropsis major Head et al. (b, this volume)}

Nematosphaeropsis sp. A Wrenn and Kokinos, 1986

$$
\text { (P1. 5, Figs. 1-3) }
$$

Remarks. Two specimens were recorded during this study; these have overall diameters of 34 and $36 \mu \mathrm{m}$. Wrenn and Kokinos (1986) recorded this species from the middle or upper Miocene to Pleistocene of the Gulf of Mexico.

\section{Nematosphaeropsis sp. 1}

$$
\text { (Pl. 6, Figs. 12-14) }
$$

Dimensions. Range of overall cyst length is $41(48.4) 55 \mu \mathrm{m}$; central body length is $26(30.4) 36 \mu \mathrm{m}$. Eight specimens were measured.

Description. Central body is ellipsoidal with a granulate to scabrate surface. Processes are gonal, relatively short and hollow, with trifurcate and secondarily bifurcate terminations, linked by parallel pairs of threadlike trabeculae as typical for the genus. Process stems may be fairly broad proximally, and closely adjacent processes may coalesce at their bases. Paratabulation appears to be gonyaulacacean. The archeopyle is precingular, presumably by loss of paraplate $3^{\prime \prime}$.

Remarks. This is a distinctive species; it is distinguished from $N$. lemniscata by its threadlike (rather than ribbonlike trabeculae), short process length, and less numerous (apparent absence of intergonal) processes. Differences between Nematosphaeropsis sp. 1 and N. labyrinthea are difficult to determine owing to the poorly understood nature of the latter.

\section{Genus OPERCULODINIUM Wall, 1967}

Operculodinium? eirikianum Head et al. (b, this volume)

\section{Operculodinium centrocarpum (Deflandre and Cookson, 1955) Wall, 1967 sensu lato}

Description. Specimens range from 48 to $91 \mu \mathrm{m}$ in diameter (although most are between 50 and $65 \mu \mathrm{m}$ ) and have process lengths that range from about 5 to $10 \mu \mathrm{m}$. Wall thickness is from less than 1 to about $2 \mu \mathrm{m}$.

Remarks. Wall (1967), in a study of Quaternary dinocysts from the Caribbean, differentiated otherwise similar specimens that he assigned to 0 . centrocarpum (Deflandre and Cookson) and 0 . israelianum (Rossignol) by their relative process length, which was about one-fifth to onequarter of the central body diameter for $O$. centrocarpum, and about one-tenth or less for 0 . israelianum. Using Wall's distinction, some specimens in this study could be assigned to 0 . israelianum.

Observations of Miocene specimens assigned to $O$. centrocarpum from both the Rockall Plateau (Edwards, 1984b) and this study indicates considerable variability in size, with large specimens being present.
This large morphotype also was reported from the Miocene of the Caribbean (Wall, 1967) and offshore eastern Canada (Bujak, 1984), but was not encountered in Miocene sediments from the Bering Sea and northern North Pacific (Bujak, 1984).

O. centrocarpum is the cyst of the extant thecate species Protoceratium reticulatum (Claparédè and Lachmann) (also known as Gonyaulax grindleyi Reinecke) and has a long stratigraphic record extending into the Paleogene or earlier. $O$. centrocarpum is an inner neritic to oceanic species (Harland, 1983; Wrenn and Kokinos, 1986), and it may also be a pioneer species in north-temperate to arctic environments (Harland, 1983). High abundances reported in Miocene sediments from the Goban Spur were linked with marine transgressive phases by Brown and Downie (1985). $O$. centrocarpum has a cosmopolitan geographic distribution, although it is associated in particular with the North Atlantic Current (Williams, 1971; Harland, 1983) and has been related to climatic ameliorations in Quaternary sequences (Mudie, 1985; Harland, 1988a).

\section{Operculodinium janduchenei Head et al. (b, this volume)}

Remarks. See Head et al. (b, this volume) for synonymy. This species was first described and illustrated as "Operculodinium sp." by Jan du Chêne (1977) from the upper Miocene of Spain. It has also been recorded from the upper Miocene of the following localities: North Atlantic (Edwards, 1984b; Mudie, 1987); Norwegian Sea (Mudie, in press); western Caribbean Sea, DSDP Site 502 (Discoaster berggreni to upper Amaurolithus primus nannofossil zones; J.H. Wrenn, pers. comm. to M.J.H., 1986); and Gulf of Mexico (Wrenn and Kokinos, 1986, using the planktonic foraminifer Zones N17 and N19). The lowest recorded occurrences of $O$. janduchenei are apparently from the lower Miocene (planktonic foraminifer Zones N5 to N7) and middle Miocene (planktonic foraminifer Zone N11, from Evans and Hughes, 1984) of the British Southwestern Approaches (Powell, 1988). However, at DSDP Site 555 , Rockall Plateau, 0 . janduchenei has a lowest occurrence approximately within nannofossil Zone NN8 of latest middle Miocene through earliest late Miocene age (Edwards, 1984b; see "Other Miocene Palynological Studies" section in Head et al, c, this volume, for discussion of age). It also occurs in the lower upper Miocene at DSDP Site 611, northern North Atlantic (Mudie, 1987, correlating to nannofossil Zones NN9 and NN9? from Takayama and Sato, 1986). The species has a highest occurrence in the upper Pliocene of DSDP Site 611, northern North Atlantic (Mudie, 1987) and upper Pliocene of the Norwegian Sea (Mudie, in press).

$O$. janduchenei appears to be an outer neritic to oceanic species, according to its recorded distribution and from this study. It has not been recorded outside the North Atlantic and adjacent areas and the Norwegian Sea, and is notably absent from Miocene Pacific assemblages (Matsuoka, 1983; Bujak and Matsuoka, 1986a; Matsuoka et al., 1987).

$$
\begin{aligned}
& \text { cf. Operculodinium sp. of Piasecki, } 1980 \\
& \text { (Pl. 1, Figs. 7,8,16) }
\end{aligned}
$$

Dimensions. Range in cyst length is 25 to $34 \mu \mathrm{m}$, ornament about 1.0 to $1.5 \mu \mathrm{m}$ high. Six specimens were measured.

Description. This is a small, ellipsoidal species, with smooth wall and short, essentially solid (there may be some minute proximal vacuities) processes. These processes vary from flat-topped bacculae to truncated cones and have bases with irregular outlines in plan view.

Remarks. This species differs from Operculodinium sp. of Piasecki, 1980, (also as Operculodinium sp. Piasecki, 1980, in Edwards, 1984b) only in its smaller size (length, 33-39 $\mu \mathrm{m}$ in Piasecki, 1980; $47 \mu \mathrm{m}$ from the illustration in Edwards, $1984 \mathrm{~b} ; 36 \mu \mathrm{m}$ from the illustration in Wrenn and Kokinos, 1986). ?Pyxidiella cf. scrobiculata (Deflandre and Cookson) Cookson and Eisenack, 1958 of Harland (1979) differs in having a less-pronounced ornament, larger size, and apparently intercalary archeopyle. Operculodinium sp. of Piasecki, 1980 ranges through the upper Miocene Gram Clay of Denmark (Piasecki, 1980), occurs in the middle or upper Miocene and Pliocene of the Gulf of Mexico (Wrenn and Kokinos, 1986), and may have a useful range top within the upper Miocene of the Rockal Plateau (Edwards, 1984b). Operculodinium sp. of Piasecki, 1980 has also been recorded from the lower to upper Miocene of the Norwegian Sea (Mudie, in press), from the lower Miocene of the British Southwestern Approaches (Powell, 1988, correlated to foraminifer Zones N5-N7 and N8, from Evans and Hughes, 1984), and from the upper Miocene (Discoaster berggreni nannofossil Zone) of DSDP Site 502, western Caribbean Sea (J.H. Wrenn, pers. comm. to M.J.H., 1986). Operculodinium sp. B of Powell, 1986c appears similar, except for the 
finely granulate wall surface. This species was recorded from the upper Miocene of the Castellanian stratotype of northwest Italy (Powell, 1986c).

$$
\begin{gathered}
\text { Genus PARALECANIELLA Cookson and Eisenack, } 1955 \\
\text { emend. Elsik, } 1977
\end{gathered}
$$

Paralecaniella indentata (Deflandre and Cookson, 1955) Cookson and Eisenack emend. Elsik, 1977

Remarks. $P$. indentata is a common component of some shelf and restricted marine assemblages during the Paleogene. The rather poor preservation of specimens at Site 646 suggests that these may be reworked or transported. $P$. indentat $a$ has been recorded from the Maestrichtian of Holland (Herngreen et al., 1986) to the middle and lower upper? Miocene of Site 645, Baffin Bay (Head et al., c, this volume), upper Miocene of offshore eastern Canada (Williams and Bujak, 1977b), upper Miocene (Tortonian), of Holland (Herngreen, 1987), and Miocene? of Australia (Deflandre and Cookson, 1955).

Genus PENTADINIUM Gerlach, 1961 emend. Benedek et al., 1982

Pentadinium laticinctum laticinctum Gerlach, 1961 emend. Benedek et al., 1982

$$
\text { (PI. 7, Fig. 6) }
$$

Remarks. A single specimen was recorded during this study. Elsewhere, this species ranges at least into the middle Miocene, and at Site 645, Baffin Bay, has a last occurrence in the middle or lower upper Miocene. There are a number of upper Miocene occurrences (Edwards, 1984b, correlated to nannofossil Zones NN9 or NN10, in Backman, 1984; Brown and Downie, 1985 correlated to nannofossil Zone NN11, in Müller, 1985; Powell, 1986c, correlated to foraminifer Zone N16; Herngreen, 1987, Tortonian), although reworking may account for some of these (see discussion and additional records in Powell, 1986c, p. 135).

\section{Genus POLYKRIKOS Bütschli, 1873 \\ Cysts? of Polykrikos? \\ (Pl. 3, Fig. 4)}

Remarks. This cyst? type, although not well preserved, compares with cysts of the extant colonial dinoflagellate Polykrikos schwartzii Bütschli, 1873 (see Harland, 1981). Cyst? length ranges from 68 to $105 \mu \mathrm{m}$. Cysts of Polykrikos schwartzii are known from Quaternary sediments, and cysts referrable to Polykrikos were recorded from the upper Oligocene of South Carolina (Ford, 1979, cited in Goodman, 1987, p. 668). Related forms may occur in the Mesozoic (see Harland, 1981, for discussion).

\section{Genus POLYSPHAERIDIUM Davey and Williams, 1966 emend. Bujak et al., 1980 \\ Polysphaeridium? sp. 1 (Pl. 7, Fig. 3)}

Remarks. These cysts are large, thin-walled, and have a possible epicystal archeopyle. Processes are long and slender, with aculeate terminations. Processes appear septate because of distinctive and regularly spaced internal annular thickenings along the length of process stems. A similar feature occurs in some undescribed species of Sumatradinium (M. Head, pers. obs.)

Genus PYXIDIELLA Cookson end Eiseneck, 1958

Pyxidiella? sp. 1

(Pl. 1, Figs. 13-15)

Dimensions. Range of cyst length, 29 to $34 \mu \mathrm{m}$. Processes up to 2 $\mu \mathrm{m}$ long. Nine specimens were measured.

Description. Small, broadly ellipsoidal cysts, with a smooth to granulate wall and precingular archeopyle. Processes are short and more or less solid, rounded, nontabular cones. Two specimens having granulate walls and low (1 $\mu \mathrm{m}$ high), rounded, solid verrucae also were included in this group.

Remarks. This species differs from $O$. janduchenei $\mathrm{n}$. $\mathrm{sp}$. in having solid processes. The illustrated specimen (Pl. 1, Figs. 13-15) appears to have an intercalary archeopyle, although archeopyle type in other specimens is uncertain, but possibly precingular.
Genus RETICULATOSPHAERA Matsuoka, 1983 emend. Bujak and Matsuoka, 1986b

Reticulatosphaera actinocoronata (Benedek)

Bujak and Matsuoka, 1986b

(Pl. 6, Fig. 5)

Remarks. This species has also been recorded in the literature as ?Cannosphaeropsis sp. B of Shimakura et al., 1971, Cannosphaeropsis sp. A Williams and Brideaux, 1975, ?Cannosphaeropsis sp. 1 (Mudie, 1987; Mudie, in press), and Impletosphaeridium sp. 1 Manum, 1976. Complete synonymies and occurrences are provided by Matsuoka (1983), Edwards (1984b), Bujak (1984), and Bujak and Matsuoka (1986b). Additional records (under various synonyms) are given in Williams (1978), Piasecki (1980), Brown and Downie (1985), LeNoir and Hart (1986), Matsuoka et al. (1987), Herngreen (1987), El Beialy (1988a, 1988b), Powell (1988), Head and Norris (this volume), Head et al. (c, this volume), and de Vernal and Mudie, (a, b, this volume). The species also may have been recorded from the upper Oligocene or Miocene of South Australia (as "Adnatosphaeridium sp." in Truswell et al., 1984, Fig. 11, I to L). It has been reported widely in the Miocene of the Atlantic and occurs often in the Miocene of Site 645, Baffin Bay (Head et al., c, this volume) and in the upper Miocene of the Beaufort Sea (Dixon et al., 1984), although it is rare in the Bering Sea (Bujak and Matsuoka, 1986b). These records suggest a fairly wide ecological and thermal tolerance for this species during the late Miocene. $R$. actinocoronata ranges from the upper Eocene (nannofossil Zones NP18/NP20) of Site 647, Labrador Sea (Head and Norris, this volume) and upper lower? Oligocene (nannofossil Zones NP23-NP24) of the Rockall Plateau (Costa and Downie, 1979), to the upper Pliocene of the western and northern Pacific (Bujak and Matsuoka, 1986a; Matsuoka et al., 1987), or locally extending into the lower Pleistocene of Japan (Matsuoka, 1983). Its highest occurrence in the lower Pliocene at Site 646 (de Vernal and Mudie, a, this volume, correlates well with its highest occurrence in the lower Pliocene (nannofossil Zone NN13) of DSDP Site 611 in the northern North Atlantic, (Mudie, 1987); in the lower Pliocene of DSDP Site 607 (lower nannofossil Zone NN14) in the central North Atlantic (Mudie, 1987); and the lower Pliocene of the Norwegian Sea (Mudie, in press). This suggests a stratigraphically useful last occurrence datum for the lower Pliocene of the North Atlantic region that may also correlate with the last abundant occurrence in the lower Pliocene of Japan (Matsuoka et al., 1987).

Genus SELENOPEMPHIX Benedek, 1972 emend. Bujak et al., 1980 Selenopemphix dionaeacysta Head et al. (b, this volume)

Remarks. This species has previously been recorded from the upper lower to upper Miocene of the Gulf of Mexico (as Selenopemphix sp. A and sp. B in Duffield and Stein, 1986a), from the upper Miocene (Discoaster berggreni nannofossil Zone) of DSDP Site 502, Caribbean Sea (as Selenopemphix sp. B of Duffield and Stein, 1986; J.H. Wrenn, pers. comm. to M.J.H., 1986) and from the middle to uppermost Miocene of northwest Italy (as Xandarodinium? sp. cf. X. variabile in Powell, 1986c).

Selenopemphix nephroides Benedek, 1972 emend. Bujak, 1980

Remarks. Variable preservation of specimens assigned to this group suggests reworking of some specimens. A small morphotype (about 38 $\mu \mathrm{m}$ ) was recorded (rare/common) from Sample 105-646B-50X, CC.

\section{Selenopemphix sp. 1}

(Pl. 3, Figs. 2,7,8)

Description. Polar compressed with indistinct apical horn centrally located. Paracingular margins extended into lobate folds (reduced in one specimen) upon which are crests with straight to serrated distal edges and inwardly curving ends. The crested paracingular lobes (numbering 11 ? in total) presumably represent pre- and post-cingular paraplates. Two specimens were found.

Remarks. This species was recorded as "Xandarodinium? sp. cf. $X$. xanthum Reid, 1977" in Powell (1986c) from the upper Miocene (Tortonian) of northwest Italy. 


\section{Selenopemphix sp. 2}

(Pl. 3, Fig. 9)

1986a Selenopemphix sp. C; Duffield and Stein, PI. 1, Fig. 6 ? 1986a Selenopemphix sp. cf. Selenopemphix sp. A; Powell, Pl. 7, Fig. 10

Remarks. Cyst diameter varies from 44 to $53 \mu \mathrm{m}$. Spines on paracingular crests are about 1.5 to $2.0 \mu \mathrm{m}$ high, solid and acuminate. This species has been recorded from the late middle Miocene of the Gulf of Mexico (Duffield and Stein, 1986a) and questionably from the late Oligocene of northwest Italy (Powell, 1986a).

Selenopemphix? indentata Head et al. (b, this volume)

Genus SPINIFERITES Mantel, 1850 emend. Sarjeant, 1970

Spiniferites sp. cf. S. ellipsoideus Matsuoka, 1983

(Pl. 5, Fig. 5)

Remarks. A single specimen was found. Bujak and Matsuoka (1986a) considered $S$. ellipsoideus a possible ancestral form within their morphogenetic series of the Spiniferites elongatus Group, which has a range of lower Miocene to lower Pliocene in the northern and western Pacific (Bujak and Matsuoka, 1986a).

\section{Genera SPINIFERITES/ACHOMOSPHAERA}

Spiniferites/Achomosphaera Group.

Remarks. This group was not differentiated and comprises medium to small, thin-walled forms.

\section{Genus SURCULOSPHAERIDIUM Davey et al. emend. Davey, 1982}

\section{Surculosphaeridium sp. of Duffield and Stein, 1986}

$$
\text { (Pl. 6, Fig. 15) }
$$

Remarks. This species has been recorded from the lower to lower middle Miocene of the Gulf of Mexico (Duffield and Stein, 1986a) and upper lower Miocene of offshore Louisiana (as Dinocyst VI of LeNoir and Hart, 1986) and from the late Oligocene (nannofossil Zone NP24) of Site 647, Labrador Sea (Head and Norris, this volume). Site $646 \mathrm{spec}-$ imens resemble $S$. longifurcatum of Williams and Brideaux (1975) from the Santonian of the Grand Banks, eastern Canada. S.? longifurcatum was recorded (as suspected reworked specimens) from the Pleistocene of the Gulf of Mexico (Wrenn and Kokinos, 1986). S.? longifurcatum has a range of lower Albian to upper Campanian (Williams and Bujak, 1985). We are not sure whether the late Cenozoic occurences described above represent reworking.

\section{Genus TECTATODINIUM Wall, 1967 \\ Tectatodinium pellitum Wall, 1967}

Genus TUBERCULODINIUM Wall, 1967 emend. Wall and Dale, 1971

Tuberculodinium vancampoae (Rossignol, 1962) Wall, 1967

$$
\text { (Pl. 7, Fig. 14) }
$$

Remarks. T. vancampoae was recorded only as isolated specimens in this study. This species has a known range of lower Oligocene (from the Nile Delta, Egypt; El Beialy, 1988a) to Holocene and has a lowest occurrence in the upper Oligocene (corresponding to nannofossil Zones NN24/ NN25) of the North Atlantic region (Costa and Downie, 1979; Edwards, 1984a). However, this species possibly ranges into the uppermost middle Eocene (Wrenn and Damassa, 1988), or lower Eocene (Fechner and Mohr, 1986, 1988). T. vancampoae is known to be a useful indicator of tropical to warm-temperate conditions, based on its modern distribution in the Atlantic (Wall et al., 1977; Harland, 1983) and Pacific (Matsuoka, 1985a, 1985b, 1985c), and from its fossil record, which shows a poor high-latitude representation from Pliocene time and later, that can be attributed to the onset of cooling (Bujak, 1984). Matsuoka (1985c) showed that this species was the cyst form of the living dinoflagellate Pyrophycus steinii (Schiller) Wall and Dale, 1971. Today, it is a frequent component of tropical and subtropical estuaries (Wall et al., 1977) and is rare or absent from deep-water assemblages of the North Atlantic (Harland, 1983). Brown and Downie (1985) thus explained the presence of $T$. vancampoae in Miocene deeper-water assemblages of the Goban
Spur as probably owing to the flushing of estuaries during floods. A similar mechanism of transport may be responsible for the occasional occurrence of $T$. vancampoae from this study. However, $T$. vancampoae may have occupied a broader ecological environment during the Miocene as it is common to abundant in sediments of this age in the central North Atlantic and bathyal Norwegian Sea.

The morphology of $T$. vancampoae was discussed by Matsuoka (1985c) and has been reevaluated by Wrenn and Damassa (1988).

\section{Genus XANDARODINIUM Reid, 1977}

\section{Xandarodinium sp. $X$. variabile? Bujak, 1984}

(P1. 3, Fig. 1)

Remarks. Only four specimens were observed in this study, all from assemblage Zone HNM4 (samples from Sections 105-646B-62X-3 to $-66 \mathrm{X}-1$ ). The species also is rare in Pliocene sediments at this site (de Vernal and Mudie, a, this volume), with its last occurrence at the base of nannofossil Zone NN16 in the middle upper Pliocene. $X$. variabile was recorded from upper Miocene to lower lower Pleistocene of the Bering Sea/northern North Pacific region (Bujak, 1984), from the upper Miocene to lower Pleistocene of Japan (Matsuoka et al., 1987), and was recorded rarely in a single sample from the middle or upper Miocene of Baffin Bay (Head et al., c, this volume).

\section{Xandarodinium xanthum Reid, 1977}

$$
\text { (Pl. 3, Fig. 1) }
$$

Remarks. According to Reid (1977, p. 447), processes for this species may be simple, circular, or complex flanges with multifurcate tips. Specimens recorded here are quite variable in outline and have broad-based conical processes and solid, thickened tips that may bear a few blunt spines. These specimens resemble the holotype of $X$. xanthum, but the processes are quite different from those of the paratype (Reid, 1977, Pl. 3, Fig. 29). Turon and Londeix (1988, Pl. 4, Figs. 17,18) described specimens of $X$. xanthum from the Quaternary of the Mediterranean that compare with those of this study, but may have more complexly branched processes.

Specimens range from 51 to $64 \mu \mathrm{m}$ in diameter (including processes). $X$. xanthum seems restricted to assemblage Zone HNM1.

\section{DINOCYSTS OF UNKNOWN GENERIC AFFINITY}

Gen. et sp. indeterminate

(Pl. 4, Figs. 1,2,4; Pl. 6, Figs. 1-3,6,7)

In press Evittosphaerula? sp. 2 Manum et al., Pl. 7, Figs. 8-10

? 1986c Thalassiphora? sp. A Powell, Pl. 1, Fig. 4

Dimensions. Maximum diameter, 68(76.2)88 $\mu \mathrm{m}$. Eleven specimens were measured.

Description. Cyst having a skeletal appearance and circular to subcircular outline. Outer wall is made up of a wide periphragm network of rigid, arcuate, tangential trabeculae having a $\mathrm{T}$ or I cross section. Some trabeculae thicken toward intersections at one or two areas of the network. A very thin-walled, ovoid body of about one-third the overall diameter, with a faintly granulate surface, bears about four (?) radial processes that connect distally to the tangential network of trabeculae, but also appears to be directly connected to one of the thickened areas of the periphragm network.

Remarks. The thin central body is often absent or not well preserved, although the connecting processes with proximally attached fragments of the central body are usually present. SEM observations of some specimens revealed a line of small perforations occurring along the midline of the flattened outer crest of the trabeculae (see Pl. 6, Fig. 3). No specific paratabulation pattern was recognized.

An apparently conspecific form (recorded as Evittosphaerula? sp. 2 by Manum et al., in press) is common in a few samples of early late Miocene age at ODP Sites 642 and 643 in the Norwegian Sea (Manum et al., in press; Mudie, in press). A. J. Powell (pers. comm. to M.J.H., 1986) considers this form to be conspecific with his Thalassiphora? sp. A Powell, 1986c (also as ?Nematosphaeropsis sp. aff. N. "immensa," in Powell, 1983). Thalassiphora? sp. A is restricted to planktonic foraminifer Zone N16 from the Tortonian of the Castellanian stratotype of northwest Italy (Powell, 1986c) and bears some similarity to a form recorded by Powell from the lower Miocene (A. J. Powell, pers. comm. to M.J.H., 1986). Its last appearance (in Sample MAZ 13 of Powell, 1983) 
near the top of the Tortonian in northwest Italy compares favorably with the last common occurrence of Gen. et $\mathrm{sp}$. indet. of this study.

\section{Incertae sedis sp. 1 of Edwards, 1984b}

$$
\text { (PI. 5, Fig. 11) }
$$

Remarks. We could not determine the archeopyle style from the three specimens recorded here. Both precingular (Edwards, 1984b) and epitractal (Mudie, 1987) styles have been proposed.

This distinctive species was first recorded from DSDP Sites 554 and 555, Rockall Plateau (Edwards, 1984b), where it ranges from near the middle/upper Miocene boundary at Site 555 (correlated approximately within nannofossil Zone NN8, see "Other Miocene Palynological Studies" section in Head et al., c, this volume, for discussion of age) to lower upper Miocene (lower nannofossil Zone NN11, Backman, 1984). The species was recorded from sediments of similar age (nannofossil Zones NN9 through lower NN11) at DSDP Site 611, northern North Atlantic (Mudie, 1987) and from upper Miocene to lower Pliocene sediments (nannofossil Zones NN11 through NN14) at DSDP Site 607, central North Atlantic (Mudie, 1987). It also has been reported from the upper Miocene (Amaurolithus primus nannofossil Zone) to upper lower Pliocene (upper Sphaeroidinella dehiscens foraminifer Zone) of DSDP Site 502, western Caribbean Sea (J.H. Wrenn, pers. commn. to M.J.H., 1986), from the upper Miocene and lower Pliocene (foraminifer Zones N17 and N19) of the Gulf of Mexico (Wrenn and Kokinos, 1986), and from the upper Miocene of the west Florida carbonate platform (Wrenn and Satchell, 1988). At Site 646, the species ranges from upper Miocene to lowermost Pliocene (nannofossil Zones NN10 to NNI2). The stratigraphic range thus far known for this species is from near the middle/ upper Miocene boundary to lower Pliocene.

The presence of Incertae sedis sp. 1 of Edwards, 1984b at Site 646 supports the outer neritic to oceanic ecological classification proposed by Wrenn and Kokinos (1986) for this species. It appears to be a temperate to warm-water species, based on its presence in the Gulf of Mexico and its apparently truncated range-top at high-latitude North Atlantic DSDP Sites 555 and 611 and ODP Site 646.

\section{INCERTAE SEDIS INCLUDING ACRITARCHS}

\section{Genus CYMATIOSPHAERA (Wetzel, 1933) Deflandre, 1954}

\section{Cymatiosphaera? invaginata Head et al. (b, this volume)}

Remarks. Cymatiosphaera? invaginata is a dominant component of a number of samples in the interval studied. This species was recorded as "Labyrinthodinium truncatum" by Mudie (1987) from the upper Miocene and lower Pliocene of DSDP Sites 607 (central North Atlantic) and 611 (northern North Atlantic), and is common at Site 611. This cyst? form also occurs from the upper Miocene to upper Pliocene (common in Zone PM3 of upper Miocene to lowermost Pliocene) of the Norwegian Sea (as Cymatiosphaera sp. 1 in Mudie, in press), rarely from the middle Miocene or lower upper Miocene of Site 645, Baffin Bay (Head et al., c, this volume), and Pliocene to lowermost Pleistocene at Site 645, Baffin Bay (as Cymatiosphaera sp. in de Vernal and Mudie, b, this volume). Cymatiosphaera sp. (de Vernal and Mudie, a, this volume) is abundant in Pliocene sediments at Site 646, with a last occurrence in the lowermost Pleistocene interval.

\section{Acritarch sp. 1}

(Pl. 7, Figs. 4,8,9,12,13)

Dimensions. Range of maximum diameter (including crests), 19(23.1)30 $\mu \mathrm{m}$. Thirteen specimens were measured.

Description. Small, spherical cysts with two wall layers, having a thin, spherical, smooth, central body and an outer layer that is folded into a hamulate pattern of hollow crests. These crests are broadly triangular with an obtuse pointed crest top (apex) in cross section. The outer wall is thickened at the crest tops, and these are raised to a low point at crest intersections. Crests are about $3 \mu \mathrm{m}$ high. A large subcircular to subpolygonal opening that penetrates both inner and outer walls is often observed (see Pl. 1, Figs. 17,18,23,24). This acritarch may be the same as Incertae Sedis II of de Vernal and Mudie (a, this volume), which occurs throughout the Pliocene sediments at Site 646 and is occasionally present in upper Miocene through lower Pliocene sediments at Site 645 in Baffin Bay (de Vernal and Mudie, b, this volume).
Acritarch sp. 2

(Pl. 1, Figs. 19-22, 27-30)

Dimensions. Range in maximum diameter, including processes, 28(32)39 $\mu \mathrm{m}$. Twelve specimens were measured.

Description. Thin, spherical to ovoidal, central body with narrow stems and ridges that progressively expand distally to form a platform of interconnecting strips and patches of periphragm. The outer periphragm thus varies from fenestrate and continuous, to patchy with irregular trabeculae. Ridges and stems appear solid and finely spongy and/or granulate in optical section.

\section{Incertae sedis sp. 1 \\ (Pl. 3, Fig. 14)}

Remarks. We found a single cup-shaped? specimen having a striate surface and denticulate margin.

\section{Incertae sedis sp. 2 \\ (Pl. 5, Figs. 8,10)}

Remarks. A palynomorph having a thin membranous wall, made up of a larger, irregular-shaped body with large, simply branched lobes. Length is up to about $200 \mu \mathrm{m}$; morphology is highly variable. In some samples, there appears to be a morphologic intergradation with Rhizophagites sp. A of Wrenn and Kokinos (1986).

\section{Incertae sedis sp. 3}

(Pl. 5, Fig. 4)

Remarks. These are large, thin, smooth-walled, spherical protoperidinioid? cysts having a diameter of up to $80 \mu \mathrm{m}$. The wall may be lightly pigmented and is often finely wrinkled. We did not observe an archeopyle.

\section{Forma C Wrenn and Kokinos, 1986} (Pl. 5, Figs. 6,7)

Remarks. We found seven specimens in this study; these measure from 163 to $390 \mu \mathrm{m}$ long. This form has been recorded, abundantly in some samples, from the mid- or upper Miocene to Pleistocene of the Gulf of Mexico (Wrenn and Kokinos, 1986).

\section{Rhizophagites sp. A Wrenn and Kokinos, 1986}

Remarks. This species ranges from the middle or upper Miocene to the Pleistocene of the Gulf of Mexico, often occurring abundantly (Wrenn and Kokinos, 1986), and was recorded rarely from Paleogene sediments at Site 647, having a lowest occurrence in the middle Eocene (Head and Norris, this volume).

\section{ACKNOWLEDGMENTS}

Financial support for this project was obtained from a Natural Sciences and Engineering Research Council of Canada operating grant to G. Norris, from the Department of Energy, Mines, and Resources Research Agreement Nos. 66, 96, and 195 to G. Norris and M. J. Head, and from Geological Survey of Canada support for Project 820044 of P. J. Mudie. We thank G. Gomolka (Univ. of Toronto) for his assistance with the SEM and J. Dabros and K. MacNeil (Atlantic Geoscience Centre) for preparation of samples used by P. Mudie. We also thank G. Williams and R. Fensome for their hospitality during a visit by M. J. Head to the Bedford Oceanographic Institute, Nova Scotia, during this research; S. B. Manum (Univ. of Oslo) for making available to us a prepublication copy of ODP Leg 104 palynological results (Manum et al., in press), Anne de Vernal (Université de Québec à Montréal) for several opportunities to discuss and compare palynomorph taxa from ODP Legs 104 and 105, and M. A. Kaminski (Dalhousie Univ., Nova Scotia, formerly of Woods Hole Oceanographic Inst.) for valuable comments on an early draft of this paper and for fruitful discussions concerning late Miocene paleoceanography. We are especially grateful to L. I. Costa (Robertson Res. Int., Ltd., U.K.), M. A. Kaminski (Dalhousie Univ., Nova Scotia), S. P. Srivastava (Geological Survey of Canada), and an anonymous colleague, who reviewed this manuscript and provided many helpful comments.

This is Geological Survey of Canada contribution No. 35388 


\section{REFERENCES}

Taxonomic references before 1985 are not included here, and the reader is referred to Lentin and Williams (1985) for these.

Aksu, A. E., and Mudie, P. J., 1985a. Magnetostratigraphy and palynology demonstrate at least 4 million years of Arctic Ocean sedimentation. Nature, 318(6043):280-283.

1985b. Late Quaternary stratigraphy and paleoecology of northwest Labrador Sea. Mar. Micropaleontol., 9:537-557.

Andrews, G. W., 1978. Miocene diatom sequence in Miocene strata of the Chesapeake Bay region, Maryland. Micropaleontology, 24(4): 371-406.

Backman, J., 1984. Cenozoic calcareous nannofossil biostratigraphy from the northeastern Atlantic Ocean-Deep Sea Drilling Project Leg 81. In Roberts, D. G., Schnitker, D., et al., Init. Repts. DSDP, 81: Washington (U.S. Govt. Printing Office), 403-428.

Balch, W. M., Reid, P. C. and Surrey-Gent, S. C., 1983. Spatial and temporal variability of dinoflagellate cyst abundance in a tidal estuary. Can. J. Fish. Aquat. Sci., 40 (Suppl. 1): 244-261.

Baldauf, J. G., 1984. Cenozoic diatom biostratigraphy and paleoceanography of the Rockall Plateau region, North Atlantic, Deep Sea Drilling Project Leg 81. In Roberts, D. G., Schnitker, D., et al., Init. Repts. DSDP, 81: Washington (U.S. Govt. Printing Office), 439478.

Ballog, R. A., and Malloy, R. E., 1981. Neogene palynology from the southern Caifornia continental borderland, Site 467, Deep Sea Drilling Project, Leg 631. In Yeats, R. S., Haq, B. U., et al., Init. Repts. DSDP, 63:Washington (U.S. Govt. Printing Office), 565-576.

Barss, M. S., and Williams, G. L., 1973. Palynology and nannofossil processing techniques. Geol. Surv. Can. Pap., 73-26:1-25.

Benedek, P. N., 1972. Phytoplanktonen aus dem Mittel- und Oberoligozän von Tönisberg (Niederrheingebiet). Palaeontographica, Abt. B, 137:1-71.

1980. Vorläufige Ergebnisse der Phytoplankton-Untersuchungen aus dem nordwesteuropäischen Tertiärbecken. In Vinken, R. and Meyer, K.-J. (Eds.), IGCP Project 124.: The Northwest European Tertiary Basin, Rept. 6:87-92.

Berggren, W. A., and Hollister, C. D., 1977. Plate tectonics and paleocirculation: commotion in the ocean. In Bonin, J., and Dietz, R.S. (Eds.), The Present State of Plate Tectonics. Tectonophysics, 38:11-48.

Berggren, W. A., Kent, D. V., and Van Couvering, J. A., 1985. Neogene geochronology and chronostratigraphy. In Snelling, N. J. (Ed.), The Chronology of the Geological Record. Geol. Soc. London Mem., 10:211-260.

Berggren, W. A., and Olsson, R. K., 1986. North Atlantic Mesozoic and Cenozoic paleobiogeography. In Vogt, P. R., and Tucholke, B. E. (Eds.), The Geology of North America: The Western North Atlantic Region. Geol. Soc. Am., M:565-584.

Blanc, P., and Duplessy, J.-C., 1982. The deep-water circulation during the Neogene and the impact of the Messinian salinity crisis. DeepSea Res., 29:1391-1414.

Brown, S., and Downie, C., 1984. Dinoflagellate cyst biostratigraphy of late Paleocene and early Eocene sediments from Holes 552, 553, and 555, Leg 81, Deep Sea Drilling Project (Rockal Plateau). In Roberts, D. G., Schnitker, D., et al., Init. Repts. DSDP, 81: Washington (U.S. Govt. Printing Office), 565-579.

1985. Dinoflagellate cyst stratigraphy of Paleocene to Miocene sediments from the Goban Spur (Sites 548-550, Leg 80). In de Graciansky, P. C., Poag, C. W., et al., Init. Repts. DSDP, 80:Washington (U.S. Govt. Printing Office), 643-651.

Bujak, J. P., 1980. Dinoflagellate cysts and acritarchs from the Eocene Barton Beds of southern England. In Bujak, J. P., Downie, C., Eaton, G. L., and Williams, G. L. (Eds.), Dinoflagellate Cysts and Acritarchs from the Eocene of Southern England. Palaeontol. Assoc. Spec. Pap. Palaeontol., 24:36-91.

1984. Cenozoic dinoflagellate cysts and acritarchs from the Bering Sea and northern North Pacific, DSDP Leg 19. Micropaleontology, 30(2):180-212.

Bujak, J. P., and Davies, E. H., 1981. Neogene dinoflagellate cysts from the Hunt Dome Kopanoar M-13 well, Beaufort Sea, Canada. Bull. Can. Pet. Geol., 29(3):420-425.

Bujak, J. P., and Matsuoka, K., 1986a. Late Cenozoic dinoflagellate cyst zonation in the western and northern Pacific. In Wrenn J., et al.
(Eds.), Proc. 1st Symp. Neogene Dinofiagellate Cyst Biostratigraphy. AASP Cont. Ser., 17:7-25.

1986b. Taxonomic reallocation of Cenozoic dinoflagellate cysts from Japan and the Bering Sea. Palynology, 10:235-242.

Bujak, J. P., and Williams, G. L., 1979. Dinoflagellate diversity through time. Mar. Micropaleontol., 4:1-12.

Bujak, J. P., Downie, C., Eaton, G. L., and Williams, G. L., 1980. Taxonomy of some Eocene dinoflagellate cyst species from southern England. In Bujak, J. P., Downie, C., Eaton, G. L., and Williams, G. L. (Eds.), Dinoflagellate Cysts and Acritarchs from the Eocene of Southern England. Palaeontol. Assoc. Spec. Pap. Palaeontol., 24: 26-36; 1-100.

Châteauneuf, J.-J., 1980. Palynostratigraphie et Paléoclimatologie de l'Eocène supérieur et de l'Oligocène du Bassin de Paris. Bur. Rech. Géol. Min. Mém., 116:1-360.

Corradini, D., and Biffi, U., 1988. Etude des Dinokystes a la limite Messinien-Pliocène dans la coupe Cava Serredi, Toscane, Italie. Bull. Centres Rech. Explor.-Prod. Elf. Aquitaine, 12(1):221-236.

Costa, L. I., 1980. Neogene dinocyst stratigraphy in the northern North Sea. 5th Int. Palynol. Conf., Cambridge, 1980, p. 92. (Abstract)

Costa, L. I., and Downie, C., 1979. Cenozoic dinocyst stratigraphy of Sites 403 to 406 (Rockall Plateau), IPOD Leg 48. In Montadert, L., Roberts, D. G., et al., Init. Repts. DSDP, 48:Washington (U.S. Govt. Printing Office), 513-529.

Dale, B., 1983. Dinoflagellate resting cysts: benthic plankton. In Fryxell, G. A. (Ed.), Survival Strategies of the Algae: Cambridge (Cambridge Univ. Press), 69-136.

1985. Dinoflagellate cyst analysis of upper Quaternary sediments in core GIK 15530-4 from the Skagerrak. Nor. Geol. Tidss., 65:97-102.

de Vernal, A., 1986. Analyses palynologiques et isotopiques de sédiments de la mer Labrador et de la baie de Baffin: élements d'une climatostratigraphique du Quaternaire supérior dans l'est du Canada [Ph.D. dissert.]. Université de Montréal.

Dixon, J., McNeil, D. H., Dietrich, J. R., Bujak, J. P., and Davies, E. H., 1984. Geology and biostratigraphy of the Dome Gulf Hunt Kopanoar M-13 well, Beaufort Sea. Geol. Surv. Can. Pap., 82-13: $1-28$.

Duffield, S., and Stein, J. A., 1986a. Peridiniacean-dominated dinoflagellate cyst assemblages from the Miocene of the Gulf of Mexico shelf, offshore Louisiana. In Wrenn J., et al. (Eds.), 1st Symp. Neogene Dinoflagellate Cyst Biostratigraphy. AASP Contr. Ser., 17: $27-46$.

1986b. Biostratigraphy and taxonomy of Neogene dinoflagellate cysts in sediments from Walvis Ridge, Eastern Atlantic Ocean (Deep Sea Drilling Project, Leg 40). Palynology, 10:245-246.

Edwards, L. E., 1984a. Dinocysts of the Tertiary Piney Point and Old Church Formations, Pamunkey River area, Virginia. In Ward, L. W., and Kraft, K. (Eds.), Stratigraphy and Paleontology of the Outcropping Tertiary Beds in the Pamunkey River Region, Central Virginia Coastal Plain. Atlantic Coastal Plain Geol. Assoc. Guidebook, 124134.

1984b. Miocene dinocysts from Deep Sea Drilling Project Leg 81, Rockall Plateau, eastern North Atlantic Ocean. In Roberts, D. G., Schnitker, D., et al., Init. Repts. DSDP, 81: Washington, (U.S. Govt. Printing Office), 581-594.

1986. Late Cenozoic dinoflagellate cysts from South Carolina, U.S.A. In Wrenn, J. et al. (Eds.), 1st Symp. Neogene Dinoflagellate Cyst Biostratigraphy. AASP Contr. Ser., 17:47-58.

El Beialy, S. Y., 1988a. Palynostratigraphy of late Tertiary sediments in Kafr El-Dawar well no. 1, Nile Delta, Egypt. Rev. Micropaléontol., 30(4):249-260.

1988b. Neogene palynostratigraphy of the El-Qawasim No. 1 well. Nile Delta, Egypt. Neues Jahrb. Geol. Paläont. Montash., 8: 453-463.

Evans, C.D.R., and Hughes, M. J., 1984. The Neogene succession of the South Western Approaches, Great Britain. J. Geol. Soc. London, 141(2):315-326.

Evitt, W. R., 1984. Some techniques for preparing, manipulating and mounting dinoflagellates. J. Micropalaeontol., 3(2):11-18.

Fechner, G., and Mohr, B. A., 1986. Zur palynostratigraphischen Stellung alttertiärer Ton-Schollen in den pleistozänens Geschiabemergeln der Insel Fehmarn (Norddeutschland). Cour. Forsch.-Inst. Senckenberg, 86:295-310. 
1988. Early Eocene spores, pollen and microplankton assemblages from Fehmarn Island, Northern Germany. In Collinson, M. E. (Ed.), Plants and Their Palaeoecology Examples from the Last 80 Million Years. Tertiary Res., 9(1-4):147-168.

Goodman, D. K., 1987. Dinoflagellate cysts in ancient and modern sediments. In Taylor, F.R.J. (Ed.), The Biology of Dinoflagellates: Oxford (Blackwell Scientific), Botanical Monogr. 21:649-722.

Gradstein, F. M., and Srivastava, S. P., 1980. Aspects of Cenozoic stratigraphy and paleoceanography of the Labrador Sea and Baffin Bay. Palaeogeogr., Palaeoclimatol., Palaeoecol., 30:261-295.

Habib, D., 1971. Dinoflagellate stratigraphy across the Miocene/Pliocene boundary, Tabiano stratotype section. In Farinacci, A. (Ed.), Proc. 2nd Planktonic Conf. (Edizioni Technoscienza), Rome, 1970, 1:591-598.

Haq, B. U., Hardenbol, J., and Vail, P. R., 1987. Chronology of fluctuating sea levels since the Triassic. Science, 235:1156-1167.

Harland, R., 1977. Recent and late Quaternary (Flandrian and Devensian) dinoflagellate cysts from marine continental shelf sediments around the British lsles. Palaeontographica, Abt. B(164):87-126.

1978. Quaternary and Neogene dinoflagellate cysts. In Thusu, B. (Ed.), Distribution of Biostratigraphically Diagnostic Dinoflagellate Cysts and Miospores from the Northwest European Continental Shelf and Adjacent Areas. Inst. Kontinentalsokkelundersøkelser Publ., 100:7-17.

1979. Dinoflagellate biostratigraphy of Neogene and Quaternary sediments at Holes $400 / 400 \mathrm{~A}$ in the Bay of Biscay (Deep Sea Drilling Project Leg 48). In Montadert, L., Roberts, D. G., et al., Init. Repts. DSDP, 48: Washington (U.S. Govt. Printing Office), 531-545.

1981. Cysts of the colonial dinoflagellate Polykrikos schwartzii Bütschli 1873, (Gymnodiniales), from Recent sediments, Firth of Forth, Scotland. Palynology, 5:65-79.

1983. Distribution maps of Recent dinoflagellate cysts in bottom sediments from the North Atlantic Ocean and adjacent seas. Palaeontology, 26:321-387.

1988a. Dinoflagellates, their cysts and Quaternary stratigraphy. New Phytol., 108:111-120.

$1988 \mathrm{~b}$. Quaternary dinoflagellate cyst biostratigraphy of the North Sea. Palaeontology, 31(3):877-903.

Harland, R. and Hill, J., 1979. A reappraisal of the Cainozoic dinoflagellate cyst 'Hystrichosphaeridium' choanophorum Deflandre and Cookson, 1955. Rev. Palaeobot. Palynol., 28:37-45.

Head, M. J., Norris, G., Mudie, P., and ODP Shipboard Party, 1986. Late Miocene palynology of Site 646, ODP Leg 105, Labrador Seapreliminary results. Am. Assoc. Stratigr. Palynol. 19th Ann. Mtg., New York (Program and Abstracts), 15.

Herngreen, G.F.W., 1973. Palynology of Albian-Cenomanian strata of Borehole 1-QS-MA, State of Maranhao, Brazil. Pollen Spores, 15: 515-555.

1983. Dating Tertiary strata in seven boreholes in the Oldenzaal-Denekamp area (Twente), eastern Netherlands. Meded. Rijks Geol. Dienst, 37-3:125-153.

1987. Correlation between Miocene beds of the southeast Netherlands and Italy, based on dinoflagellate biozonation. Meded. Werkgr. Tert. Kwart. Geol., 24(1-2):32-40.

Herngreen, G.F.W., Felder, W. M., Kedves, M., and Meesen, J.P.M.T., 1986. Micropaleontology of the Maestrichtian in Borehole Bunde, The Netherlands. Rev. Palaeobot. Palynol., 48:1-70.

Hodell, D. A., Elmstrom, K. M., and Kennett, J. P., 1986. Latest Miocene benthic $\delta^{18} 0$ changes, global ice volume, sea level and the 'Messinian salinity crisis.' Nature, 320:411-414.

Holmes, R. W., 1956. The annual cycle of phytoplankton in the Labrador Sea, 1950-51. Bull. Bingham Oceanogr. Coll., XV1(1):3-44.

Hooper, P.W.P., and Weaver, P.P.E., 1987. Paleoceanographic significance of late Miocene to early Pliocene planktonic foraminifers at Deep Sea Drilling Site 609. In Ruddiman, W. F., Kidd, R. B., Thomas, E., et al., Init. Repts. DSDP, 94 (Pt. 2): Washington (U.S. Govt. Printing Office), 925-934.

Hsü, K. J., Montadert, L., Bernoulli, D., Cita, M. B., Erickson, A., Garrison, R. E., Kidd, R. B., Melières, F., Müller, C., and Wright, R., 1977. History of the Mediterranean sainity crisis. Nature, 267: 399-403.

Jan du Chêne, R., 1977. Étude palynologique du Miocène supérieur Andalou (Espagne). Rev. Espanola Micropaleontol., 9:97-114.
Jan du Chêne, R., and Londeix, L., 1988. Données nouvelles sur Achomosphaera andalousiense Jan du Chêne, 1977, kyste de Dinoflagellé fossile. Bull. Centres Rech. Explor.-Prod. Elf-Aquitaine, 12(1):237250.

Keigwin, L. D., 1987. Toward a high-resolution chronology for latest Miocene paleoceanographic events. Paleoceanography, 2(6):639-660.

Keigwin, L. D., Aubry, M. P., and Kent, D. V., 1987. North Atlantic late Miocene stable isotope stratigraphy, biostratigraphy and magnetostratigraphy. In Ruddiman, W. F., Kidd, R. B., Thomas, E., et al., Init. Repts. DSDP, 94 (Pt. 2): Washington (U.S. Govt. Printing Office), 935-964.

Kidd, R. B., and Hill, P. R., 1986. Sedimentation on Feni and Gardar sediment drifts. In Ruddiman, W. F., Kidd, R. B., Thomas, E., et al., Init. Repts. DSDP, 96: Washington (U.S. Govt. Printing Office), 1217-1243.

LeNoir, E. A., and Hart, G. F., 1986. Burdigalian (early Miocene) dinocysts from offshore Louisiana. In Wrenn, J., et al. (Eds.), Ist Symp. Neogene Dinoflagellate Cyst Biostratigraphy. AASP Contrib. Ser., 17:59-82.

Lentin, J. K, . and Williams, G. L., 1985. Fossil dinoflagellates: index to genera and species, 1985 edition. Can. Tech. Rep. Hydrogr. Ocean Sci., 60:1-451.

Manum, S. B., 1976. Dinocysts in Tertiary Norwegian-Greenland Sea sediments (Deep Sea Drilling Project Leg 38), with observations on palynomorphs and palynodebris in relation to environment. In Talwani, M., Udintsev, G., et al., Init. Repts. DSDP, 38: Washington (U.S. Govt. Printing Office), 897-919.

Manum, S. B., Boulter, M. C., Gunnarsdottir, H., Rangnes, K., and Scholze, A., in press. Palynology of the Eocene to Miocene sedimentary sequence of ODP Leg 104 (Norwegian Sea). In Eldholm, O., Thiede, J., et al., Proc. ODP, Sci. Results, 104: College Station, TX (Ocean Drilling Program).

Matsuoka, K., 1983. Late Cenozoic dinoflagellates and acritarchs in the Niigata District, central Japan. Palaeontographica, Abt. B, 187:89154.

1984. Some dinoflagellate cysts from the Nanggulan Formation in central Java, Indonesia. Trans. Proc. Palaeontol. Soc. Japan, N.S., 134:374-387.

1985a. Organic-walled dinoflagellate cysts from surface sediments of Nagasaki Bay and Senzaki Bay, West Japan. Bull. Faculty Liberal Arts, Nagasaki Univ., Nat. Sci., 25(2):21-115.

$1985 \mathrm{~b}$. Distribution of the dinoflagellate cyst in surface sediments of the Tsushima Warm Current. The Quaternary Res. (Daiyonki-Kenkyn), 24:1-12.

1985c. Cyst and thecate forms of Pyrophacus steinii (Schiller) Wall and Dale, 1971. Trans. Proc. Palaeontol. Soc. Japan, N.S., 140:240-262.

1987. Organic-walled dinoflagellate cysts from surface sediments of Akkeshi Bay and Lake Saroma, North Japan. Bull. Faculty Liberal Arts, Nagasaki Univ., Nat. Sci., 28 (1):35-123.

Matsuoka, K., Bujak, J. P., and Shimazaki, T., 1987. Late Cenozoic dinoflagellate cyst biostratigraphy from the west coast of North Japan. Micropaleontology, 33(3):214-229.

McCave, I. N., and Tucholke, B. E., 1986. Deep current-controlled sedimentation in the western North Atlantlc. In Vogt, P. R., and Tucholke, B. E. (Eds.), The Geology of North America, Vol. M: The Western North Atlantic Region. Geol. Soc. Am., 451-468.

Miller, K. G., Fairbanks, R. G., and Mountain, G. S., 1987. Tertiary oxygen isotope synthesis, sea level history, and continental margin erosion. Paleoceanography, 2:1-19.

Morgenroth, P., 1966. Neue in organischer Substanz erhaltene Mikrofossilien des Oligozäns. Neues Jahr. Geol. Paläontol. Abh., 127:112.

Morzadec-Kerfourn, M.-T., 1979. Etude des organismes. D-les kystes de dinoflagellés. Géol. Médit., 6(1):221-246.

1984. Les kystes de dinoflagellés dans les sédiments pléistocènes supérieurs et holocènes au large du delta du Rhone et de la Corse. In Bizon, J. J., and Burollet, P. F. (Eds.), Ecologie des Microorganismes en Méditerranée Occidentale "ECOMED." Rev. Pétrol. Tech., AFTP:170-183.

Mudie, P. J., 1985. Palynology of the CESAR cores. In Jackson, H. R., et al. (Eds.), Initial Geological Report on CESAR-The Canadian Expedition To Study the Alpha Ridge, Arctic Ocean. Geol. Surv. Can. Pap., 84-22(11):149-174. 
1987. Palynology and dinoflagellate biostratigraphy of Deep Sea Drilling Project Leg 94, Sites 607 and 611, North Atlantic Ocean. In Ruddiman, W. F., Kidd, R. B., Thomas, E., et al., Init. Repts. DSDP, 94 (Part 2): Washington (U.S. Govt. Printing Office), 785812.

in press. Palynology and dinocyst biostratigraphy of the late Miocene to Pleistocene, Norwegian Sea, ODP Leg 104, Sites 642 to 644. In Eldholm, O., Thiede, J., et al., Proc. ODP, Sci. Results, 104: College Station, TX (Ocean Drilling Program),

Mudie, P. J., and Short, S. K., 1985. Marine palynology of Baffin Bay. In Andrews, J. T. (Ed.), Quaternary Environments: Eastern Canadian Arctic, Baffin Bay and West Greenland: London (Allen and Unwin), 263-308.

Nilsen, T. H., 1983. Influence of the Greenland-Scotland Ridge on the geological history of the North Atlantic and Norwegian-Greenland Sea areas. In Bott, M.H.P., et al. (Eds.), Structure and Development of the Greenland-Scotland Ridge: New Methods and Concepts. NATO Conf. Ser., 1V(8): New York (Plenum Press), 457-478.

Partridge, A. D., 1978. Palynology of Late Tertiary at Site 365, Leg 40, Deep Sea Drilling Project. In Bolli, H. M., Ryan, W.B.F., et al., Init. Repts. DSDP, 40: Washington (U.S. Govt. Printing Office), 953-961.

Piasecki, S., 1980. Dinoflagellate cyst stratigraphy of the Miocene Hodde and Gram formations, Denmark. Bull. Geol. Surv. Denmark, 29: 53-76.

Piper, D.J.W., Mudie, P. J., Fader, G. B., et al., in press. Quaternary geology. In Keen, M. J., and Williams, G. L. (Eds.), Geology of Canada Series. East Coast Offshore Volume.

Powell, A. J., 1983. Miocene dinoflagellate cysts of the Piedmont Tertiary Basin, Italy [Ph.D. dissert.]. Univ. of Sheffield. [Not seen]. 1986a. Latest Palaeogene and earliest Neogene dinoflagellate cysts from the Lemme section, northwest ltaly. In Wrenn, J., et al. (Eds.), 1st Symp. Neogene Dinoflagellate Cyst Biostratigraphy. AASP Contrib. Ser., 17:83-104.

1986b. A dinoflagellate cyst biozonation for the late Oligocene to middle Miocene succession of the Langhe region, northwest Italy. In Wrenn, J., et al. (Eds.), 1st Symp. Neogene Dinoflagellate Cyst Biostratigraphy. AASP Contrib. Ser., 17:105-128.

1986c. The stratigraphic distribution of Late Miocene dinoflagellate cysts from the Castellanian superstage stratotype, northwest Italy. In Wrenn, J., et al. (Eds.), 1st Symp. Neogene Dinflagellate Cyst Biostratigraphy. AASP Contrib. Ser., 17:129-150.

1988. A preliminary investigation into the Neogene dinoflagellate cyst biostratigraphy of the British Southwestern Approaches. Bull. Centres Rech. Explor. Prod. Elf-Aquitaine, 12(1):277-311.

Rossignol, M., 1962. Analyse pollinique de sédiments marins Quaternaires en Israel. II. Sédiments pléistocènes. Pollen Spores, 4(1):121148.

1964. Hystrichosphères du Quaternaire en Méditerranée orientale, dans les sédiments pléistocènes et les boues marines actuelles. Rev. Micropaléontol., 7(2):83-99.

Sarjeant, W.A.S., 1983. A restudy of some dinoflagellate cyst holotypes in the University of Kiel collections. IV. the Oligocene and Miocene holotypes of Dorothea Maier (1959). Meyniana, 35:85-137.

Sarjeant, W.A.S., Lacalli, T., and Gaines, G., 1987. The cysts and skeletal elements of dinoflagellates: speculations on the ecological causes for their morphology and development. Micropaleontology, 33(1): 1-36.

Shackleton, N. J., and Kennett, J. P., 1975. Paleotemperature history of the Cenozoic and the initiation of Antarctic glaciation: oxygen and carbon isotope analyses in DSDP Sites 277,279 , and 281 . In Kennett, J. P., Houtz, R. E., et al., Init. Repts. DSDP, 29: Washington (U.S. Govt. Printing Office), 743-755.
Srivastava, S. P., Arthur, M., et al., 1987. Proc. ODP, Init. Repts., 105: College Station, TX (Ocean Drilling Program), 1-1917.

Stein, J. A., and Duffield, S. L., 1986. Dinoflagellate cyst assemblages related to the Neogene history of the Benguela upwelling system at Deep Sea Drilling Project Site 362 (Leg 40), Walvis Ridge, Southeastern Atlantic Ocean. Palynology, 10:259.

Stein, R., and Bleil, U., 1986. Deep-water circulation in the northeast Atlantic and climatic changes during the late Neogene (DSDP Site 141). Mar. Geol., 70:191-209.

Stover, L. E., 1977. Oligocene and early Miocene dinoflagellates from Atlantic Corehole 5/5B, Blake Plateau. AASP Contrib. Ser., 5A: 66-89.

Tappan, H., and Loeblich, A. R., Jr., 1971. Geologic history of oceanic plankton. AAPG Bull., 55:366.

1972. Fluctuating rates of protistan evolution, diversification and extinction. Proc. 24th Int. Geol. Congr. Montréal, 7:205-213.

1973. Evolution of the oceanic plankton. Earth Sci. Rev., 9: 207-240.

Truswell, E. M., Sluiter, I. R., and Harris, W. K., 1984. Palynology of the Oligocene-Miocene sequence in the Oakvale-1 corehole, western Murray Basin, South Australia. J. Austral. Geol, Geophys., 9(4): 267-295.

Turon, J.-L., and Londeix, L., 1988. Les assemblages de kystes de dinoflagellés en Méditerranée occidentale (mer d'Alboran). Mise en évidence de l'évolution des paléoenvironnements depuis le dernier maximum glaciaire. Bull. Centres Rech. Explor. Prod. Elf-Aquitaine, 12(1):313-344.

Wall, D., Dale, B., Lohman, G. P., and Smith, W. K., 1977. The environmental and climatic distribution of dinoflagellate cysts in modern marine sediments from regions in the North and South Atlantic oceans and adjacent areas. Mar. Micropaleontol., 2:121-200.

Williams, D. B., 1971. The occurrence of dinoflagellates in marine sediments. In Funnel, B. M., and Riedel, W. R. (Eds.), The Micropalaeontology of Oceans. Proc. Symp. Micropalaeontol. Mar. Bottom Sediments, Cambridge, 1967, 231-243.

Williams, G. L., 1978. Palynological biostratigraphy, Deep Sea Drilling Project, Sites 367 and 370. In Lancelot, Y., Seibold, E., et al., Init. Repts. DSDP, 41: Washington (U.S. Govt. Printing Office), 783815.

Williams, G. L., and Brideaux, W. W., 1975. Palynologic analyses of upper Mesozoic and Cenozoic rocks of the Grand Banks, Atlantic continental margin. Geol. Surv. Can. Bull., 236:1-163.

Williams, G. L., and Bujak, J. P., 1977a. Distribution patterns of some North Atlantic Cenozoic dinoflagellate cysts. Mar. Micropaleontol., 2:223-233.

1977b. Cenozoic palynostratigraphy of offshore eastern Canada. AASP Contrib. Ser., 5A:14-47.

Wrenn, J. H., and Damassa, S. P., 1988. Tuberculodinium vancampoae: a curious reflection of its former self. AASP Ann. Mtg. (Houston, Tx). Program and Abstracts.

Wrenn, J. H., and Kokinos, J. P., 1986. Preliminary comments on Miocene through Pleistocene dinoflagellate cysts from De Soto Canyon, Gulf of Mexico. In Wrenn, J., et al., (Eds.), 1st Symp. Neogene Dinoflagellate Cyst Biostratigraphy. AASP Contrib. Ser., 17:169-225.

Wrenn, J. H., and Satchell, L. S., 1988. Cenozoic palynostratigraphy of Exxon core hole 32-45 from the West Florida carbonate platform, Gulf of Mexico: integration with a seismic stratigraphic model. AASP Ann. Mtg. (Houston, Tx). Program and Abstracts.

Date of initial receipt: 7 January 1988

Date of acceptance: 21 October 1988

Ms 105B-135 


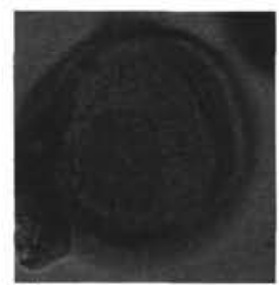

1

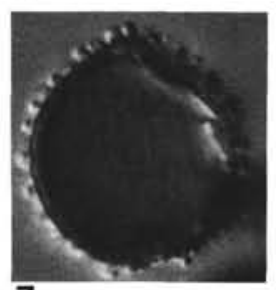

7

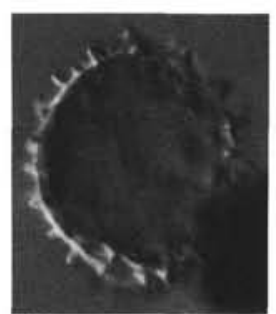

13

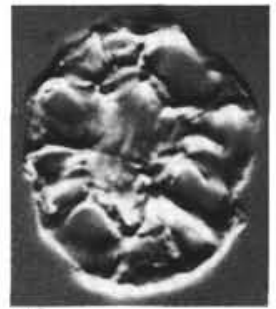

19

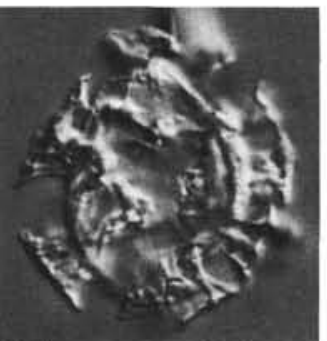

25

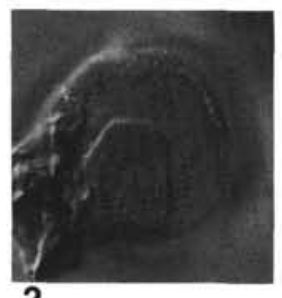

2

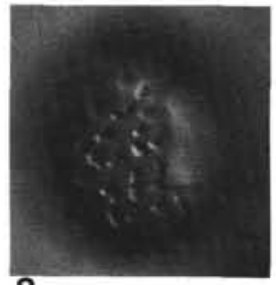

8

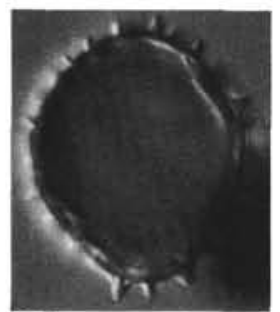

14

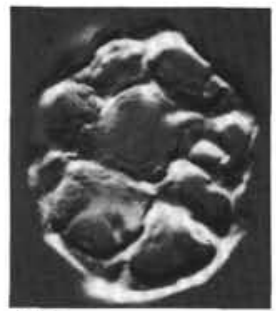

20

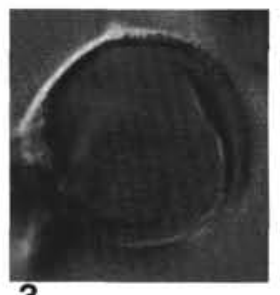

3

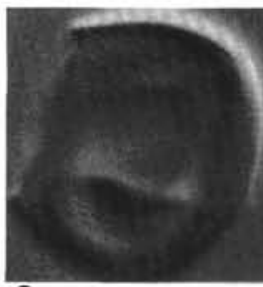

9

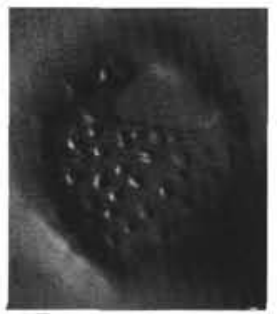

15

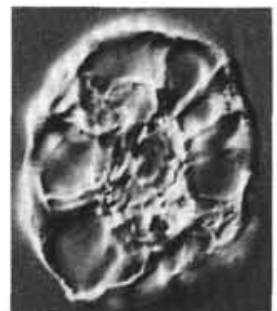

21

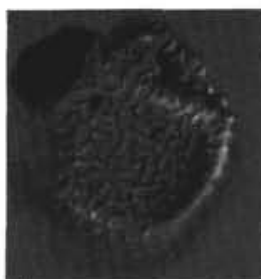

4

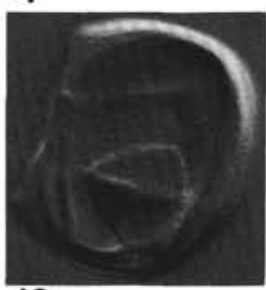

10

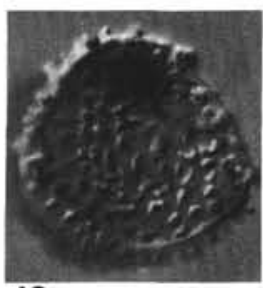

16

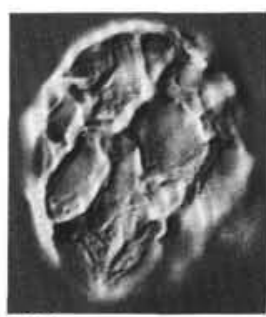

22

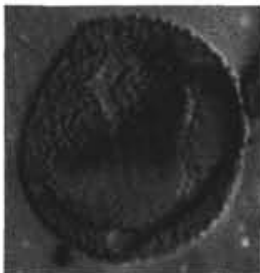

5

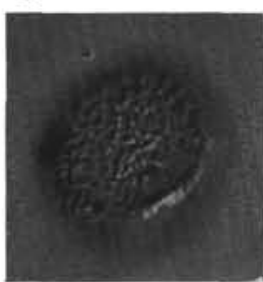

11

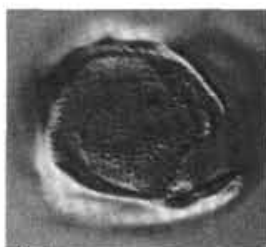

17

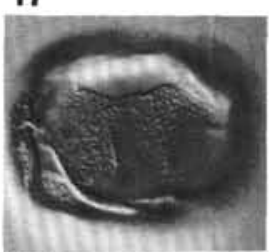

23

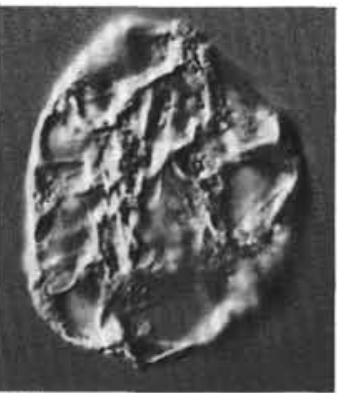

27

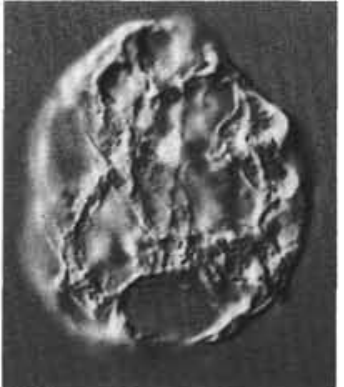

28

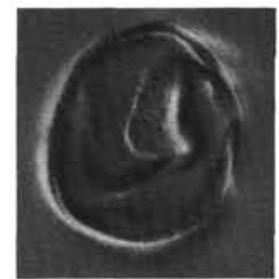

6

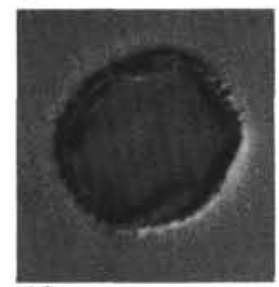

12

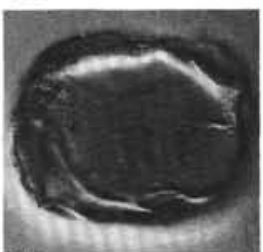

18

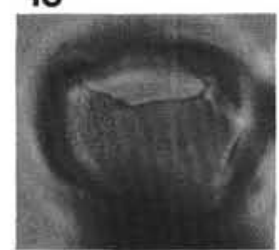

24

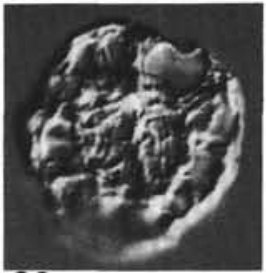

29

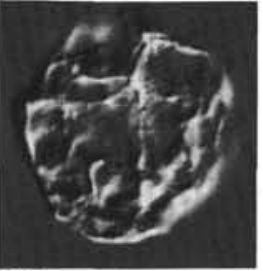

30

Plate 1. (Fig. 1, 24, BF; Figs. 2-23, 25-30, IC) 1-6, 9-12, 17, 18, 23, 24. Batiacasphaera/Cerebrocysta? Group A (4-6,11,12,17,18,23,24, vent. views of $4,11,17$, vent. surface, $5,6,23,24$, dors. surface, 12,18 , med. focus. 1-3, dors. view of dors. surface. 9,10 , lat. views of upper surface, higher and lower foci, respectively). 1-3. Sample 105-646-66X-2, 20-23 cm (1) F18/0, dia., 29 $\mu \mathrm{m}$. 4. Sample 105-646-60X, CC (1) Q8/2, dia., 29 $\mu \mathrm{m}$. 5. Sample 105-646-69X, CC (5-8 cm) (1) C12/0, dia., $30 \mu \mathrm{m}$. 6. Sample 105-646-80X-2, 2-4 cm (1) N33/0, dia., 29 $\mu \mathrm{m}$. 9,10. Sample 105-646-80X-2, 2$4 \mathrm{~cm}$ (1) U28/3, dia., $32 \mu \mathrm{m}$. 11, 12. Sample 105-646-65X-3, 101-104 cm (1) T32/0, dia. 23 $\mu \mathrm{m} .17,18,23$. Sample 646-51X-2, 21-26 cm (1) Q42/4, dia. $34 \mu \mathrm{m}$. 24, Sample 646-80X-2, 2-4 cm (1) $028 / 1$, dia. $31 \mu \mathrm{m}$. 7, 8, 16. cf. Operculodinium sp. of Piasecki (7,8, vent. view; 7, med. focus; 8, dors. surface; 16, antapical? view of upper surface) 7,8, Sample 646-76X, CC (6) S37/3, max. dia. (excl. ornament) $27 \mu \mathrm{m}$. 16, Sample 105-646-80X, CC (1) U13/0, max. dia. (excl. ornament), $30 \mu \mathrm{m}$. 13-15. Pyxidiella? sp. 1 (13-15, vent. view of, 13,14 med. focus, 15 , dors. surface). 13-15. Sample 105-646-80X-2, 2-4 cm (1) S19/4, max. dia. (excl. ornament), $31 \mu \mathrm{m}$. 19-22, 27-30. Acritarch sp 2. (20,22,28,30, upper surface; 19,21,27,29, med. focus) 19,20. Sample 105-646-78X, CC (1-3 cm) (5) K52/0, max. dia., $32 \mu \mathrm{m}$. 21,22. Sample 105-646-78X, CC (1-3 cm) (5) M47/4, max. dia., 34 $\mu$ m. 27,28. Sample 105-646-78X, CC (1-3 cm)(5) Q23/0, max. dia., $40 \mu \mathrm{m}$. 29,30. Sample 105-646-78X, CC (1-3 cm) (5) N35/3, max. dia., 28 $\mu \mathrm{m}$. 25,26. Labyrinthodinium truncatum (25,26, vent. views of; 25 , vent. surface; 26 , dors. surface) 25 , Sample $105-646-80 \mathrm{X}-2,2-4 \mathrm{~cm}$ (1) M47/0, dia. (incl. processes), $34 \mu \mathrm{m} ; 26$, Sample 105-646-80X-2, 2-4 cm (1) N15/0, dia. (incl. processes), $35 \mu \mathrm{m}$. 


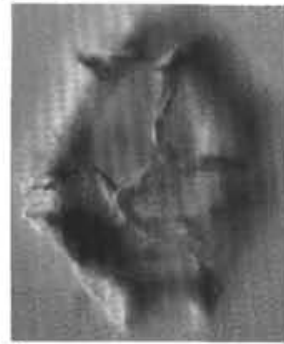

1

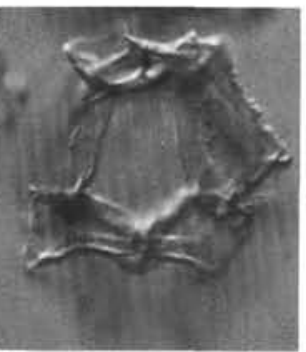

7

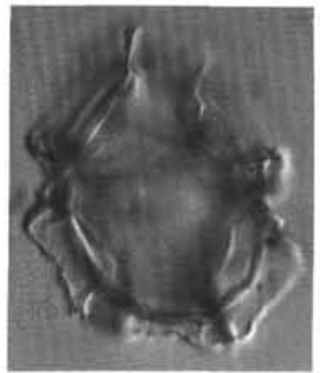

12

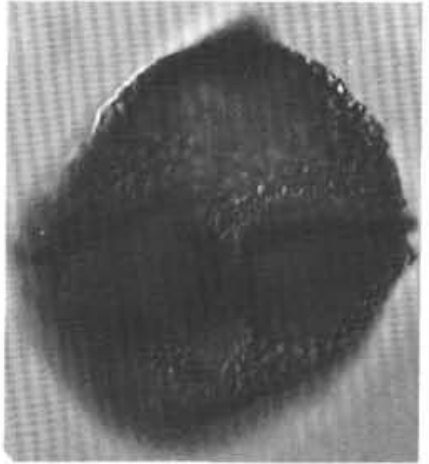

17

2

8

13
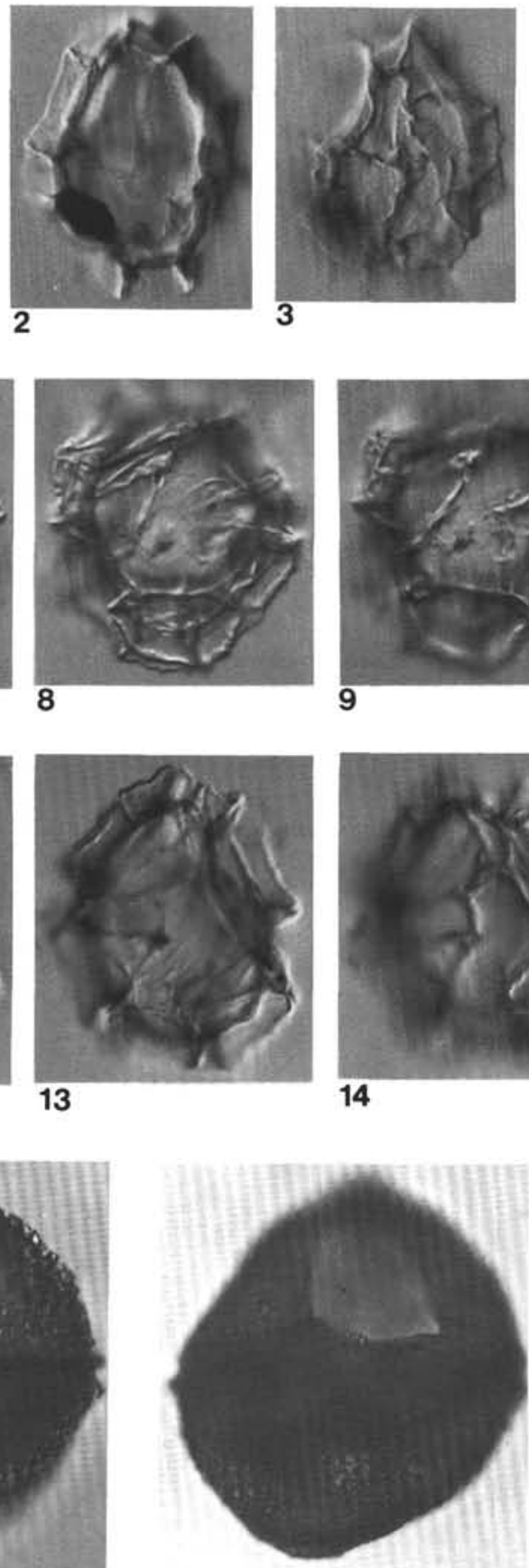

18

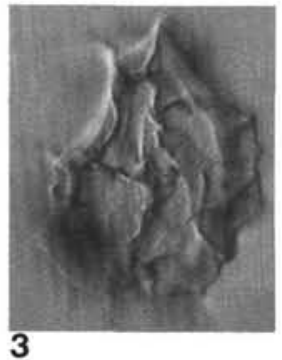

9

14
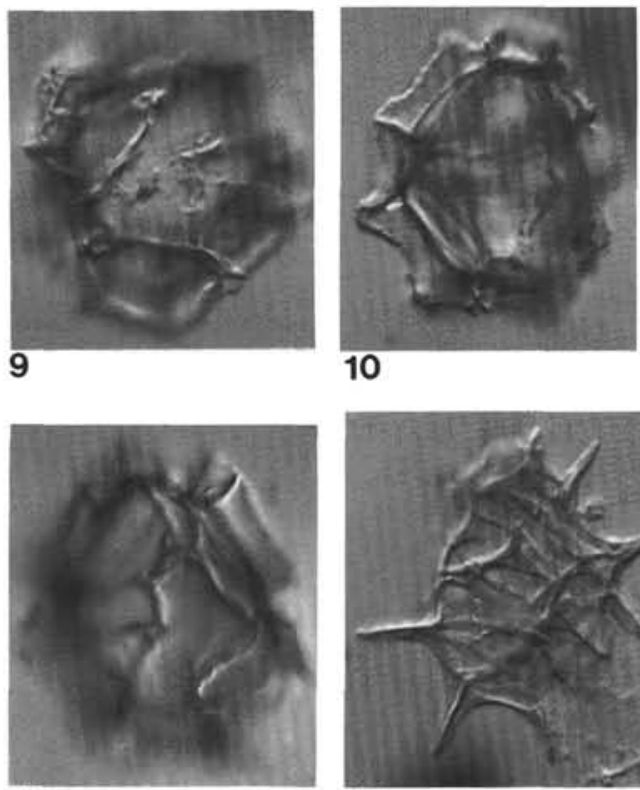

10

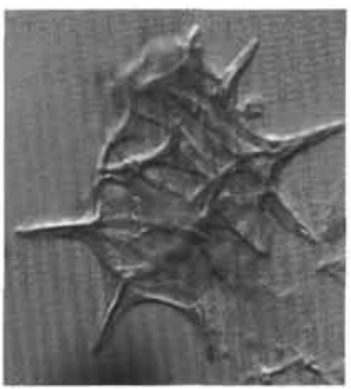

15

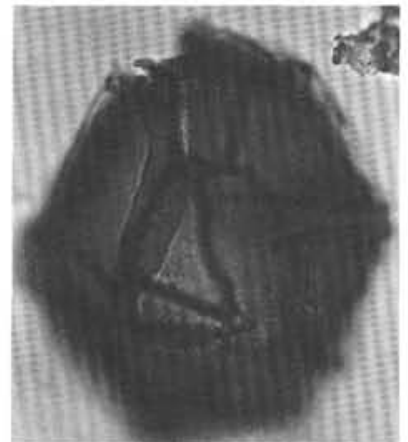

19

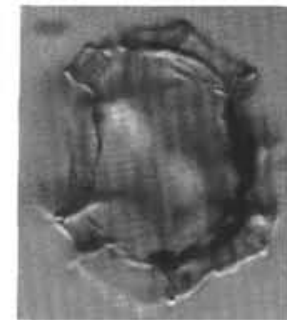

5
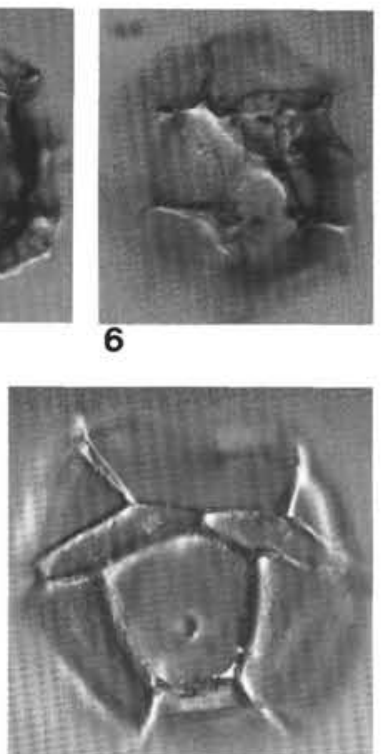

11

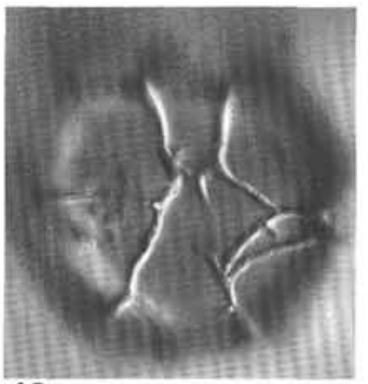

16

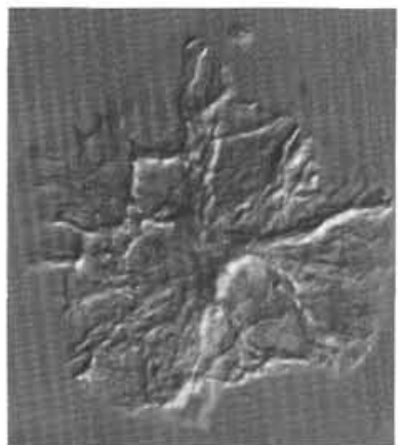

20

Plate 2. (Figs. 1-17, $20 \mathrm{IC}$; 18, $19 \mathrm{BF)}$ 1-6. Impagidinium paradoxum (1-6, vent. views of 3,6, vent. surface, 1 dors. surface, $2,4,5$ intermediate foci). 1-3. Sample 105-646-63X-3, 26-29 cm (1) L15/4, length (central body), $34 \mu \mathrm{m}$. 4-6. Sample 105-646-50X-1, 131-135 cm (1) S30/2, length (central body), $32 \mu \mathrm{m}$. 7-10, 12-14. Impagidinium sp. 1 (7-9,12-14, dors. views of; 7, dors. surface; 8,9,13,14, vent. surfaces; 12 , intermediate focus. 10, left? lat. view of intermediate focus) $7-9$. Sample 105-646-71X-2, 125-127 cm (1) 042/0, body length, $33 \mu \mathrm{m}$. 10. Sample 105-646-73X-1, 61-64 cm (1) $\mathrm{K} 33 / 0$, body length, $31 \mu \mathrm{m}$. 12-14. Sample $105-646-73 \mathrm{X}-1,61-64 \mathrm{~cm}$ (1) K14/2, body length, $33 \mu \mathrm{m}$. 15. Impagidinium sp. cf. I. aculeatum. 15 . Sample 105-646-80X-2, 2-4 cm (1) S28/2, body length, $33 \mu \mathrm{m}$. 11, 16. Impagidinium patulum (11,16, dors. views of; 11, dors. surface; 16, vent. surface). 11, 16. Sample 105-646-69X, CC, 5-8 cm (1) Q33/3, dia., $58 \mu \mathrm{m}$. 17, 18. Emslandia sp. 1 (vent. view of; 17, vent. surface; 18, dors. surface). 17, 18. Sample 105-646-65X-3, 101-104 cm (1) U14/2, length, $72 \mu \mathrm{m}$. 19. Impagidinium sp. 2 (vent. view of vent. surface). 19. Sample 105646-78X, CC (1-3 cm) (5) U45/1, max. dia., $88 \mu \mathrm{m}$. 20. Impagidinium? pallidum. 20. Sample 105-646-67X, CC (1) 028/2, dia. (incl. crests), $51 \mu \mathrm{m}$. 


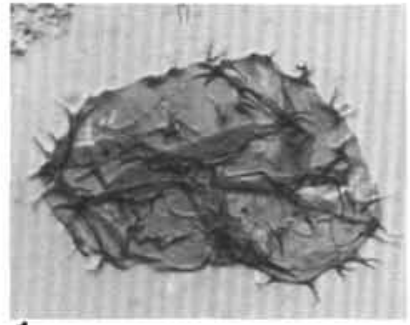

1

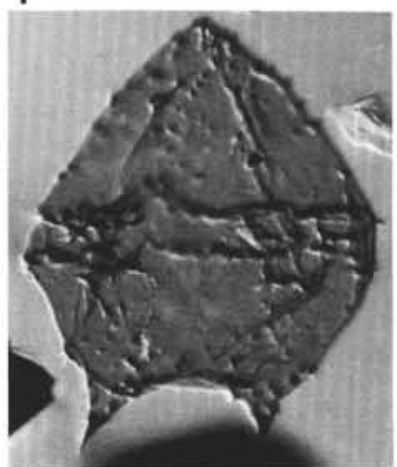

5

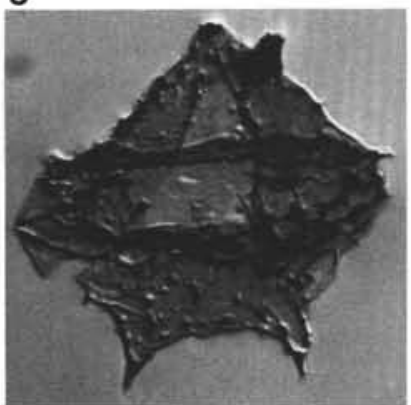

8

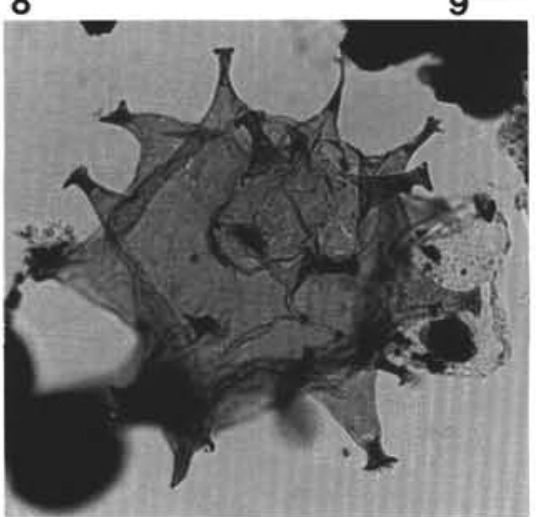

12

2
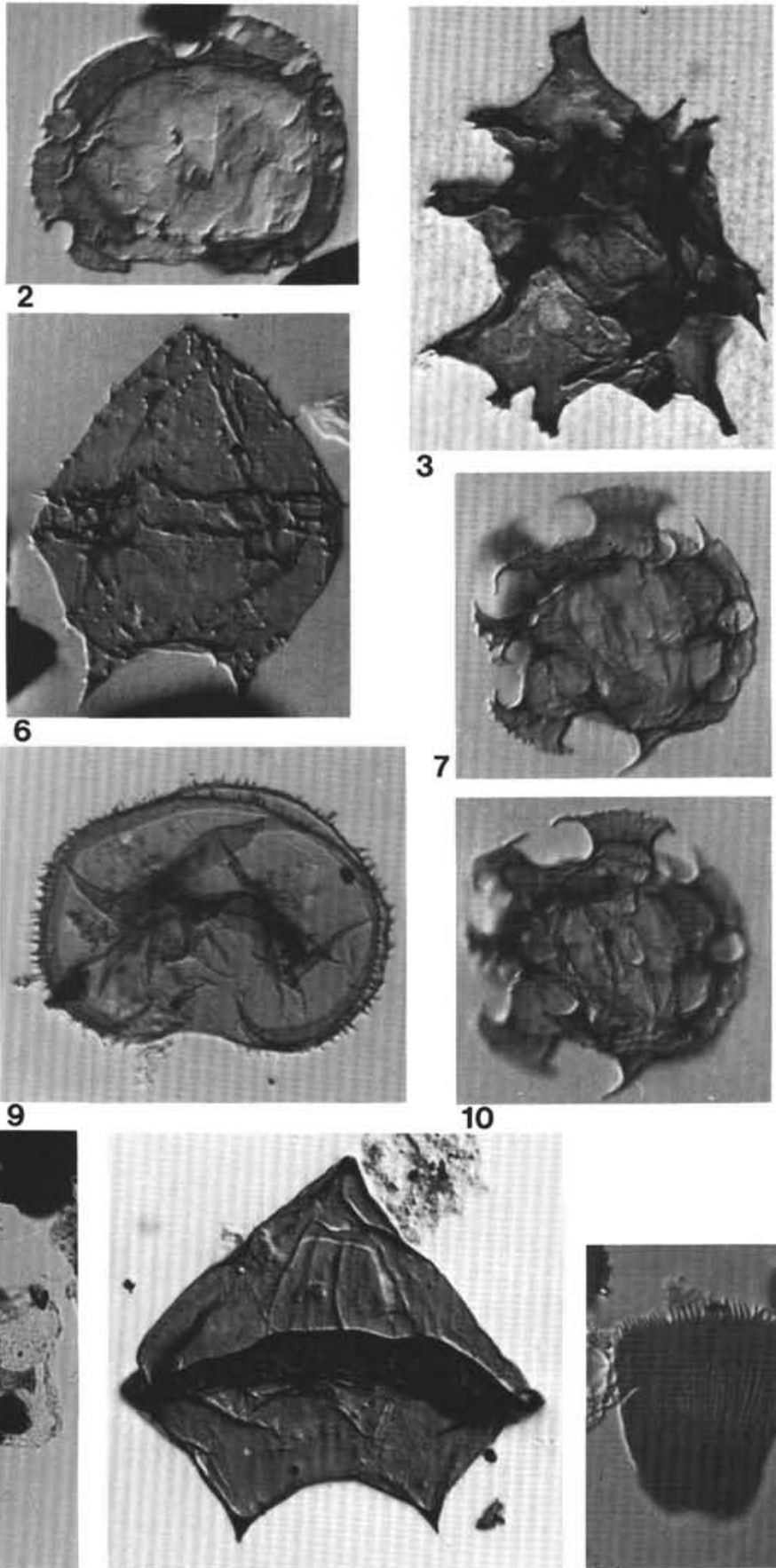

13
3
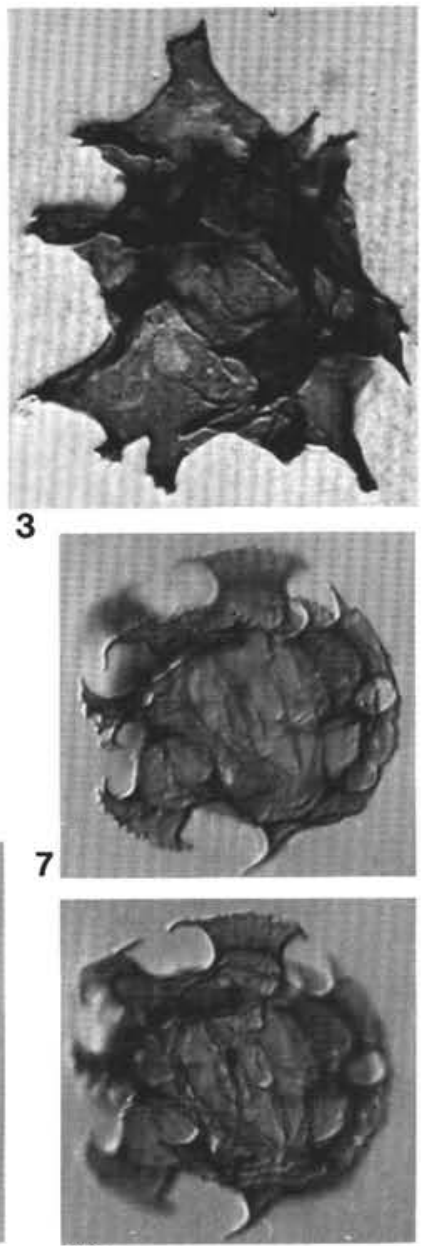

10

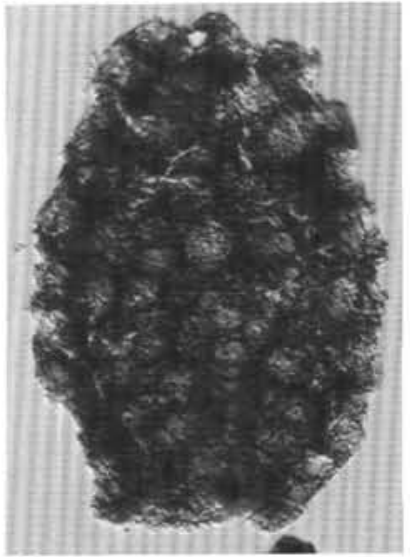

4

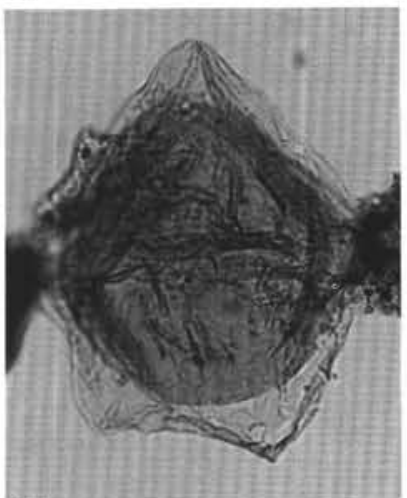

11

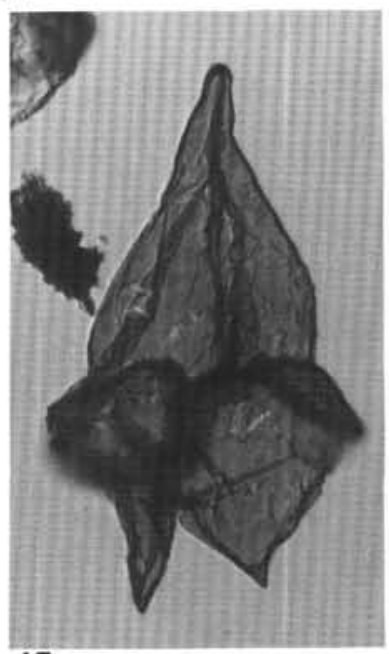

15

Plate 3. (Figs. 1-10, 12-15, IC; Fig. 11, BF) 1. Xandarodinium variabile? 1. Sample 105-646-63X-3, 26-29 cm (1) X46/2, max. dia. $45 \mu \mathrm{m}$ (excl. processes). 2, 7, 8, Selenopemphix sp. 1. 2, Sample 105-646-67X-3, 50-53 cm (2) V28/2, max. dia., $42 \mu \mathrm{m}$ (excl. processes). 7, 8, Sample 105-64667X-3, 50-53 cm (2) C30/2, max. dia., $39 \mu \mathrm{m}$ (excl. processes). 3, 12. Xandarodinium xanthum. 3, Sample 105-646-80X, CC (1) E38/1, max. dia., $69 \mu \mathrm{m}$ (incl. processes). 12, Sample 105-646-80X, CC (1) N13/2, max. dia., $66 \mu \mathrm{m}$ (incl. processes). 4. Polykrikos? sp. (equatorial view). 4, Sample 105-646-61X-1, 123-126 cm (1) F27/0, length, $106 \mu \mathrm{m}$. 5, 6, 8. Lejeunecysta sp. cf. L. tenella $(5,6,8$, dors. views of; 5 , vent. surface; 6,8, dors. surface). 5, 6, Sample 105-646-62X-2, 139-141 cm (1) M13/4, length, $55 \mu \mathrm{m}$. 8, Sample 105-646-62X-2, 139-141 cm (1) T50/2, length, $47 \mu \mathrm{m}$. 9. Selenopemphix sp. 2. 9, Sample 105-646-62X-3, 37-39 cm (2a) M35/2, max. dia., $51 \mu \mathrm{m}$ (excl. processes). 11. Deflandrea? sp. 1. 11, Sample 105-646$61 \mathrm{X}-1,123-126 \mathrm{~cm}$ (1)M23/1, periphragm length, $59 \mu \mathrm{m}$. 13, 15. Lejeunecysta spp. (13, dorsal view of dors. surface; 15 , lat. view of upper surface). 13, Sample 105-646-51X, CC (1) L20/1, length, $54 \mu \mathrm{m}$. 15. Sample 105-646-50X-1, 131-135 cm (1) P24/3, length, $101 \mu \mathrm{m}$. 14. Incertae sedis 1. 14. Sample $105-646-78 \mathrm{X}, \mathrm{CC}(1-3 \mathrm{~cm})(1) \mathrm{Q} 28 / 3$, length, $29 \mu \mathrm{m}$. 


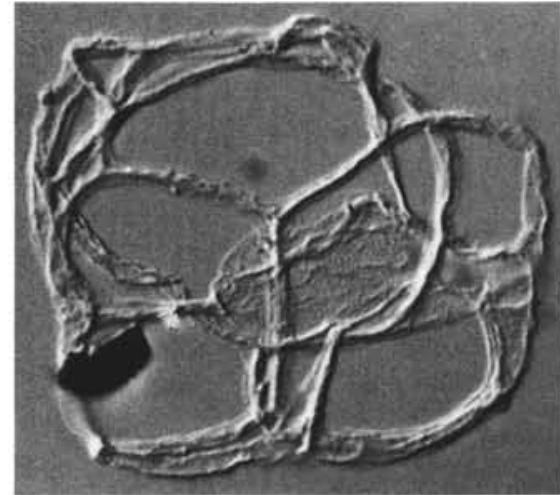

1

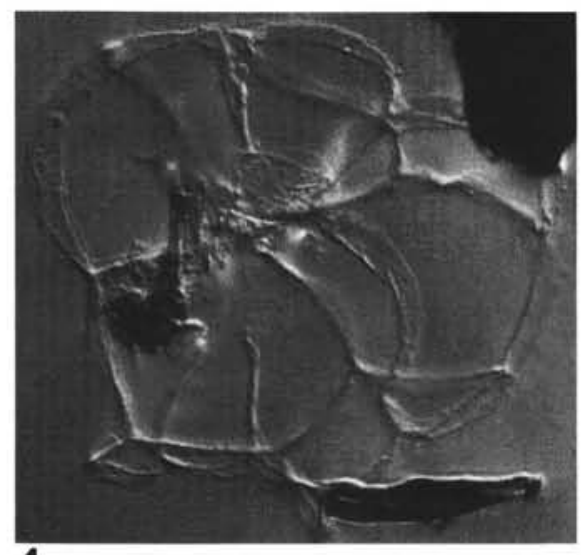

4

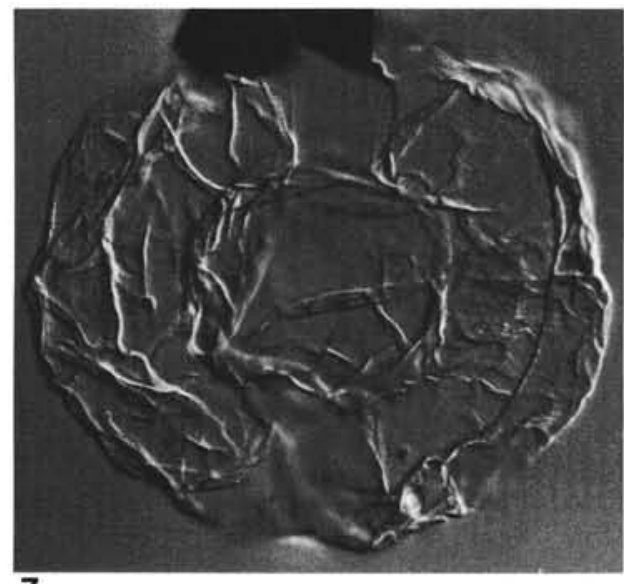

7

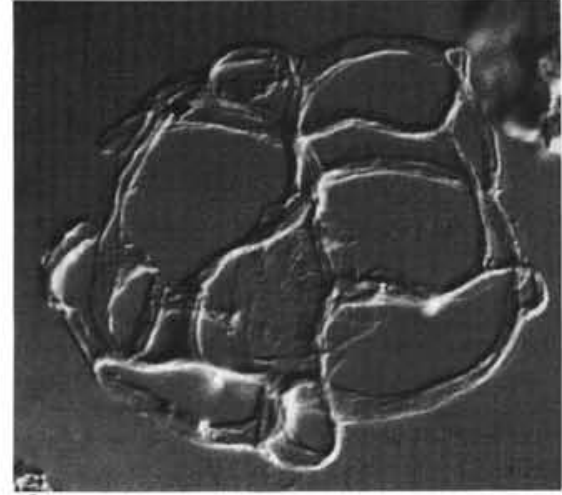

2

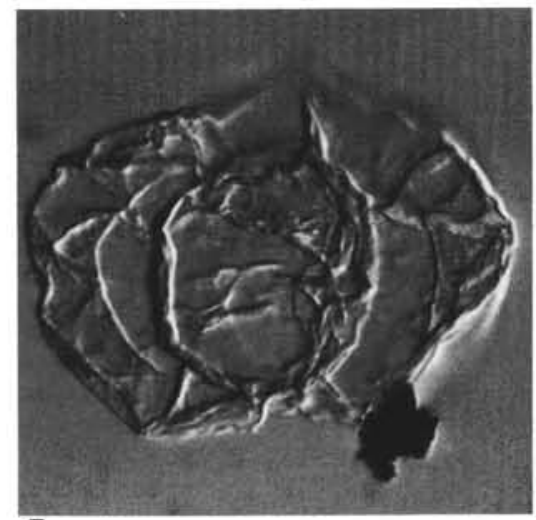

5

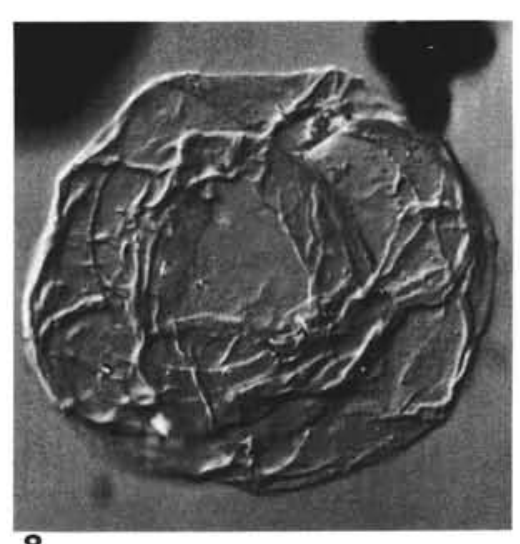

8

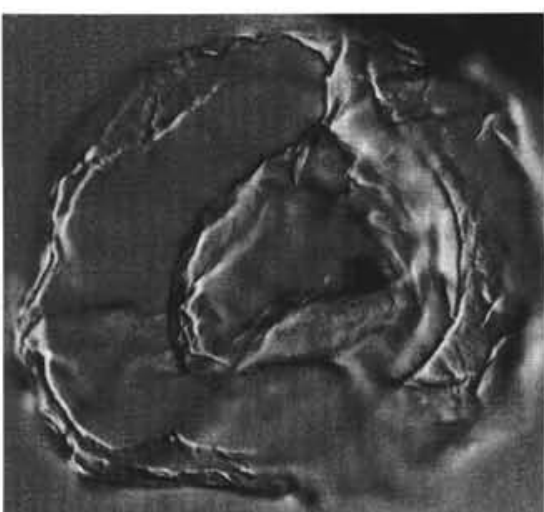

3

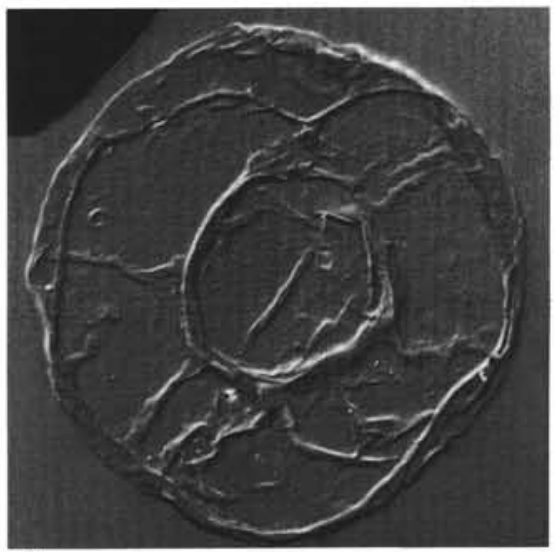

6

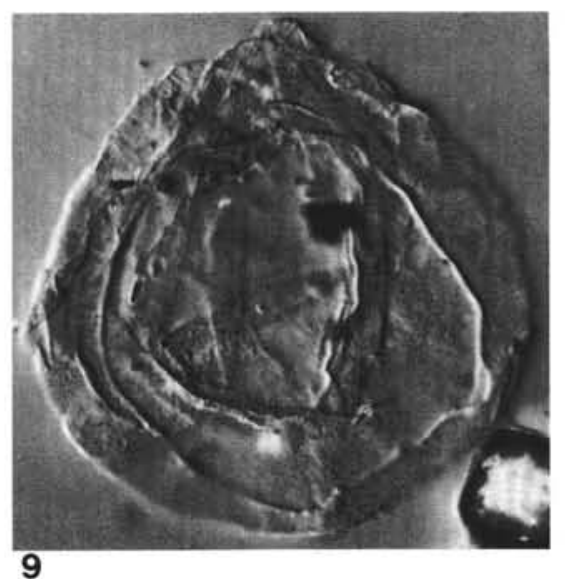

Plate 4. (All Figs. IC). 1, 2, 4. Gen. et sp. indet. 1, Sample 105-646-72X-2, 90-92 cm (1) 043/1, max. dia., 63 $\mu \mathrm{m}, 2$, Sample 105-646-72X-2, 90$92 \mathrm{~cm}$ (1) G37/1, max. dia., $73 \mu \mathrm{m}$. 4, Sample 105-646-72X-2, 90-92 cm (1) Y19/0, max. dia., 78 $\mu \mathrm{m} . \quad 3,5$, 7, 8, 9. Invertocysta spp. 3, Sample 105-646-76X, CC (1) P45/0, max. dia., $83 \mu \mathrm{m}$. 5, Sample 105-646-80X-2, 2-4 cm (1) H29/2, max. dia., $58 \mu \mathrm{m}$. 7, Sample 105-646-76X, CC (6) J42/ 0, max. dia., $86 \mu \mathrm{m}$. 8, Sample 105-646-80X-2, 2-4 cm (1) P47/2, max. dia., $57 \mu \mathrm{m}$. 9. Sample 105-646-66X-2, 20-23 cm (1) W47/2, max. dia., 62 $\mu \mathrm{m}$. 6. Invertocysta lacrymosa. 6, Sample 105-646-80X-2, 2-4 cm (1) D25/3, max. dia., $75 \mu \mathrm{m}$. 

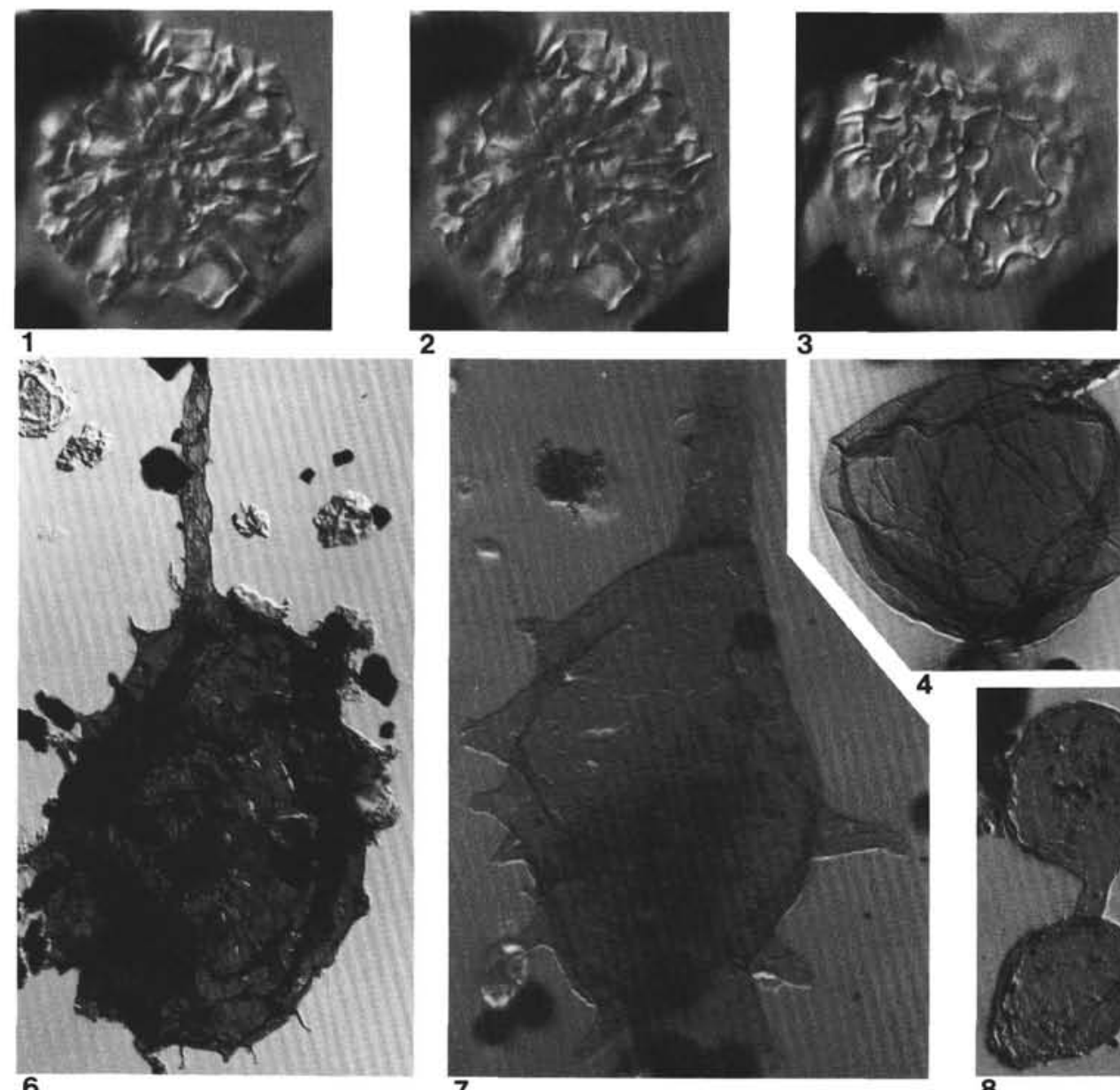

2

3

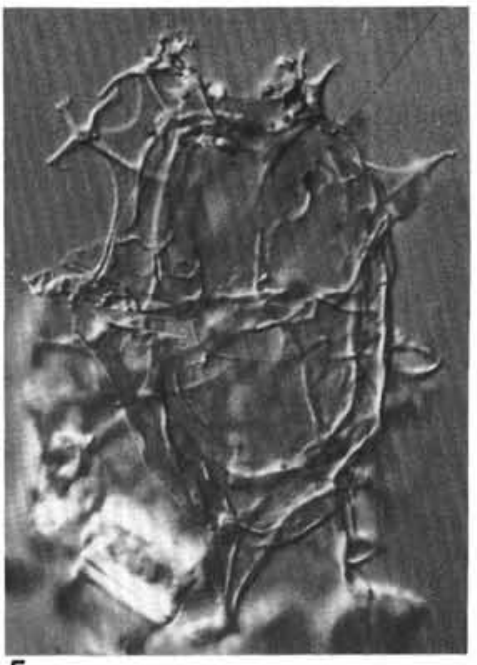

5

6

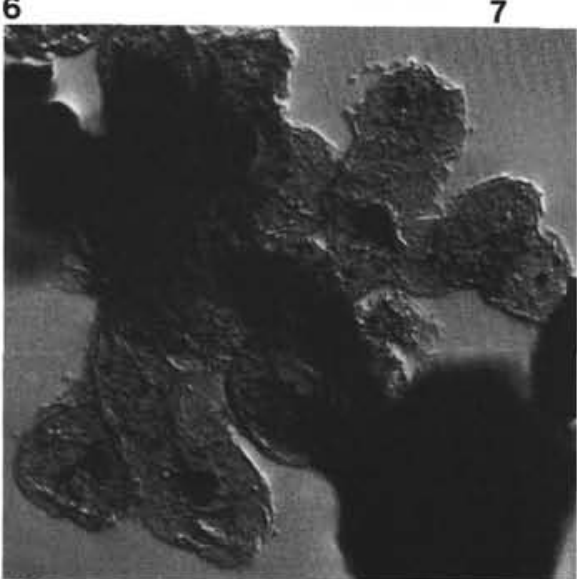

10
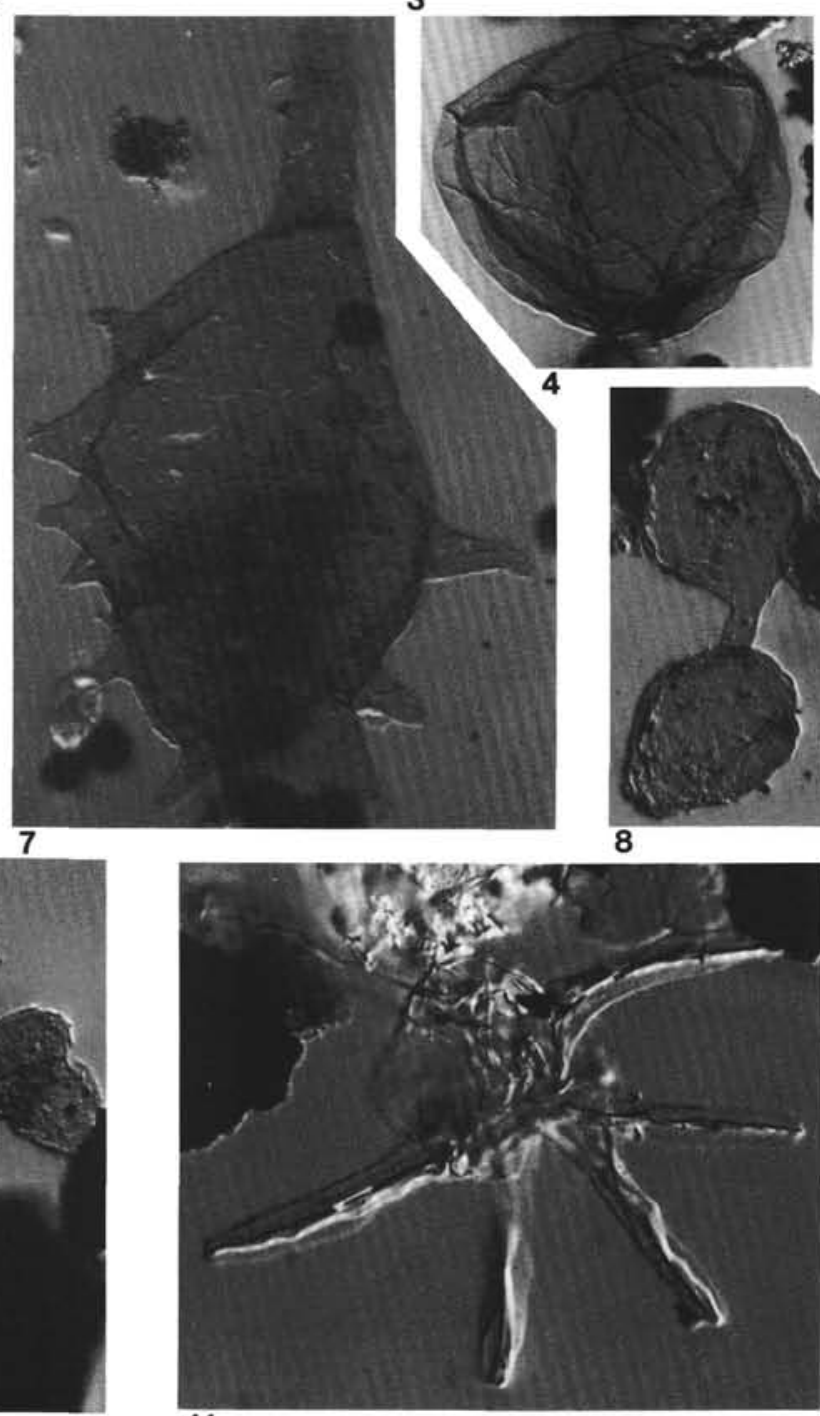

11

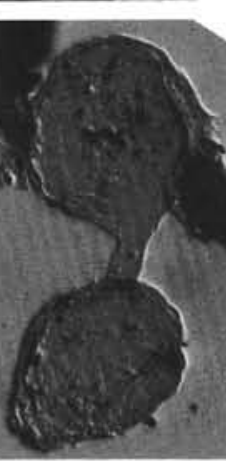

8

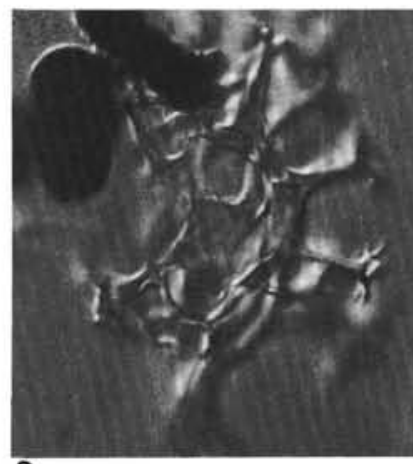

9

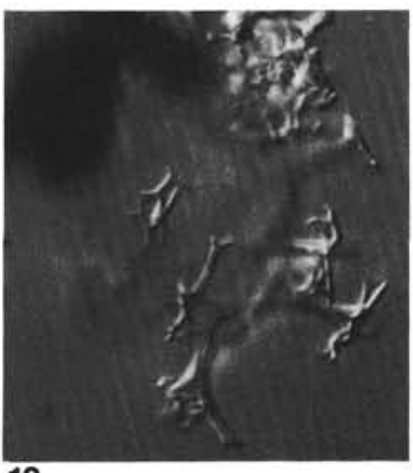

12

Plate 5 (All figures IC). 1-3. Nematosphaeropsis sp. A of Wrenn and Kokinos, 1986. 1-3, Sample 105-646-66X-2, 20-23 cm (1) M45/4, max. dia., $34 \mu \mathrm{m}$ (incl. processes). 4. Incertae sedis sp. 3. 4, Sample 105-646-59X, CC (1) N12/3, max. dia., $40 \mu \mathrm{m}$. 5. Spiniferites sp. cf. S. ellipsoideus (split focus). 5, Sample 105-646-50X-1, 131-135 cm (1) M24/2, body length, $59 \mu \mathrm{m}$. 6, 7. Forma C of Wrenn and Kokinos, 1986. 6, Sample 105646-50X-1, 131-135 cm (1) L 53/0, length, $417 \mu \mathrm{m}$. 7, Sample 105-646-80X, CC (2) M19/3, length, $240 \mu \mathrm{m}$. 8, 10. Incertae sedis sp. 2. 8, Sample 105-646-50X, CC (1) S37/0, length, $106 \mu \mathrm{m}$. 10, Sample 105-646-61X-1, 123-126 cm. (1) H46/0, length, $148 \mu \mathrm{m}$. 9, 12. Achomosphaera andalousiensis (9, upper surface; 12, higher focus) 9, 12, Sample 105-646-76X, CC (6) 013/0, body length, $33 \mu \mathrm{m}$. 11. Incertae sedis sp. 1 of Edwards, 1984. 11, Sample 105-646-80X-2, 2-4 cm (1) T37/4, length, $99 \mu \mathrm{m}$ (incl. processes). 

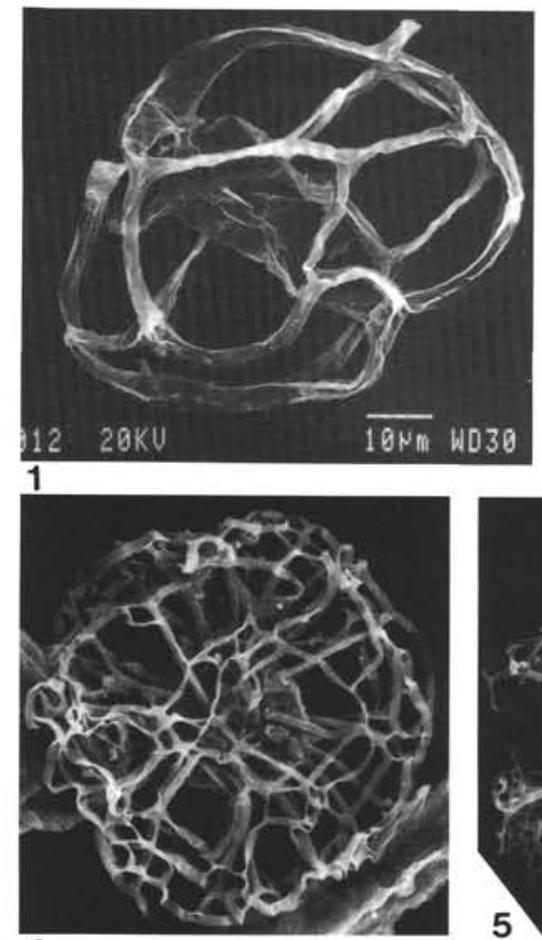

4

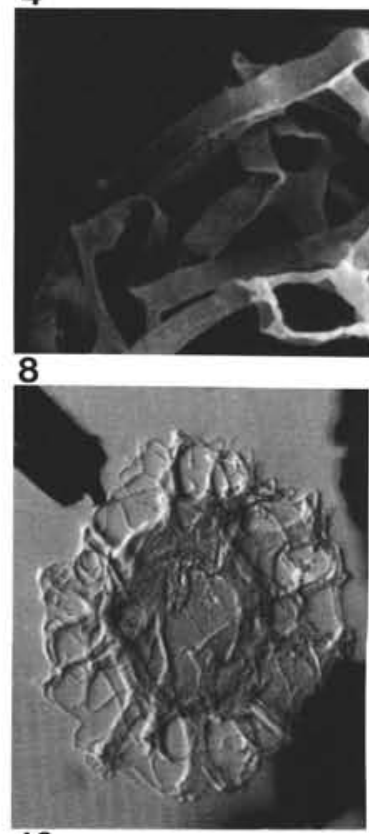

12

13
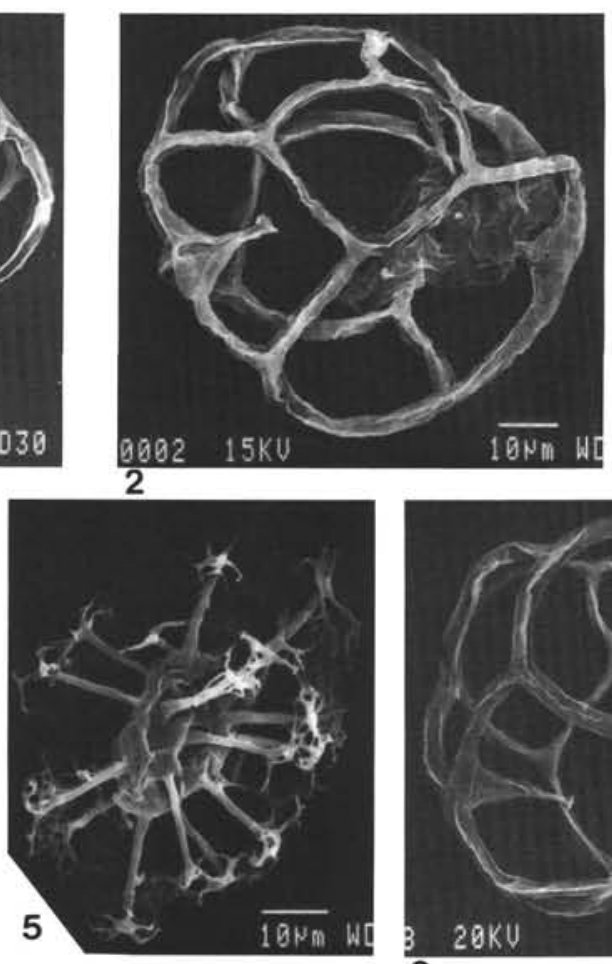

6
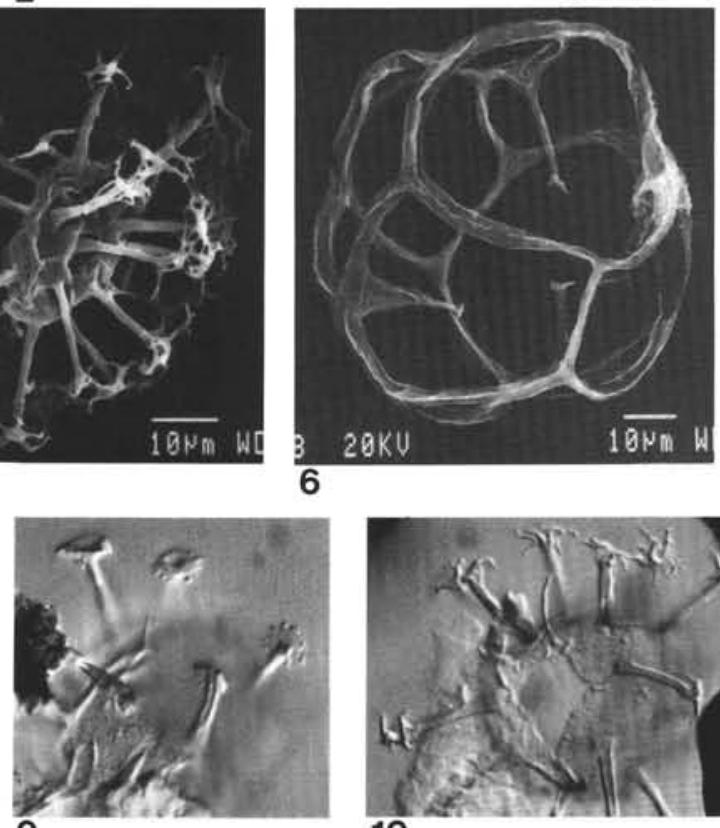

9

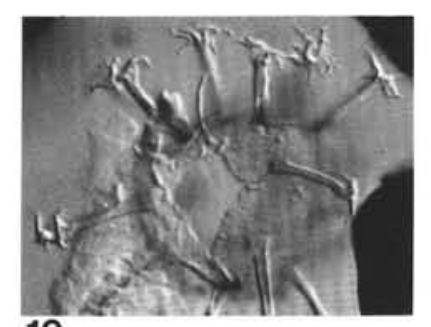

10

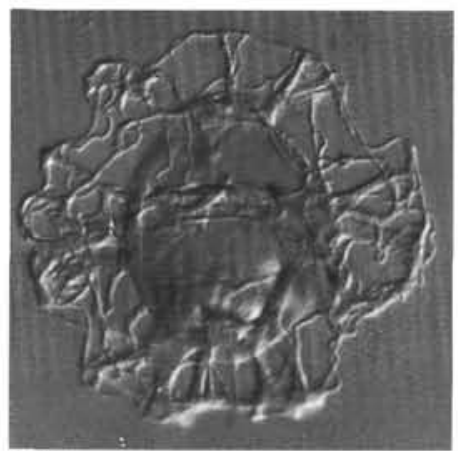

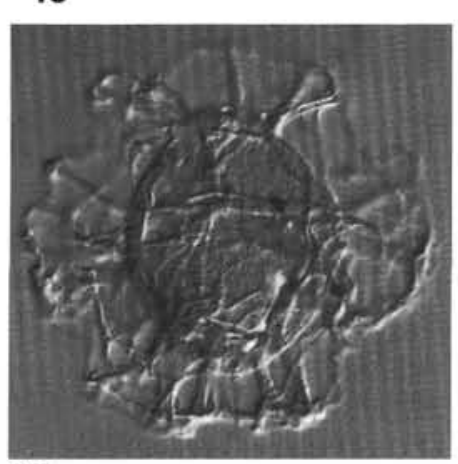

14
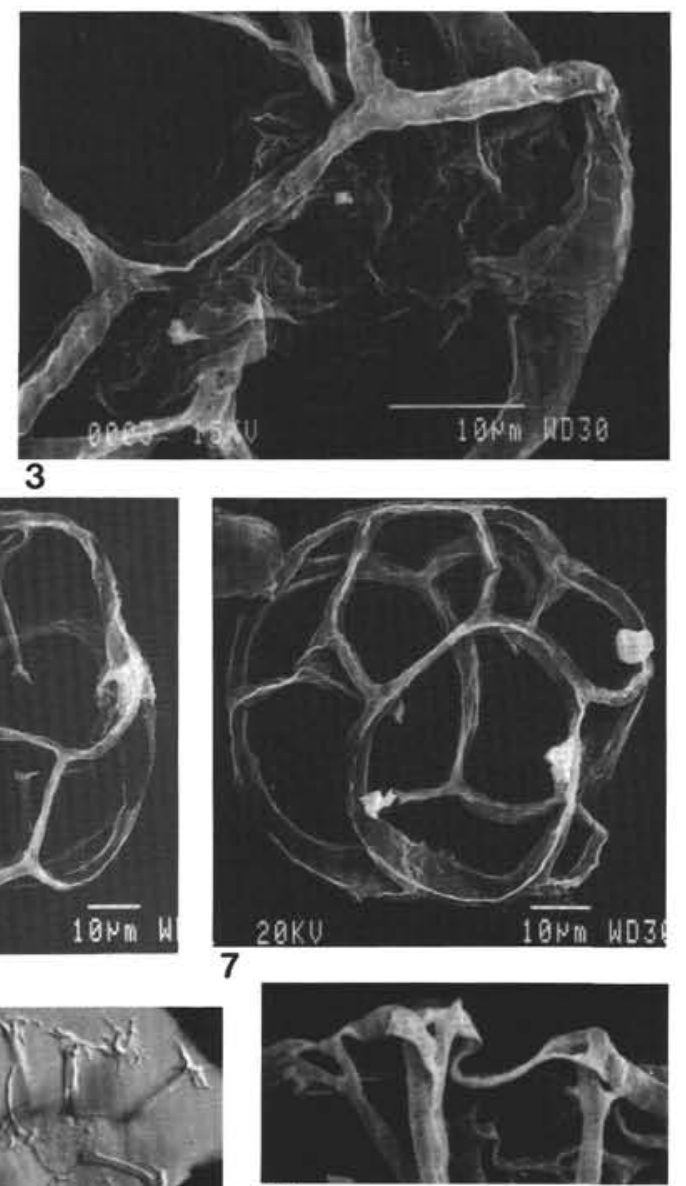

11

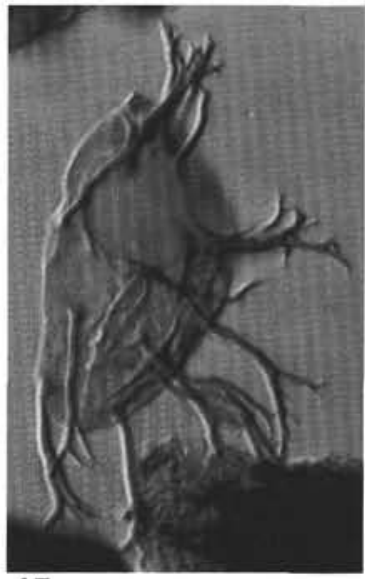

15

Plate 6. (Figs. 1-8, 11 SEM; Figs. 9, 10, 12-15, IC). 1-3, 6, 7. Gen. et sp. indet. 1, Sample 105-646-73X-1, 61-64 cm, stub 2. 2, Sample 105-646-

$73 \mathrm{X}-1,61-64 \mathrm{~cm}$, stub 1. 3, Sample 105-646-73X-1, 61-64 cm, stub 1 (higher mag. specimen in Fig. 2). 6, Sample 105-646-73X-1, 61-64 cm, stub 1. 7, Sample 105-646-73X-1, 61-64 cm, stub 2. 4, 8, 11. Nematosphaeropsis lemniscata. 4, Sample 105-646-62X-2, 139-141 cm stub 2, X1100. 8, Sample 105-646-62X-2, 139-141 cm, stub 2, X2330 (higher mag. specimen in Fig. 4). 11, Sample 105-646A-62X-2, 139-141 cm, stub 2, X2330. 5. Reticulatosphaera actinocoronata. 5, Sample 105-646-73X-1, 61-64 cm, stub 1. 9,10. Melitasphaeridium choanophorum (10, oblique apical view, upper surface) 9, Sample 105-646-80X-2, 2-4 cm (1) 035/3, body dia., $38 \mu \mathrm{m}$. 10, Sample 105-646-66X-2, 20-23 cm (1) P18/0, body dia., 30 $\mu \mathrm{m}$. $12-14$. Nematosphaeropsis sp. 1 (12, midfocus; 13, 14, upper surface of; 13 trabeculae; 14 , central body). 12, Sample 105-646-69X, CC, 5-8 cm (1) U26/2, body dia., $27 \mu \mathrm{m}$. 13,14, Sample 105-646-78X, CC (1-3 cm) (5) K28/0, body dia., $37 \mu \mathrm{m} . \quad$ 15. Surculosphaeridium sp. of Duffield and Stein, 1986a. 15 , Sample 105-646-80X-2, 2-4 cm (1) L17/1, body length, $41 \mu \mathrm{m}$. 


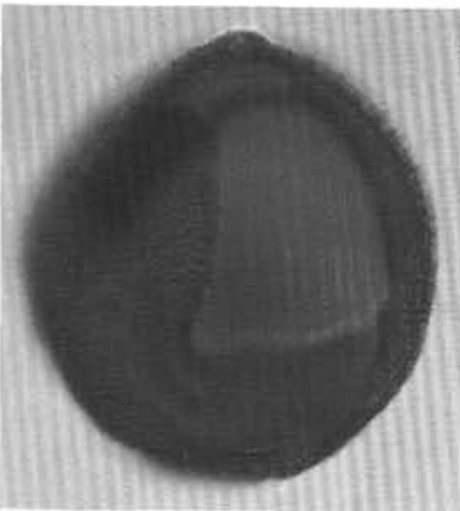

1

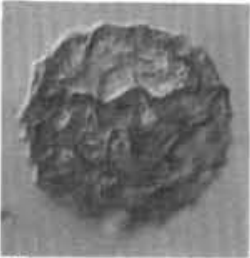

4

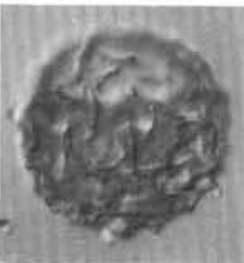

8

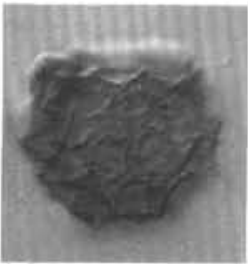

9

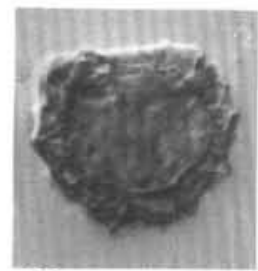

12

\section{5}

10

13

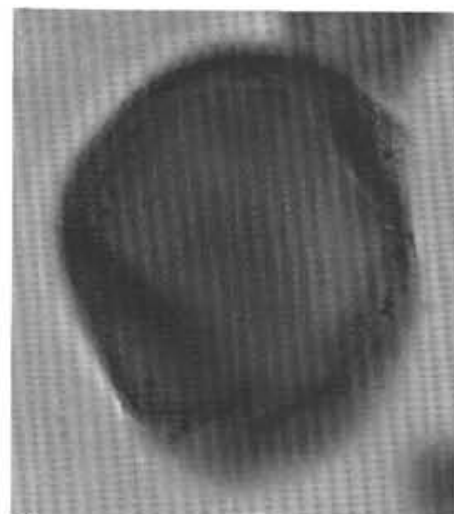

2
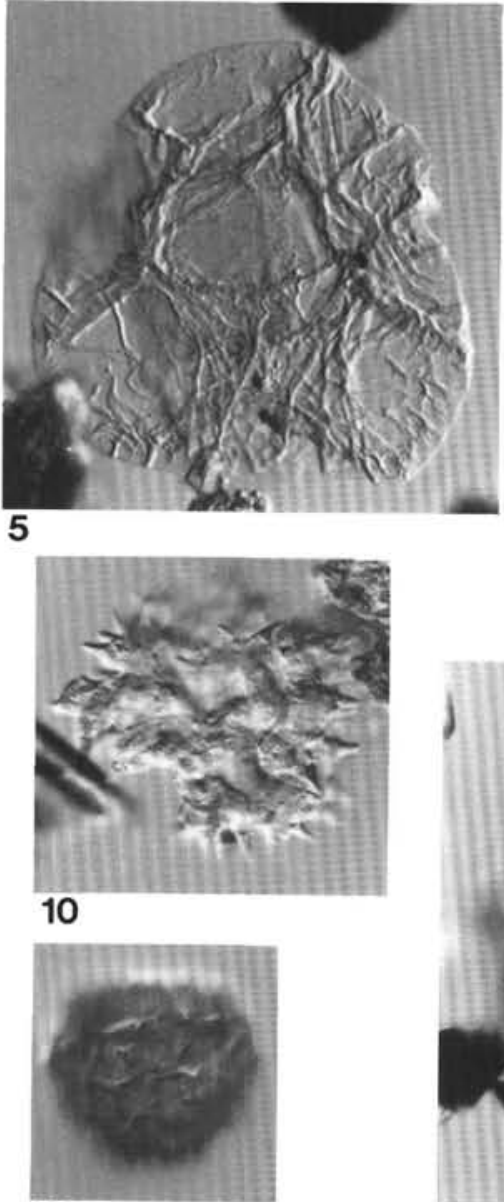

6

14

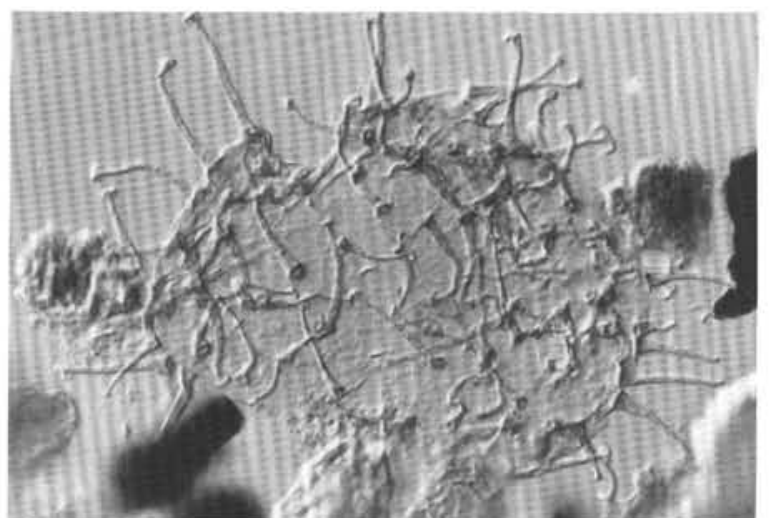

3
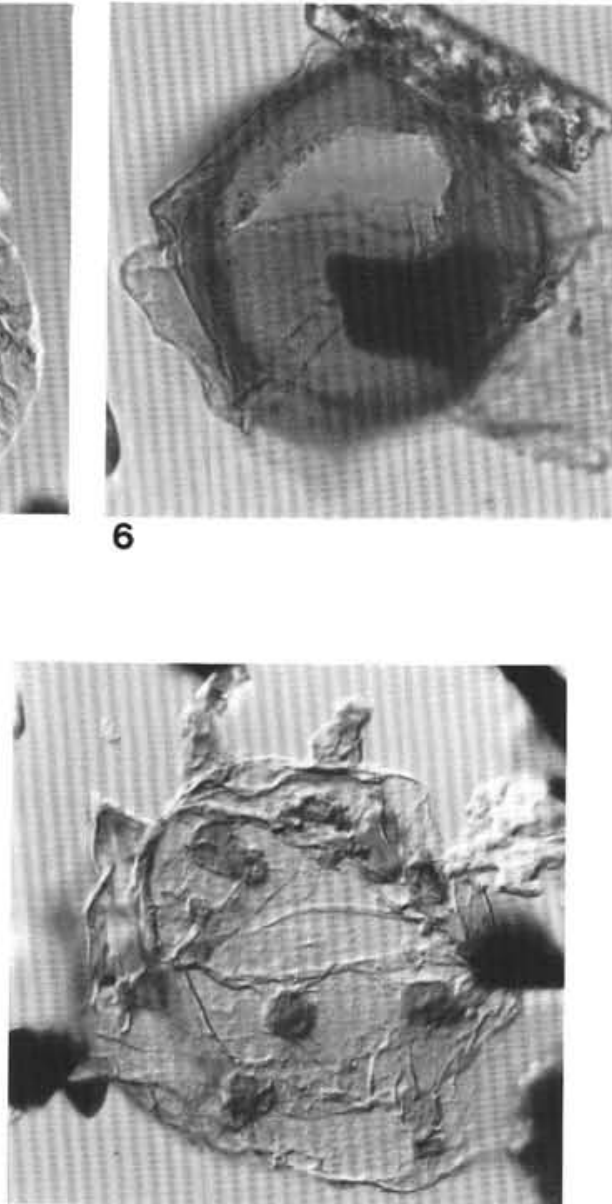

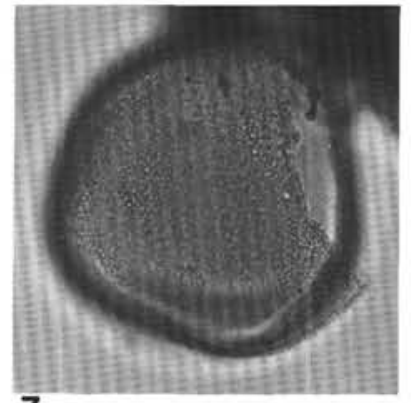

7

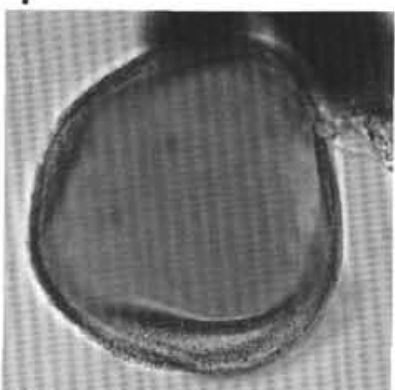

11

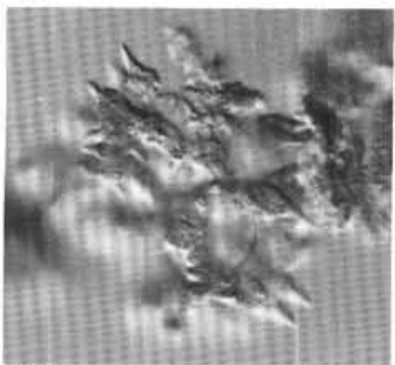

15

Plate 7. (Figs. 1, 3-5, 8-10, 12-15, IC; Figs. 2,6,7,11, BF). 1,7,11. cf. Filisphaera sp. A (1, dors. view of dors. surface; 7,11, subvent. view at; 11, midfocus; 7, of subdors. surface). 1, Sample 105-646-51X-2, 21-26 cm (1) S42/0, max. dia., $63 \mu \mathrm{m} .7,11$, Sample 105-646-51X-2, 21-26 cm (1) dia., $55 \mu \mathrm{m}$. 2. Filisphaera sp. cf. F. filifera (vent. view at midfocus). 2, Sample 105-646-51X, CC (1) dia., $53 \mu \mathrm{m}$. 3. Polysphaeridium? sp. 1. 3, Sample 105-646-51X-2, 21-26 cm (1) V12/2, max. body dia., $87 \mu \mathrm{m}$. 4, 8, 9, 12, 13. Acritarch sp. 1 (4,9, high focus; 12, midfocus; 8,13, low focus). 4,8, Sample 105-646-51X-2, 21-26 cm (1) W46/2, dia. $26 \mu \mathrm{m} .9,12,13$, Sample 105-646-51X-2, 21-26 cm (1) U43/2, dia., $25 \mu \mathrm{m}$. 6. Pentadinium laticinctum laticinctum (dors. view of dors. surface), 6, Sample 105-646-66X-2, 20-23 cm (1) N39/1, pericyst max. dia., $76 \mu \mathrm{m}$. 10,15 . Lophate compositaceous pollen (10, upper surface; 15, higher focus). 10,15, Sample 105-646-71X-2, 125-127 cm (1) H26/4, dia. (incl. spines), 38 $\mu \mathrm{m}$. 14. Tuberculodinium vancampoae (orientation uncertain). 14, Sample 105-646-66X-2, 20-23 cm (1) M37/2, pericyst dia., $80 \mu \mathrm{m}$. 